Prepared in cooperation with the Indiana Department of Environmental Management

\title{
Water Quality in Indiana: Trends in Concentrations of Selected Nutrients, Metals, and lons in Streams, 2000-10
}

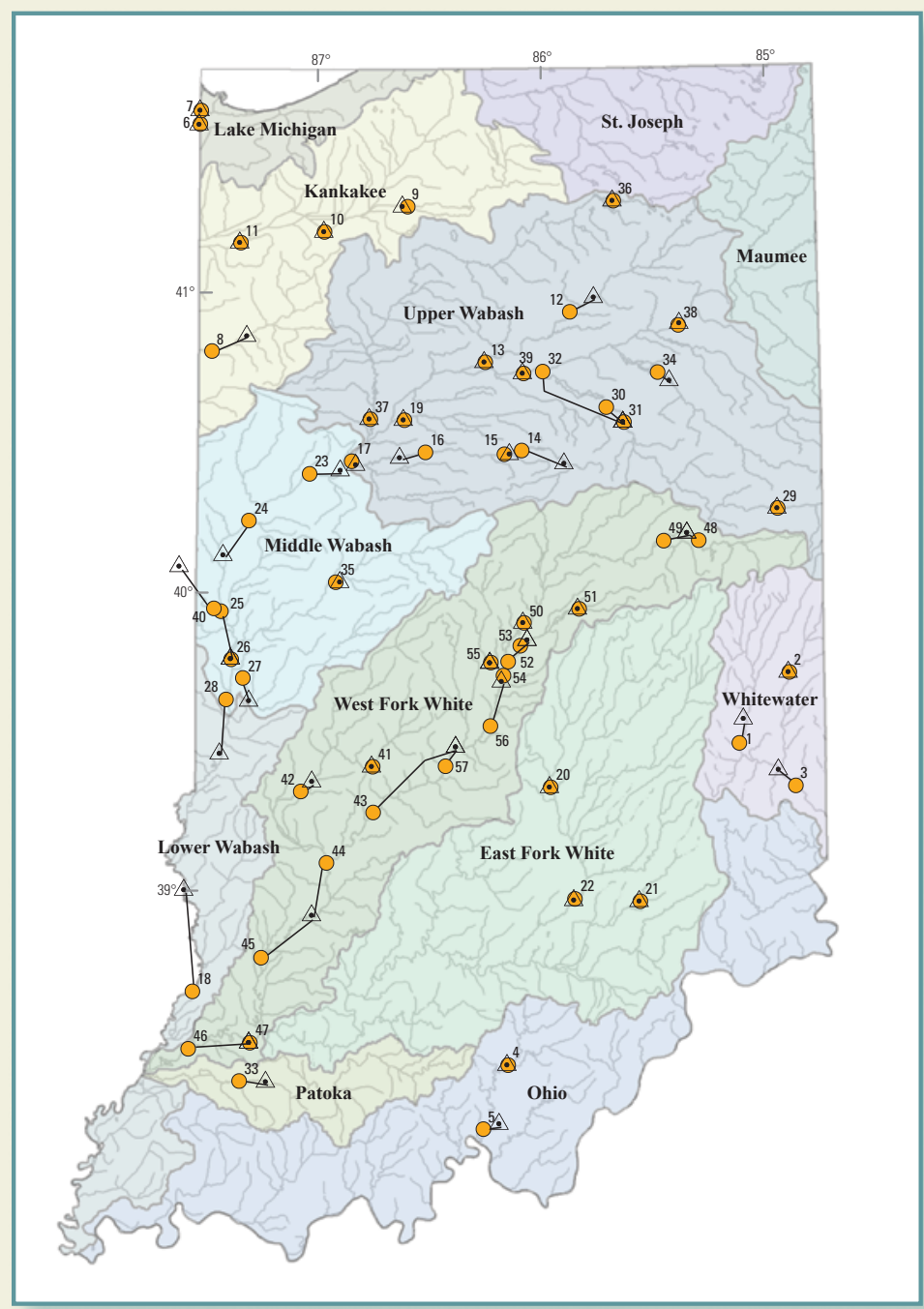

Scientific Investigations Report 2014-5205 
Cover figure. Selected Indiana Fixed Station Monitoring Program stream sites and associated streamgages used in this study. 


\section{Water Quality in Indiana: \\ Trends in Concentrations of Selected Nutrients, Metals, and lons in Streams, 2000-10}

By Martin R. Risch, Aubrey R. Bunch, Aldo V. Vecchia, Jeffrey D. Martin, and Nancy T. Baker

Prepared in cooperation with the Indiana Department of Environmental Management

Scientific Investigations Report 2014-5205 


\title{
U.S. Department of the Interior SALLY JEWELL, Secretary
}

\section{U.S. Geological Survey Suzette M. Kimball, Acting Director}

\author{
U.S. Geological Survey, Reston, Virginia: 2014
}

For more information on the USGS - the Federal source for science about the Earth, its natural and living resources, natural hazards, and the environment, visit http://www.usgs.gov or call 1-888-ASK-USGS.

For an overview of USGS information products, including maps, imagery, and publications, visit http://www.usgs.gov/pubprod

To order this and other USGS information products, visit http://store.usgs.gov

Any use of trade, firm, or product names is for descriptive purposes only and does not imply endorsement by the U.S. Government.

Although this information product, for the most part, is in the public domain, it also may contain copyrighted materials as noted in the text. Permission to reproduce copyrighted items must be secured from the copyright owner.

Suggested citation:

Risch, M.R., Bunch, A.R., Vecchia, A.V., Martin, J.D., and Baker, N.T., 2014, Water quality in Indiana-Trends in concentrations of selected nutrients, metals, and ions in streams, 2000-10: U.S. Geological Survey Scientific Investigations Report 2014-5205, 47 p., http://dx.doi.org/10.3133/sir20145205.

ISSN 2328-031X (print) ISSN 2328-0328 (online) 


\section{Contents}

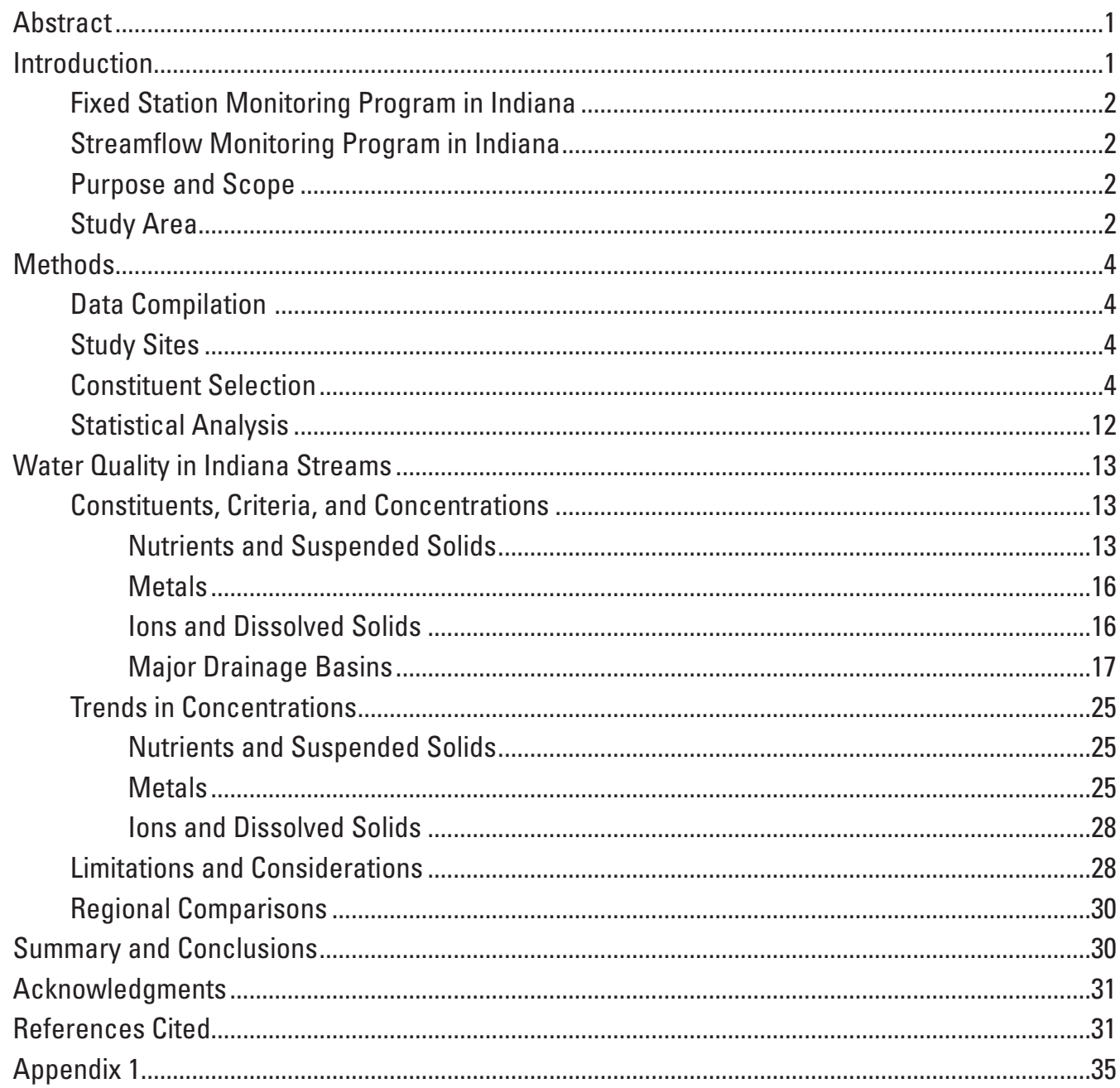

\section{Figures}

1. Map showing major rivers in Indiana................................................................................

2. Map showing all Indiana Fixed Station Monitoring Program sites and stream sites selected for use in this study......................................................................

3. Map showing selected Indiana Fixed Station Monitoring Program stream sites and associated streamgages used in this study. ........................................8

4. Map showing Indiana Fixed Station Monitoring Program stream sites used in this study with diagram of upstream watershed size..........................................

5. Map showing aggregate ecoregions in Indiana..........................................................15

6. Boxplots showing distributions of concentrations for each constituent, by drainage basin. $A$, Nutrients and suspended solids. $B$, Metals.

$C$, lons and dissolved solids. 


\section{Figures (continued)}

7. Maps showing sites with significant trends in concentrations of nutrients and suspended solids, 2000-10. A, Nitrate. B, Organic nitrogen.

$C$, Phosphorus. $D$, Suspended solids

8. Maps showing sites with significant trends in concentrations of metals, 2000-10. A, Copper. $B$, Iron. C, Lead. D, Zinc

9. Maps showing sites with significant trends in concentrations of ions and dissolved solids, 2000-10. $A$, Chloride. $B$, Sulfate. $C$, Hardness.

$D$, Dissolved solids.

1-1. Map and diagrams showing significant and non-significant trends in nitrate at 57 stream sites in Indiana, 2000-10.

1-2. Map and diagrams showing significant and non-significant trends in organic nitrogen at 57 stream sites in Indiana, 2000-10

1-3. Map and diagrams showing significant and non-significant trends in phosphorus at 57 stream sites in Indiana, 2000-10

1-4. Map and diagrams showing significant and non-significant trends in suspended solids at 57 stream sites in Indiana, 2000-10

1-5. Map and diagrams showing significant and non-significant trends in copper at 57 stream sites in Indiana, 2000-10

1-6. Map and diagrams showing significant and non-significant trends in iron at 57 stream sites in Indiana, 2000-10.

1-7. Map and diagrams showing significant and non-significant trends in lead at 57 stream sites in Indiana, 2000-10.

1-8. Map and diagrams showing significant and non-significant trends in zinc at 57 stream sites in Indiana, 2000-10

1-9. Map and diagrams showing significant and non-significant trends in chloride at 57 stream sites in Indiana, 2000-10.

1-10. Map and diagrams showing significant and non-significant trends in sulfate at 57 stream sites in Indiana, 2000-10

1-11. Map and diagrams showing significant and non-significant trends in hardness at 57 stream sites in Indiana, 2000-10.

1-12. Map and diagrams showing significant and non-significant trends in dissolved solids at 57 stream sites in Indiana, 2000-10 


\section{Tables}

1. Indiana Fixed Station Monitoring Program stream sites and

U.S. Geological Survey streamgages used in this study..............................................

2. Characteristics of Indiana Fixed Station Monitoring Program

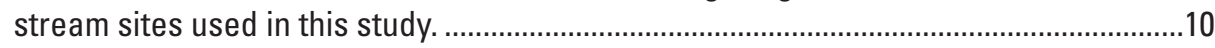

3. Summary statistics for constituent concentrations in Indiana streams, 2000-10 ….......14

4. Summary statistics for constituent concentrations in Indiana streams, 2000-10, by drainage basin

\section{Conversion Factors and Datum}

Inch/Pound to SI

\begin{tabular}{lcl}
\hline \multicolumn{1}{c}{ Multiply } & By & \multicolumn{1}{c}{ To obtain } \\
\hline & Length & \\
\hline inch (in.) & 2.54 & centimeter $(\mathrm{cm})$ \\
inch (in.) & 25.4 & millimeter $(\mathrm{mm})$ \\
mile (mi) & 1.609 & kilometer $(\mathrm{km})$ \\
\hline & Area & \\
\hline acre & 4,047 & square meter $\left(\mathrm{m}^{2}\right)$ \\
acre & 0.4047 & hectare $(\mathrm{ha})$ \\
acre & 0.4047 & square hectometer $\left(\mathrm{hm}^{2}\right)$ \\
acre & 0.004047 & square kilometer $\left(\mathrm{km}^{2}\right)$ \\
square mile $\left(\mathrm{mi}^{2}\right)$ & 2.590 & square kilometer $\left(\mathrm{km}^{2}\right)$ \\
\hline
\end{tabular}

Horizontal coordinate information is referenced to North American Datum of 1983 (NAVD 83).

Temperature in degrees Fahrenheit $\left({ }^{\circ} \mathrm{F}\right)$ may be converted to degrees Celsius $\left({ }^{\circ} \mathrm{C}\right)$ as follows: ${ }^{\circ} \mathrm{C}=\left({ }^{\circ} \mathrm{F}-32\right) / 1.8$

Concentrations of chemical constituents in water are given either in milligrams per liter (mg/L) or micrograms per liter $(\mu \mathrm{g} / \mathrm{L})$. 


\section{Abbreviations}

$\begin{array}{ll}\text { AIMS } & \text { Assessment Information Management System } \\ \text { CBNGP } & \text { Cornbelt and Northern Great Plains } \\ \text { FSMP } & \text { Fixed Station Monitoring Program } \\ \text { GIS } & \text { Geographic Information System } \\ \text { IDEM } & \text { Indiana Department of Environmental Management } \\ \text { MGDR } & \text { Mostly Glaciated Dairy Region } \\ \text { NHD } & \text { National Hydrography Dataset } \\ \text { NWIS } & \text { National Water Information System } \\ \text { PARMA } & \text { Periodic Autoregressive Moving Average } \\ \text { STFPH } & \text { Southeast Temperate Forested Plains and Hills } \\ \text { USGS } & \text { U.S. Geological Survey }\end{array}$




\title{
Water Quality in Indiana: Trends in Concentrations of Selected Nutrients, Metals, and lons in Streams, 2000-10
}

\author{
By Martin R. Risch, Aubrey R. Bunch, Aldo V. Vecchia, Jeffrey D. Martin, and Nancy T. Baker
}

\section{Abstract}

Water quality in Indiana streams generally improved during the 2000-10 study period, based on trends in selected nutrients, metals, and ions. This study combined water-quality data from the Indiana Fixed Station Monitoring Program (FSMP) with streamflow data from nearby U.S. Geological Survey streamgages. A parametric time-series model, QWTREND, was used to develop streamflow-adjusted constituent concentrations, to adjust for seasonal variance and serial correlation, and to identify trends independent of streamflowrelated variability. This study examined 7,345 water samples from 57 FSMP sites for 11 years. Concentration trends were analyzed for 12 constituents - the nutrients nitrate, organic nitrogen, and phosphorus; suspended solids; the metals copper, iron, lead, and zinc; the ions chloride, and sulfate together with hardness as a measure of the calcium carbonate ion; and dissolved solids.

Nutrient concentrations in this study generally were too high relative to standards and criteria. The national recommended criteria for the three ecoregions in Indiana were exceeded by more than one-half of the nitrate and most of the phosphorus concentrations. Copper, lead, zinc, chloride, sulfate, and dissolved solids concentrations were in acceptable ranges relative to standards and criteria in more than 97 percent of samples. The two Lake Michigan Basin sites had the highest concentrations and were in a unique statistical group for 10 of the 12 constituents, with concentrations many times higher than the statewide median and higher than the medians of most other basins. The two Ohio River Basin sites had the lowest concentrations and were in a unique statistical group for 6 of the 12 constituents.

Statistically significant trends were identified that included 167 downward trends and 83 upward trends. The Kankakee River Basin had the most significant upward trends while the most significant downward trends were in the Whitewater River Basin, the Lake Michigan Basin, and the Patoka River Basin. For most constituents, a majority of sites had significant downward trends. Two streams in the Lake Michigan Basin have shown substantial decreases in most constituents. The West Fork White River near Indianapolis, Indiana, showed increases in nitrate and phosphorus and the
Kankakee River Basin showed increases in copper, zinc, chloride, sulfate, and hardness. Upward trends in nutrients were identified at a few sites, but most nutrient trends were downward. Upward trends in metals corresponded with relatively small concentration increases while downward trends involved considerably larger concentration changes. Downward trends in chloride, sulfate, and suspended solids were observed statewide, but upward trends in hardness were observed in the northern half of Indiana.

\section{Introduction}

This study combined water-quality and streamflow data from two monitoring programs in Indiana to determine temporal trends in concentrations of selected constituents. A longterm, State-operated network of sites with laboratory analysis of monthly water samples provided an archive of information about stream chemistry. A long-term, federally managed network of streamgages provided daily mean streamflow values. For sites at or close to streamgages, data were combined to understand changes in stream-water quality that were independent of changes in streamflow.

In 2012, the Indiana Department of Environmental Management (IDEM) evaluated their Fixed Station Monitoring Program (FSMP) and determined that an assessment of trends in constituent concentrations was needed. In 2013, the U.S. Geological Survey (USGS), in cooperation with the IDEM, completed an initial study of the FSMP data, which is described in this report. An important element of this study was that water-quality concentration data were combined with streamflow data from associated USGS streamgages and analyzed with sophisticated statistical techniques to identify and quantify trends as described in the Methods section of this report.

Knowledge about long-term temporal changes in water quality is important for water-resource and land-use managers, public officials, planners, scientists, and citizens. This knowledge includes the number and location of stream sites with long-term increases or decreases in concentrations of selected constituents, along with the significance and magnitude of these changes. Trends in constituent concentrations from a 
stream or streams in a major drainage basin can be indicative of the effectiveness of regulatory and voluntary actions intended to protect and improve water quality. Trends may reveal regional rather than local conditions and may involve point-source and nonpoint-source causes.

This study for Indiana is comparable with other modern studies that have reviewed trends in water-quality constituents in networks spanning major watersheds or geographic regions. In the following examples, which are discussed later in this report, streamflow and water-chemistry information were used for the trends analysis and the analysis was for decade-long or multi-decade time frames. Murphy and others (2013) provide an update on nitrate trends in the Mississippi River and its tributaries for 1980-2010. Lorenz and others (2008) examined trends in nutrients and suspended sediment in watersheds of the north-central U.S. for 1975-2004. Sprague and others (2009) investigated trends in nutrients in major rivers of the U.S. for 1993-2003. Galloway and others (2012) studied trends in nutrients, metals, and ions for North Dakota streams.

\section{Fixed Station Monitoring Program in Indiana}

Since 1957, the IDEM has routinely monitored water quality in streams in Indiana as part of the FSMP. The main use of the FSMP has been to provide data for preparing and reviewing permits for wastewater discharges and evaluating associated stream-water quality. As of 2012, there were 163 sites in the FSMP at which monthly grab samples of water were collected for laboratory analysis of water chemistry (primarily nutrients, metals, and ions) and indicator bacteria, and field determinations of water-quality properties (water temperature, dissolved oxygen, and $\mathrm{pH}$ ). Detailed documentation of laboratory analytical and quality-assurance methods for the FSMP are not provided in this report, but the quality and consistency of the data were assumed to be suitable for trends analysis. The water-quality data are archived in the Indiana Assessment Information Management System (AIMS) database (Indiana Department of Environmental Management, 2013). The FSMP data provide an extensive archive of time-series water-quality information for the major streams and drainage basins in Indiana, including multiple locations from upstream to downstream in these drainage basins. Other sources of information about the FSMP are the Indiana Department of Environmental Management (2006) and the Indiana Water Monitoring Council (2013).

\section{Streamflow Monitoring Program in Indiana}

Streamflow is the amount of water in a stream, moving past a monitoring location (called a streamgage), per unit time. Streamflow, the term used in this report, involves the measurement and calculation of discharge, which is the product of stream velocity and stream cross-section area. The USGS has maintained a statewide network of streamgages in Indiana since the 1930s (Jian and others, 2012). In 2012, there were
202 USGS streamgages in Indiana. At these streamgages, a continuous record of stream stage (water height above a datum) is measured and combined with periodic measurements and calculations of discharge during a range of conditions. The mathematical relation of stream stage and discharge at each streamgage is determined, and a continuous record of discharge is calculated. The streamflow data from the USGS streamgages are archived in the National Water Information System (NWIS; U.S. Geological Survey, 2013a) database. The USGS National Streamflow Information Program is described at U.S. Geological Survey (2013b).

Streamflow is important for understanding trends in water quality because as the amount of water moving in a stream increases and decreases, constituent concentrations measured in time-series water samples can change. Statistical analysis to distinguish the changes in constituent concentrations that are independent of changes in streamflow can provide useful indicators to evaluate the effectiveness of pollution control and management programs.

\section{Purpose and Scope}

This report presents summary statistics and trends for concentrations of selected constituents in monthly water samples at 57 Indiana FSMP stream sites at or nearby a USGS streamgage. Although Indiana streamflow data were used, trends in streamflow alone were beyond the scope of this study. The 12 selected constituents are the nutrients nitrate, organic nitrogen, and phosphorus; suspended solids; the metals copper, iron, lead, and zinc; the ions chloride, and sulfate together with hardness as a measure of the calcium carbonate ion; and dissolved solids. The time period for the summary statistics and trends is 11 years (January 1, 2000-December $31,2010)$. This report does not attempt to explain why trends in concentrations of specific constituents have occurred, or why specific monitoring sites exhibit trends.

\section{Study Area}

Indiana is 35,887 square miles $\left(\mathrm{mi}^{2}\right)$ in size, which is 38th in geographic area in the Nation. The State population census in 2010 was 6.48 million, 15th in the Nation; population density was approximately 181 individuals per square mile. Indiana has approximately 63,130 miles (mi) of rivers and streams (Indiana Department of Environmental Management, 2014); $277 \mathrm{mi}^{2}$ of reservoirs, lakes, and ponds (U.S. Geological Survey, 2014a); ${ }^{1} 1,270 \mathrm{mi}^{2}$ of wetlands (Indiana

\footnotetext{
${ }^{1}$ The National Hydrography Dataset (NHD) of the National Map (U.S. Geological Survey, 2014a), described by Simley and Carswell (2009) was cited by the Indiana Department of Environmental Management (2014) as the source of information for the number of stream miles in Indiana. For this report, the NHD was accessed for Indiana, and the features identified as reservoirs, lakes, and ponds greater than 1 acre at 1:24,000 scale were identified and summed by use of a geographic information system (GIS) and spreadsheet software to determine the area.
} 


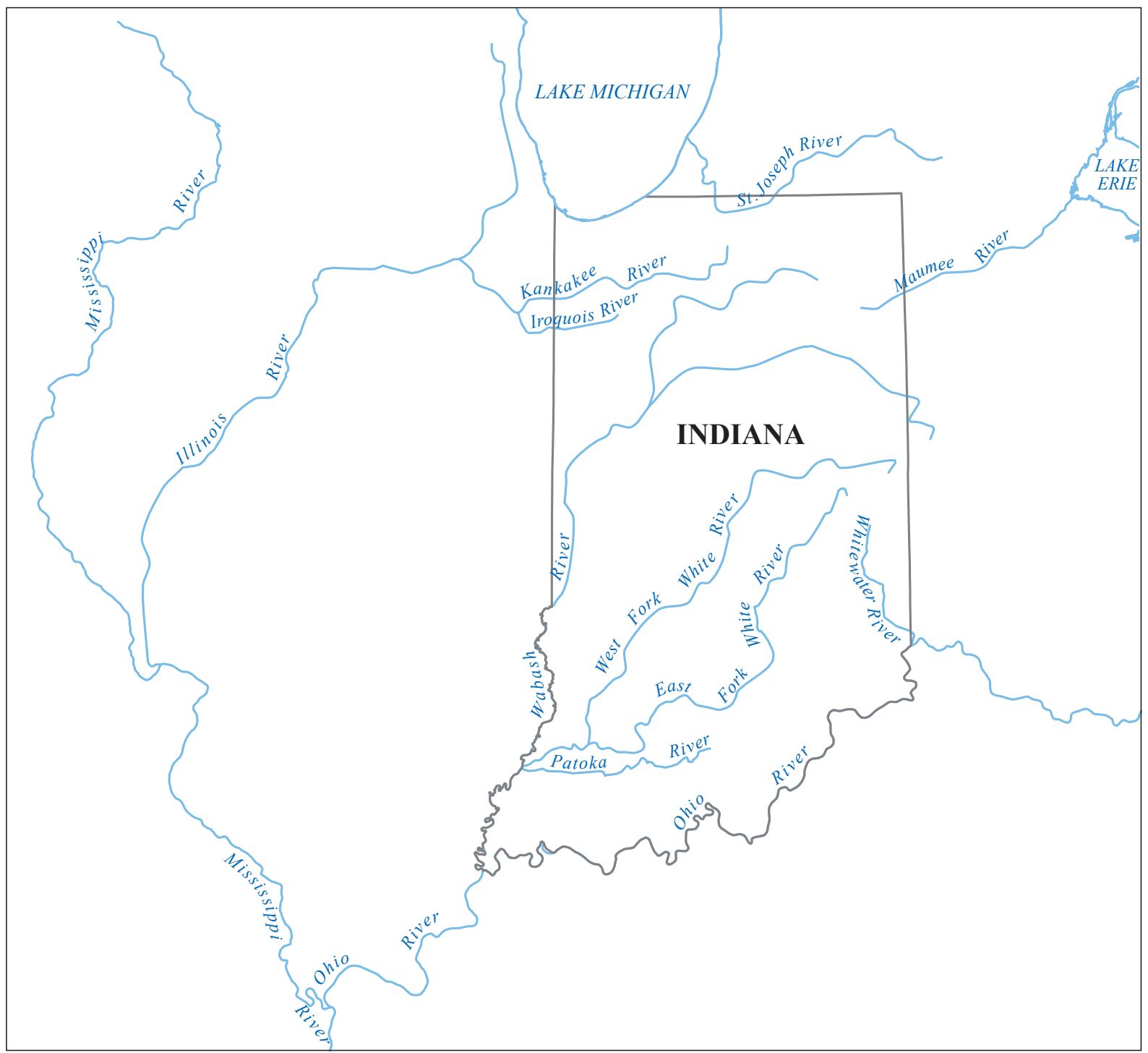

Figure 1. Major rivers in Indiana.

Department of Environmental Management, 2014); and $59 \mathrm{mi}$ of Lake Michigan shoreline (Indiana Department of Environmental Management, 2014).

The climate of Indiana is continental, influenced mainly by eastward-moving cold polar air masses and warm gulf air masses. The low-pressure centers formed by the interaction of these air masses are the major sources of precipitation in Indiana. Spring and early summer are normally the wettest periods of the year, as storm systems tap moisture from the Gulf of Mexico and travel across Indiana. Early fall is generally the driest period. Seasonal precipitation patterns vary statewide, particularly in the summer (when isolated thunderstorms are common) and winter (when lake-effect snows fall in northern Indiana). Normal January minimums range from 15 to 21 degrees Fahrenheit $\left({ }^{\circ} \mathrm{F}\right)$ north to south. July is the warmest month with daily maximums averaging 80 to $83^{\circ} \mathrm{F}$ and minimums of 63 to $65^{\circ} \mathrm{F}$ north to south (Indiana State Climate Office, 2013).
The statewide average annual precipitation ranges from 37 inches (in.) for northern Indiana to nearly 47 in. for southern Indiana. Snowfall (as liquid) accounts for 2 to 7 in. of the average annual precipitation, with the greatest amounts of snowfall in northern Indiana (Indiana State Climate Office, 2013). According to Clark and Larrison (1980), approximately 68 percent of the mean annual precipitation in Indiana returns to the atmosphere through evapotranspiration, 24 percent enters streams and lakes through surface runoff, and 8 percent recharges groundwater. Generally, runoff is greatest in areas with steep slopes and relatively impermeable soils, which are characteristic of much of the southern third of Indiana.

In this report, drainage basins are used to organize data for summarizing concentration statistics and reporting trendanalysis results. A drainage basin, from a water-resources standpoint, is the area that gathers water from precipitation and delivers it to a series of streams that join to form a major river. Major rivers in Indiana (fig. 1) flow either to the Great 
Lakes or to the Mississippi River (Clark and Larrison, 1980). Approximately 10 percent of the land area in Indiana is drained by the St. Joseph River that flows to Lake Michigan and the Maumee River that flows to Lake Erie. Approximately 82 percent of the State land area is drained by rivers that flow to the Ohio River and then to the Mississippi River-the Wabash River, the West Fork White River, the East Fork White River, the Whitewater River, the Patoka River, and tributaries of the Ohio River. Approximately 8 percent of the State land area is drained by rivers that flow to the Illinois River and then to the Mississippi River- the Kankakee River and the Iroquois River.

\section{Methods}

The methods for data compilation, site selection, and constituent selection are described in the following section. Summary information about the study sites is provided. Techniques are explained for the calculation of summary statistics for constituent concentrations statewide and in individual drainage basins, and for determination of significant differences in constituent concentrations among the drainage basins in Indiana. In the design of this study, statistical techniques were used that could identify trends in constituent concentrations that were independent of trends in streamflow, as described in this section.

\section{Data Compilation}

Data were compiled for the study with the purpose of selecting sites for trends analysis. Water-quality data for Indiana were obtained from the AIMS for 2000-10. A consistent name and 5-digit NWIS code was assigned to each constituent, along with a consistent unit for concentrations and reporting limits. (A reporting limit is the concentration below which a constituent is considered to not be detected, although a reporting limit may not be equivalent to an analytical detection limit. A value less than the reporting limit is called a censored value.) It was determined that 57 FSMP sites had "complete" annual records, meaning that they had at least 9 of 12 monthly water-quality samples analyzed for a minimum of 16 constituents every year for the period 2000-10. Constituent selection is described in the next section.

Streamflow data for Indiana were obtained from the NWIS database for 2000-10. A GIS (ESRI, 2007) was used to identify 50 USGS streamgages that were collocated or on the same stream reach as the 57 FSMP sites. (Note that more than one FSMP site could be associated with a single streamgage.) A criterion for considering the streamgage and FSMP site to be on the same reach was that a tributary of the next lower stream order did not confluence with the stream of the streamgage between the FSMP site and the streamgage. Similar criteria are in use for retrospective data compilation in the National WaterQuality Assessment Program (U.S. Geological Survey, 2014b).
The program waterData (Ryberg and Vecchia, 2012) was used to screen and standardize zero and missing streamflow values and to mathematically assign probable streamflow values for missing values. The final dataset for this study consisted of 4,015 daily mean streamflow values from the NWIS database for 50 USGS streamgages in Indiana, 2000-10.

\section{Study Sites}

In 2012, 57 of the 163 FSMP sites in Indiana met the site selection criteria for the concentrations trends analysis in this report (fig. 2). Characteristics and locations of the 57 FSMP sites and the 50 associated streamgages in this report are shown in table 1 and figure 3. Among the 57 FSMP sites, the streamgage was collocated at 25 sites, upstream at 25 sites, and downstream at 7 sites (fig. 3). The 57 FSMP sites are located in 10 of the 12 major drainage basins in Indiana (known as hydrologic subregion accounting units in Seaber and others, 1987); the exceptions are the Maumee and St. Joseph River Basins (fig. 3). The number of study sites in the 10 drainage basins is not uniform and ranges from 1 to 4 sites in 7 basins and up to 16 or 17 sites in 2 basins (table 2). The size of the watersheds upstream from the sites were computed with the GIS (fig. $4 A$ ) and ranged from $10 \mathrm{mi}^{2}$ (site 7, table 2) to $13,765 \mathrm{mi}^{2}$ (site 18, table 2); three-fourths of the sites had watershed sizes of $2,031 \mathrm{mi}^{2}$ or less (fig. $4 B$ ).

Streamflow conditions on days of sampling were determined to be representative of overall streamflow conditions during the study period. Distributions of daily mean streamflow, 2000-10, were not significantly different from distributions of daily streamflow at the time of the monthly waterquality samples (Wilcoxon rank-sum test, $\alpha=0.05$ ).

\section{Constituent Selection}

The water-quality data for the 16 constituents at the 57 FSMP sites (2000-10) were examined, and 4 constituents were excluded from this report. The water-quality properties (water temperature and dissolved oxygen) have daily fluctuations, and $\mathrm{pH}$ has a non-linear scale of measurement (characteristics incompatible with the statistical trends-analysis technique used in this study). Ammonia-nitrogen had 87.9 percent censored values, and trend analysis was not meaningful.

For presentation and discussion of results in this report, the 12 constituents selected for the study were divided into 3 groups of 4 constituents each and given simple names. Reported concentrations were total or total recoverable forms of the constituents (with the exception of dissolved solids, by definition). Additional information about the constituents is presented in the Water Quality in Indiana Streams section of this report.

The four constituents in the nutrients and suspended solids group are nitrate plus nitrite as nitrogen (named nitrate in this report); total Kjeldahl nitrogen, known as TKN, the sum of organic nitrogen, ammonia, and ammonium (named organic 


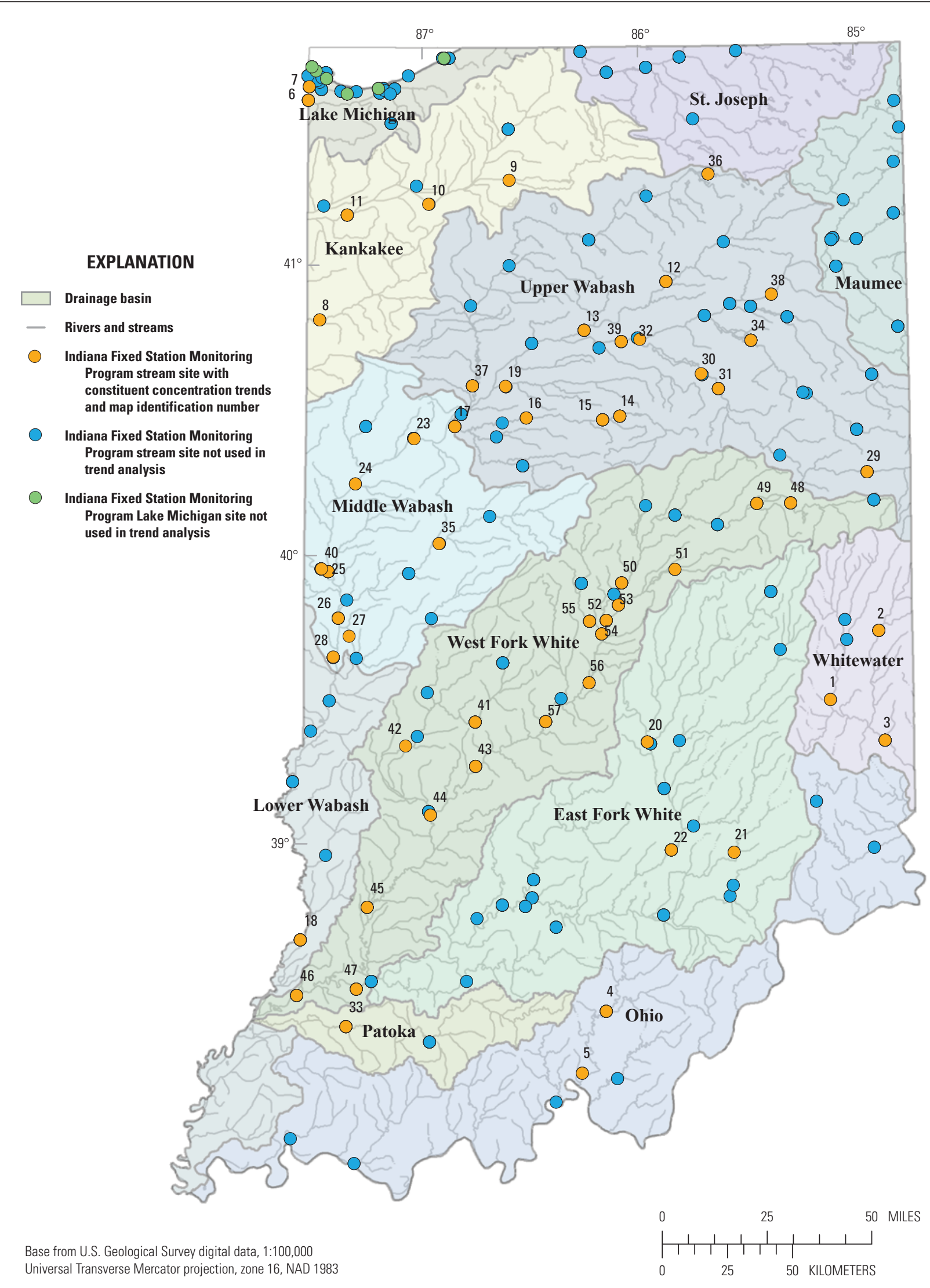

Figure 2. All Indiana Fixed Station Monitoring Program sites and stream sites selected for use in this study. 
Table 1. Indiana Fixed Station Monitoring Program stream sites and U.S. Geological Survey streamgages used in this study.

[ID, identification; FSMP, Fixed Station Monitoring Program; USGS, U.S. Geological Survey]

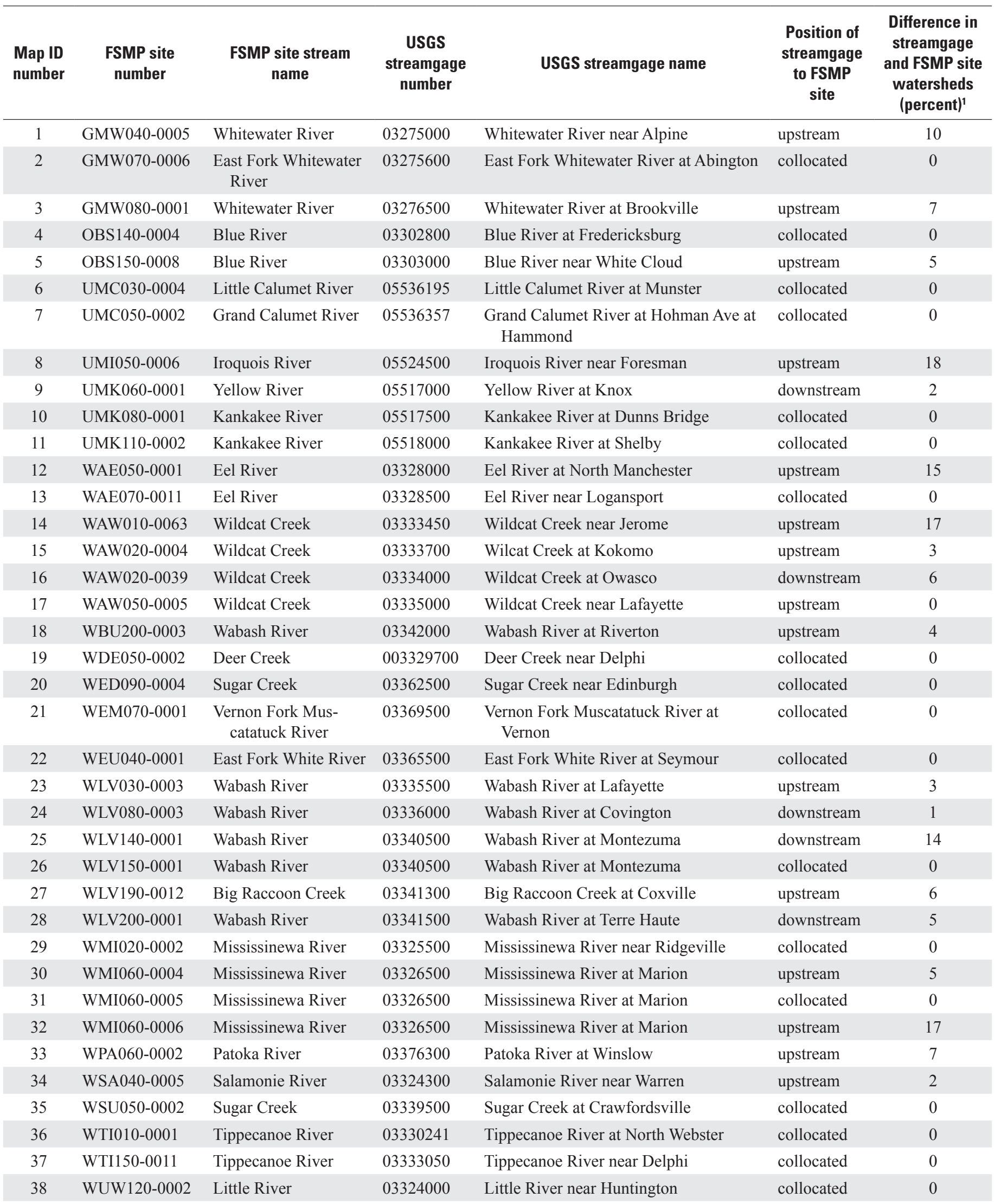

${ }^{1}$ Difference in the watershed area of FSMP site and streamgage as a percentage of the watershed area of the FSMP site. 
Table 1. Indiana Fixed Station Monitoring Program stream sites and U.S. Geological Survey streamgages used in this study.-Continued [ID, identification; FSMP, Fixed Station Monitoring Program; USGS, U.S. Geological Survey]

\begin{tabular}{|c|c|c|c|c|c|c|}
\hline $\begin{array}{l}\text { Map ID } \\
\text { number }\end{array}$ & $\begin{array}{l}\text { FSMP site } \\
\text { number }\end{array}$ & $\begin{array}{l}\text { FSMP site stream } \\
\text { name }\end{array}$ & $\begin{array}{c}\text { USGS } \\
\text { streamgage } \\
\text { number }\end{array}$ & USGS streamgage name & $\begin{array}{l}\text { Position of } \\
\text { streamgage } \\
\text { to FSMP } \\
\text { site }\end{array}$ & $\begin{array}{l}\text { Difference in } \\
\text { streamgage } \\
\text { and FSMP site } \\
\text { watersheds } \\
\text { (percent) }^{1}\end{array}$ \\
\hline 39 & WUW160-0006 & Wabash River & 03327500 & Wabash River at Peru & collocated & 0 \\
\hline 40 & WVE100-0001 & Vermillion River & 03339000 & Vermilion River near Danville IL & upstream & 10 \\
\hline 41 & WWE060-0002 & Mill Creek & 03358000 & Mill Creek near Cataract & collocated & 0 \\
\hline 42 & WWE080-0001 & Eel River & 03360000 & Eel River at Bowling Green & upstream & 4 \\
\hline 43 & WWL020-0003 & $\begin{array}{l}\text { West Fork White } \\
\text { River }\end{array}$ & 03354000 & White River near Centerton & upstream & 18 \\
\hline 44 & WWL030-0003 & $\begin{array}{l}\text { West Fork White } \\
\text { River }\end{array}$ & 03360500 & White River at Newberry & downstream & 7 \\
\hline 45 & WWL070-0003 & $\begin{array}{l}\text { West Fork White } \\
\text { River }\end{array}$ & 03360500 & White River at Newberry & upstream & 6 \\
\hline 46 & WWL100-0001 & White River & 03374000 & White River at Petersburg & upstream & 2 \\
\hline 47 & WWL100-0005 & White River & 03374000 & White River at Petersburg & collocated & 0 \\
\hline 48 & WWU010-0001 & $\begin{array}{l}\text { West Fork White } \\
\text { River }\end{array}$ & 03347000 & White River at Muncie & downstream & 10 \\
\hline 49 & WWU020-0005 & $\begin{array}{l}\text { West Fork White } \\
\text { River }\end{array}$ & 03347000 & White River at Muncie & collocated & 0 \\
\hline 50 & WWU090-0002 & $\begin{array}{l}\text { West Fork White } \\
\text { River }\end{array}$ & 03351000 & White River near Nora & collocated & 0 \\
\hline 51 & WWU100-0001 & Fall Creek & 03351500 & Fall Creek near Fortville & collocated & 0 \\
\hline 52 & WWU110-0001 & Fall Creek & 03352500 & Fall Creek at Millersville & upstream & 6 \\
\hline 53 & WWU110-0002 & Fall Creek & 03352500 & Fall Creek at Millersville & upstream & 5 \\
\hline 54 & WWU120-0001 & Eagle Creek & 03353500 & Eagle Creek at Indianapolis & upstream & 15 \\
\hline 55 & WWU120-0002 & Eagle Creek & 03353500 & Eagle Creek at Indianapolis & collocated & 0 \\
\hline 56 & WWU140-0003 & $\begin{array}{l}\text { West Fork White } \\
\text { River }\end{array}$ & 03353611 & $\begin{array}{l}\text { White River at Stout Generating } \\
\text { Station }\end{array}$ & upstream & 7 \\
\hline 57 & WWU160-0004 & $\begin{array}{l}\text { West Fork White } \\
\text { River }\end{array}$ & 03354000 & White River near Centerton & upstream & 2 \\
\hline
\end{tabular}

${ }^{1}$ Difference in the watershed area of FSMP site and streamgage as a percentage of the watershed area of the FSMP site. 


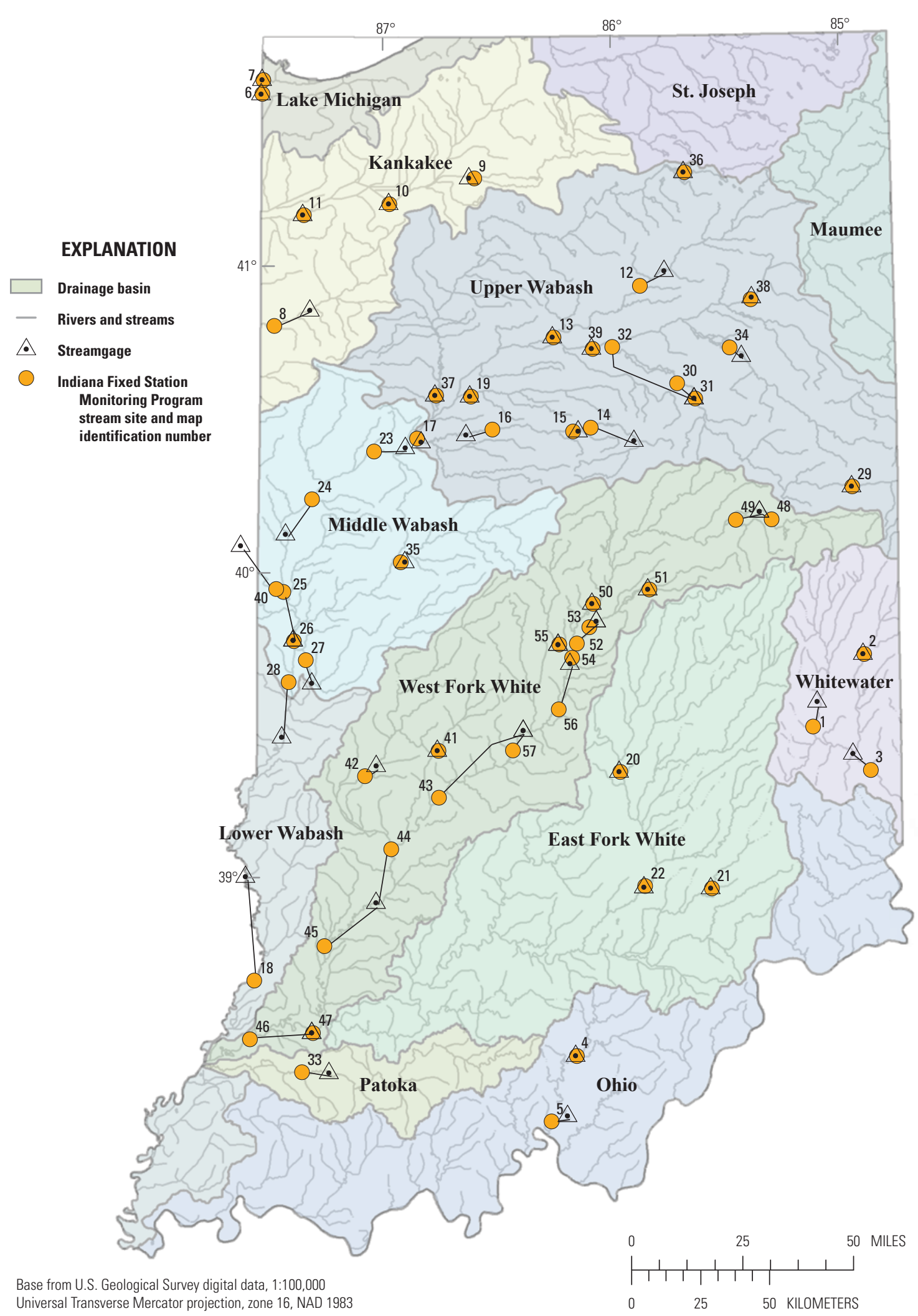

Figure 3. Selected Indiana Fixed Station Monitoring Program stream sites and associated streamgages used in this study. 


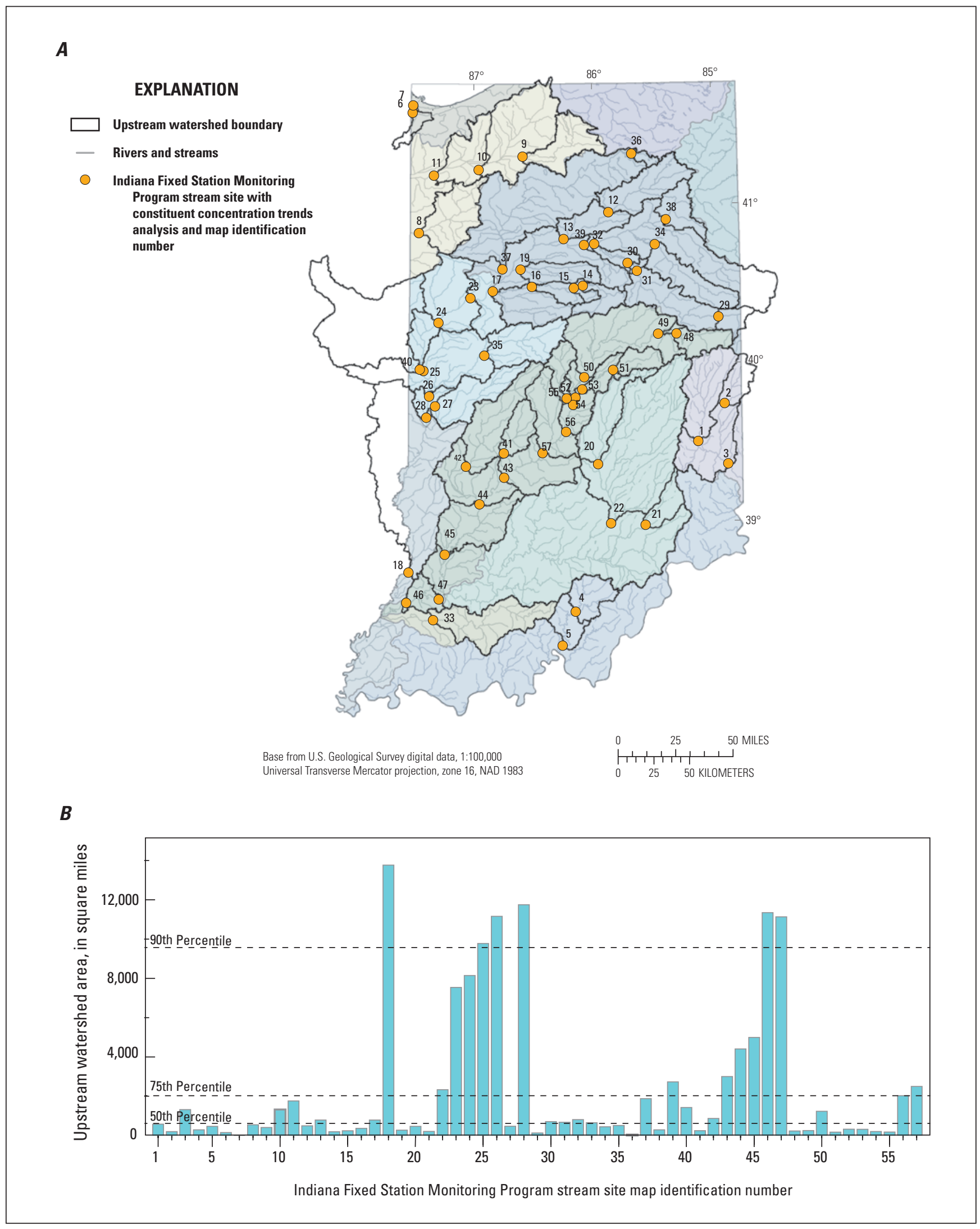

Figure 4. Indiana Fixed Station Monitoring Program stream sites used in this study with diagram of upstream watershed size. $A$, Map. B, Diagram. 
[ID, identification; FSMP, Fixed Station Monitoring Program; mi², square mile; Rd, road; R., River; SR, State Road; US, United States (Highway); Ave, Avenue; CR County Road; W, west; E, east; N, north; St, Street; S, south; Dr, Drive]

\begin{tabular}{|c|c|c|c|c|c|c|c|}
\hline $\begin{array}{l}\text { Map ID } \\
\text { number }\end{array}$ & FSMP historic site ID and site description & $\begin{array}{l}\text { Indiana } \\
\text { county }\end{array}$ & $\begin{array}{l}\text { Major drainage } \\
\text { basin }\end{array}$ & Latitude & Longitude & $\begin{array}{l}\text { Hydrologic } \\
\text { unit code }\end{array}$ & $\begin{array}{c}\text { Upstream } \\
\text { watershed } \\
\left(\mathrm{mi}^{2}\right)\end{array}$ \\
\hline 1 & WHW-47, Whitewater River, Laurel Rd, Laurel & Franklin & Whitewater R. & 39.49806 & 85.18250 & 50800030408 & 579 \\
\hline 2 & $\begin{array}{l}\text { WHE-27, East Fork Whitewater River, Potter Shop Rd, } \\
\text { Abbington }\end{array}$ & Wayne & Whitewater R. & 39.73250 & 84.95972 & 50800030710 & 200 \\
\hline 3 & WHW-22, Whitewater River, old SR 1 & Franklin & Whitewater R. & 39.35333 & 84.94278 & 50800030805 & 1,319 \\
\hline 4 & BLW-57, Blue River, US 150, Fredericksburg & Washington & Ohio R. & 38.43389 & 86.19167 & 51401040805 & 294 \\
\hline 5 & BLW-10, Blue River, off of SR 62, Near Wyandotte Cave & Crawford & Ohio R. & 38.22056 & 86.29833 & 51401040905 & 468 \\
\hline 6 & LCR-13, Little Calumet River, Hohman Ave, Hammond & Lake & Lake Michigan & 41.57778 & 87.52222 & 71200030305 & 153 \\
\hline 7 & GCR-34, Grand Calumet River, Hohman Ave, Hammond & Lake & Lake Michigan & 41.62444 & 87.51778 & 71200030407 & 10 \\
\hline 8 & I-63, Iroquois River, CR $400 \mathrm{~W}$, north of Kentland & Newton & Kankakee R. & 40.82014 & 87.46403 & 71200020503 & 548 \\
\hline 9 & YR-12, Yellow River, CR 500 E, east of Knox & Starke & Kankakee R. & 41.30229 & 86.60154 & 71200010506 & 413 \\
\hline 10 & KR-91, Kankakee River, CR 500 E, Dunns Bridge & Porter & Kankakee R. & 41.22001 & 86.96908 & 71200010807 & 1,327 \\
\hline 11 & KR-68, Kankakee River, SR 55, Shelby & Newton & Kankakee R. & 41.18270 & 87.34058 & 71200011103 & 1,761 \\
\hline 12 & ELL-41, Eel River, SR 15, northeast of Roann & Wabash & Upper Wabash R. & 40.94792 & 85.89076 & 51201040509 & 496 \\
\hline 13 & ELL-7, Eel River, CR 150 N, northeast of Logansport & Cass & Upper Wabash R. & 40.78233 & 86.26450 & 51201040705 & 789 \\
\hline 14 & WC-66, Wildcat Creek, US 31, Kokomo & Howard & Upper Wabash R. & 40.48611 & 86.10750 & 51201070109 & 195 \\
\hline 15 & WC-60, Wildcat Creek, CR 300 W, near Kokomo & Howard & Upper Wabash R. & 40.47361 & 86.18417 & 51201070403 & 244 \\
\hline 16 & WC-32, Wildcat Creek, SR 75, near Cutler & Carroll & Upper Wabash R. & 40.48179 & 86.53010 & 51201070408 & 366 \\
\hline 17 & WC-3, Wildcat Creek, SR 25, near Lafayette & Tippecanoe & Upper Wabash R. & 40.45378 & 86.85139 & 51201070409 & 789 \\
\hline 18 & WB-130, Wabash River, Vigo St, Vincennes & Knox & Lower Wabash R. & 38.68125 & 87.53472 & 51201111903 & 13,765 \\
\hline 19 & DC-5, Deer Creek, CR 300 N, Northeast of Delphi & Carroll & Upper Wabash R. & 40.59050 & 86.62140 & 51201050508 & 276 \\
\hline 20 & SGR-1, Sugar Creek, CR 800 S, Edinburgh & Johnson & East Fork White R. & 39.36083 & 85.99806 & 51202040705 & 468 \\
\hline 21 & VF-38, Vernon Fork Muscatatuck River, CR 60 S, Vernon & Jennings & East Fork White R. & 38.97639 & 85.62000 & 51202070701 & 209 \\
\hline 22 & EW-168. East Fork White River, CR 725 N, Seymour & Jackson & East Fork White R. & 38.98722 & 85.89889 & 51202060502 & 2,336 \\
\hline 23 & WB-303, Wabash River, CR 300 W, near Lafayette & Tippecanoe & Middle Wabash R. & 40.41182 & 87.03624 & 51201080503 & 7,537 \\
\hline 24 & WB-284, Wabash River, CR 2000 W, Williamsport & Warren & Middle Wabash R. & 40.25509 & 87.29967 & 51201080604 & 8,142 \\
\hline 25 & WB-256, Wabash River, SR 234, Cayuga & Vermillion & Middle Wabash R. & 39.95179 & 87.41964 & 51201081602 & 9,773 \\
\hline 26 & WB-240, Wabash River, US 36, Montezuma & Vermillion & Middle Wabash R. & 39.79243 & 87.37415 & 51201081605 & 11,158 \\
\hline 27 & RC-5, Big Racoon Creek, Mecca & Parke & Middle Wabash R. & 39.72938 & 87.32497 & 51201081504 & 475 \\
\hline 28 & WB-230, Wabash River, near SR 163, Clinton & Vermillion & Middle Wabash R. & 39.65767 & 87.39582 & 51201081607 & 11,747 \\
\hline 29 & MS-99, Mississinewa River, CR 100 W, near Ridgeville & Randolph & Upper Wabash R. & 40.28000 & 84.99528 & 51201030203 & 133 \\
\hline 30 & MS-28, Mississinewa River, off of CR 380 W, Jalapa & Grant & Upper Wabash R. & 40.62806 & 85.73583 & 51201030601 & 710 \\
\hline
\end{tabular}


Table 2. Characteristics of Indiana Fixed Station Monitoring Program stream sites used in this study.-Continued

[ID, identification; FSMP, Fixed Station Monitoring Program; mi², square mile; Rd, road; R., River; SR, State Road; US, United States (Highway); Ave, Avenue; CR County Road; W, west; E, east; N, north; St, Street; S, south; Dr, Drive]

\begin{tabular}{|c|c|c|c|c|c|c|c|}
\hline $\begin{array}{l}\text { Map ID } \\
\text { number }\end{array}$ & FSMP historic site ID and site description & $\begin{array}{l}\text { Indiana } \\
\text { county }\end{array}$ & $\begin{array}{l}\text { Major drainage } \\
\text { basin }\end{array}$ & Latitude & Longitude & $\begin{array}{l}\text { Hydrologic } \\
\text { unit code }\end{array}$ & $\begin{array}{c}\text { Upstream } \\
\text { watershed } \\
\left(\mathrm{mi}^{2}\right)\end{array}$ \\
\hline 31 & MS-36, Mississinewa River, near Highland Ave, Marion & Grant & Upper Wabash R. & 40.57611 & 85.65972 & 51201030601 & 677 \\
\hline 32 & MS-1, Mississinewa River, SR 124, near Peru & Miami & Upper Wabash R. & 40.74937 & 86.01206 & 51201030606 & 812 \\
\hline 33 & P-35, Patoka River, CR 300 W, near Oakland City & Pike & Patoka R. & 38.38250 & 87.33333 & 51202090605 & 652 \\
\hline 34 & S-25, Salamonie River, SR 124, near Lancaster & Huntington & Upper Wabash R. & 40.74167 & 85.50889 & 51201020405 & 448 \\
\hline 35 & SC-39, Sugar Creek, US 136, Crawfordsville & Montgomery & Upper Wabash R. & 40.05006 & 86.92269 & 51201100604 & 512 \\
\hline 36 & TR-164, Tippecanoe River, SR 13, North Webster & Kosciusko & Upper Wabash R. & 41.31639 & 85.69222 & 51201060105 & 51 \\
\hline 37 & TR-9, Tippecanoe River, SR 18, near Delphi & Carroll & Upper Wabash R. & 40.59382 & 86.77071 & 51201061309 & 1,878 \\
\hline 38 & LR-7, Little River, CR 200 E, near Huntington & Huntington & Upper Wabash R. & 40.89861 & 85.41333 & 51201011103 & 290 \\
\hline 39 & WB-370, Wabash River, Business US 31 & Miami & Upper Wabash R. & 40.74276 & 86.09622 & 51201011602 & 2,730 \\
\hline 40 & V-0.8, Vermillion River, SR 63, Cayuga & Vermillion & Middle Wabash R. & 39.96178 & 87.45085 & 51201090907 & 1,429 \\
\hline 41 & MC-18, Mill Creek, US 231 & Owen & West Fork White R. & 39.43333 & 86.76333 & 51202030512 & 251 \\
\hline 42 & EEL-38, Eel River, CR 200 E, near Bowling Green & Clay & West Fork White R. & 39.35068 & 87.07278 & 51202030706 & 873 \\
\hline 43 & WR-162, West Fork White River, South Main St, Spencer & Owen & West Fork White R. & 39.28028 & 86.76194 & 51202020205 & 3,002 \\
\hline 44 & WR-134, West Fork White River, SR 157, Worthington & Greene & West Fork White R. & 39.11194 & 86.96250 & 51202020404 & 4,407 \\
\hline 45 & WR-81, West Fork White River, SR 358, near Edwardsport & Daviess & West Fork White R. & 38.79500 & 87.24167 & 51202020803 & 4,993 \\
\hline 46 & WR-19, White River, Old US 41, Hazleton & Gibson & West Fork White R. & 38.49000 & 87.55000 & 51202021007 & 11,344 \\
\hline 47 & WR-46, White River, SR 61, Petersburg & Pike & West Fork White R. & 38.51167 & 87.28861 & 51202021001 & 11,129 \\
\hline 48 & WR-319, West Fork White River, Memorial Dr, Muncie & Delaware & West Fork White R. & 40.17833 & 85.34222 & 51202010110 & 231 \\
\hline 49 & WR-309, West Fork White River, Tiger Drive, Yorktown & Delaware & West Fork White R. & 40.17889 & 85.49500 & 51202010305 & 253 \\
\hline 50 & WR-248, West Fork White River, 86th St, Nora & Marion & West Fork White R. & 39.91037 & 86.10503 & 51202011006 & 1,233 \\
\hline 51 & FC-26, Fall Creek, SR 238, Fortville & Hamilton & West Fork White R. & 39.95444 & 85.86694 & 51202010808 & 174 \\
\hline 52 & FC-0.6, Fall Creek, Stadium Dr, Indianapolis & Marion & West Fork White R. & 39.78173 & 86.17679 & 51202010904 & 322 \\
\hline 53 & FC-7, Fall Creek, Keystone Ave, Indianapolis & Marion & West Fork White R. & 39.83434 & 86.12189 & 51202010904 & 319 \\
\hline 54 & EC-1, Eagle Creek, Raymond St, Indianapolis & Marion & West Fork White R. & 39.73528 & 86.19658 & 51202011110 & 209 \\
\hline 55 & EC-7, Eagle Creek, Lynhurst Dr, Indianapolis & Marion & West Fork White R. & 39.77825 & 86.25067 & 51202011110 & 177 \\
\hline 56 & WR-210, West Fork White River, SR 144, near Waverly & Morgan & West Fork White R. & 39.56694 & 86.25583 & 51202011402 & 2,031 \\
\hline 57 & WR-192, West Fork White River, SR 39, Martinsville & Morgan & West Fork White R. & 39.43389 & 86.44944 & 51202011503 & 2,499 \\
\hline
\end{tabular}


nitrogen in this report); total phosphorus (named phosphorus in this report); and total suspended solids ${ }^{2}$ (named suspended solids in this report). The four constituents in the metals group are copper, iron, lead, and zinc. The four constituents in the ions and dissolved solids group are chloride, sulfate, hardness as calcium carbonate (named hardness in this report), and total dissolved solids (named dissolved solids in this report). ${ }^{3}$

An evaluation of the concentration values for the 12 selected constituents was made to identify extreme outliers and to reconcile multiple reporting limits for censored values. Rank-ordered data indicated a total of 3 high values for 3 constituents were more than 20 to 700 times the interquartile range for each constituent, and these 3 extreme outlier values were removed from the data for this study. Multiple reporting limits were observed for censored values of the constituents organic nitrogen, phosphorus, suspended solids, copper, lead, and zinc, so the highest reporting limit was applied to a small number of censored values, to be compatible with the statistical trends-analysis technique used in this study. The final dataset for this study consisted of 86,110 concentration values from the AIMS database for the 12 constituents in 7,345 water samples from 57 FSMP sites for 2000-10.

\section{Statistical Analysis}

The parametric statistical time-series model for detecting trends (called QWTREND), developed by USGS and described in Vecchia $(2000,2003,2005)$ and supplemental documentation (Vecchia, 2004a, 2004b), was used to determine whether there were statistically significant trends in concentrations of the 12 water-quality constituents in this study. The QWTREND model is used for analyzing streamflow-related variability in constituent concentrations so that time-series constituent concentration trends independent of streamflow-related variability can be determined. Most of the variability in constituent concentrations is caused by variability in streamflow. This streamflow-related variability is often complex and cannot be determined by a simple regression model of constituent concentration and streamflow at the time of sample collection. Streamflow conditions for days, months, or even years prior to the water-quality sample can affect concentration. Concentration data with streamflowrelated variability removed, called flow-adjusted concentrations, usually have seasonal variance and serial correlation structure remaining, that can cause problems in statistical

\footnotetext{
${ }^{2}$ It is known that nutrients, particularly phosphorus, are attached to suspended sediment in water (U.S. Geological Survey, 2013c) and that is why suspended solids are grouped with the nutrients. Note that the suspended solids in a sample can be inorganic and organic in origin and may or may not include attached nutrients. Also, other constituents will attach to and can be part of the suspended sediment, including the metals in this study.

${ }^{3}$ Total dissolved solids includes the anions chloride, sulfate, and calcium carbonate, but also nitrate (Hem, 1985) and cations such as aluminum, magnesium, potassium, sodium, and silica.
}

trends analysis. The QWTREND model for daily streamflow and constituent concentration adjusts for seasonal variance and serial correlation.

To detect the water-quality trends for this study, concentration data were partitioned into several components according to the following equation:

$$
\log (\mathrm{C})=\mathrm{MC}+\mathrm{ANNC}+\mathrm{SEASC}+\mathrm{HFVC}+\mathrm{TRENDC}
$$

where

$\log$ denotes the base-10 logarithm;

$\mathrm{C}$ is the concentration, in milligrams or micrograms per liter;

MC is the long-term mean of the log-transformed concentration, as the base-10 logarithm of milligrams or micrograms per liter;

ANNC is the annual concentration variability (dimensionless);

SEASC is the seasonal concentration variability (dimensionless);

HFVC is the high-frequency variability of the concentration (dimensionless); and

TRENDC is the concentration trend (dimensionless).

The annual concentration variability ANNC, seasonal concentration variability SEASC, and high-frequency variability HVFC terms represent natural variability in concentration for different time scales. Annual, seasonal, and high-frequency variability in streamflow contribute to concentration variability, but are uncorrelated at any specific time and depend only on streamflow up to that specific time (Ryberg and Vecchia, 2012).

ANNC is an estimate of the interannual variability in concentration that can be attributed to long-term variability in streamflow. For example, extended dry and wet periods affect the proportions of surface runoff and base flow in streams, which can change the water quality. SEASC is an estimate of the seasonal variability in concentration that can be attributed to seasonal variability in streamflow or to seasonality in other factors other than streamflow. For example, seasonal snowmelt and water temperatures affect water quality, as can seasonal applications of fertilizer or road deicers. HFVC is an estimate of the variability in concentration for time scales of several days or weeks that are shorter than a season. For example, daily changes in weather may cause variability in streamflow and water quality. Unlike annual and seasonal concentration variability, which depend on antecedent streamflow, high-frequency variability includes serial correlation among concentrations, the tendency for high or low values to persist for several days or weeks before returning to normal.

TRENDC is an estimate of the long-term systematic changes in concentration that are unrelated to long-term variability in streamflow. A statistically significant trend might indicate changes in human activities that affect water quality. Trends from different causes can occur at different times 
and in different directions, so the trends in this study are not monotonic (entirely upward or entirely downward). Trends can persist for a short time before ending or reversing direction. For this study, a trend was defined as a statistically significant increase or decrease in median concentration for a period of at least 11 years, 2000-10.

QWTREND includes the bivariate, periodic autoregressive moving average (PARMA) model fitted to the high-frequency variability of streamflow and concentration to account for serial correlation and nonstationarity (Vecchia, 2000). The PARMA model is fitted using Gaussian maximum likelihood estimation. For this study, QWTREND was used to determine trends of increasing concentrations (uptrends) and decreasing concentrations (downtrends) during the 11-year study period. Statistically significant trends were identified when the probability of a Type I error ${ }^{4}$ was less than 5 percent $(\alpha=0.05)$. The magnitude of uptrends and downtrends were measured as a percent change and as a concentration change between the median annual concentration in 2000 and the median annual concentration in 2010.

Significant differences in constituent concentrations among basins were determined with a statistical technique that took into account the censored values for 6 of the 12 constituents. The technique was the generalized Wilcoxon test (Helsel, 2004), which compares two groups at a time using a null hypothesis that the locations (central tendency) of the distributions of the groups differ by zero. For discussion in this report, the median is used to describe the central tendency of a group.

Summary statistics for constituents with censored data were determined by use of the Maximum-Likelihood Estimation technique (Helsel and Hirsch, 2002). Although the concentration data were assumed to have a lognormal distribution, this technique provides unbiased estimates of percentiles, median, and interquartile range for a variety of data distributions for environmental studies, even those which are not lognormal.

\section{Water Quality in Indiana Streams}

This section provides a description of each constituent with a statistical summary of concentrations in Indiana during the study period. The standards and criteria for each constituent are explained and compared with the concentrations in Indiana. Trends in constituent concentrations during the study period are identified and discussed.

\footnotetext{
${ }^{4}$ A Type I error in statistics is identification of a significant trend when no trend was actually present.
}

\section{Constituents, Criteria, and Concentrations}

The following discussion provides background information on the 12 constituents and relies on information from Hem (1985), the Indiana water-quality standards rules for surface water (Indiana Administrative Code, 2013), and the national recommended fresh-water-quality criteria (U.S. Environmental Protection Agency, 2009 and references therein). Concentrations of the constituents at the sites in this study have been summarized statewide (table 3 ). Six constituentsnitrate, iron, chloride, sulfate, hardness, and dissolved solidsdid not have censored values. Censored values were less than 9 percent of samples for each of the other constituents, with the exception of lead (57.9 percent) and zinc (34.6 percent).

\section{Nutrients and Suspended Solids}

Nutrients for plants include nitrogen, phosphorus, and potassium. As described earlier, the constituents nitrate, organic nitrogen, and phosphorus are included in this study, along with suspended solids that may be a substrate for nutrient transport.

Nitrate is the main anion form of nitrogen in water, generally found with lesser amounts of nitrite, ammonia, and organic nitrogen. The nitrogen cycle includes components in the air, water, land, and biota. Nitrogen levels in water can be increased by wastewater discharges and fertilizer runoff. Excessive nitrogen in water can lead to harmful algal blooms, eutrophication, and depleted oxygen. The Indiana rules list a criterion for nitrate plus nitrite nitrogen of 10 milligrams per liter $(\mathrm{mg} / \mathrm{L})$, applied at the point of public-water system intake to protect human health. A chronic aquatic criterion for nitrate plus nitrite nitrogen is not listed in the Indiana rules. Nitrate concentrations in this study exceeded the $10 \mathrm{mg} / \mathrm{L}$ Indiana water-quality standard in 87 samples (1.2 percent); the maximum concentration was $17 \mathrm{mg} / \mathrm{L}$.

Organic nitrogen includes natural materials such as proteins, peptides, nucleic acids, urea, and synthetic organic materials. Organic nitrogen levels can be high in sewage and animal wastes, as can ammonia. A criterion for organic nitrogen is not listed in the Indiana rules.

Phosphorus is an element with small concentrations in water because of the low solubility of its inorganic ions and uptake by biota as a nutrient. Analysis of total phosphorus in water includes dissolved, mostly orthophosphate ions, and particulate forms. Phosphorus is a component of sewage and fertilizer, and levels in water can be increased by wastewater discharges and fertilizer runoff. Excessive phosphorus in water can contribute to harmful algal blooms, eutrophication, and depleted oxygen. A criterion for phosphorus is not listed in the Indiana rules.

The national recommended water-quality criteria for nutrients are listed by aggregate ecoregion (fig. 5), which in Indiana are the Cornbelt and Northern Great Plains (CBNGP) for most of the State, the Mostly Glaciated Dairy Region 
Table 3. Summary statistics for constituent concentrations in Indiana streams, 2000-10.

[n, number of samples; $\mathrm{mg} / \mathrm{L}$, milligrams per liter; POI, criteria applied at point of intake for public water supply; <, less than; not set, criteria not established; $\mu \mathrm{g} / \mathrm{L}$, micrograms per liter]

\begin{tabular}{|c|c|c|c|c|c|c|c|c|c|c|c|c|}
\hline Constituent & $\begin{array}{c}\text { Reporting } \\
\text { limit }\end{array}$ & Mean & Minimum & $\begin{array}{c}\text { 25th } \\
\text { percentile }\end{array}$ & Median & $\begin{array}{c}\text { 75th } \\
\text { percentile }\end{array}$ & Maximum & $\mathbf{n}$ & $\begin{array}{l}\text { Number } \\
\text { censored }\end{array}$ & $\begin{array}{c}\text { Percent } \\
\text { censored }\end{array}$ & $\begin{array}{l}\text { Indiana } \\
\text { criteria }^{1}\end{array}$ & $\begin{array}{l}\text { National } \\
\text { criteria }^{2}\end{array}$ \\
\hline Nitrate & $0.1 \mathrm{mg} / \mathrm{L}$ & 3.1 & 0.1 & 1.6 & 2.6 & 4.1 & 17 & 7,156 & 0 & 0 & $\begin{array}{c}10 \mathrm{mg} / \mathrm{L} \\
(\mathrm{POI})\end{array}$ & ecoregion $^{3}$ \\
\hline Organic nitrogen & $0.1 \mathrm{mg} / \mathrm{L}$ & 0.9 & $<0.1$ & 0.5 & 0.8 & 1.1 & 16 & 7,260 & 79 & 1.1 & not set & ecoregion $^{3}$ \\
\hline Phosphorus & $0.03 \mathrm{mg} / \mathrm{L}$ & 0.19 & $<0.03$ & 0.07 & 0.14 & 0.23 & 4.1 & 7,311 & 368 & 5.0 & not set & ecoregion $^{3}$ \\
\hline Suspended solids & $4.0 \mathrm{mg} / \mathrm{L}$ & 38 & $<4.0$ & 8.0 & 17 & 42 & 1,480 & 7,286 & 652 & 8.9 & not set & not set \\
\hline Copper & $1.0 \mu \mathrm{g} / \mathrm{L}$ & 3.3 & $<1.0$ & 1.8 & 2.5 & 3.8 & 108 & 6,619 & 281 & 4.2 & $\begin{array}{c}25-33 \\
\mu \mathrm{g} / \mathrm{L}^{4}\end{array}$ & $9.0 \mu \mathrm{g} / \mathrm{L}$ \\
\hline Iron & $20 \mu \mathrm{g} / \mathrm{L}$ & 1,300 & 20 & 250 & 560 & 1,400 & 44,800 & 7,334 & 0 & 0 & not set & $1,000 \mu \mathrm{g} / \mathrm{L}$ \\
\hline Lead & $1.0 \mu \mathrm{g} / \mathrm{L}$ & 1.8 & $<1.0$ & $<1.0$ & $<1.0$ & 1.7 & 160 & 6,549 & 3,794 & 57.9 & $\begin{array}{c}6.7-9.5 \\
\mu g / L^{4}\end{array}$ & $2.5 \mu \mathrm{g} / \mathrm{L}$ \\
\hline Zinc & $6.0 \mu \mathrm{g} / \mathrm{L}$ & 19 & $<6.0$ & $<6.0$ & 8.6 & 17 & 730 & 7,279 & 2,521 & 34.6 & $\begin{array}{c}230-300 \\
\mu \mathrm{g} / \mathrm{L}^{4}\end{array}$ & $120 \mu \mathrm{g} / \mathrm{L}$ \\
\hline Chloride & $5.0 \mathrm{mg} / \mathrm{L}$ & 45 & 5.0 & 25 & 35 & 51 & 615 & 7,331 & 0 & 0 & $\begin{array}{c}414-467 \\
\mu \mathrm{g} / \mathrm{L}^{5}\end{array}$ & $230 \mu \mathrm{g} / \mathrm{L}$ \\
\hline Sulfate & $5.0 \mathrm{mg} / \mathrm{L}$ & 59 & 7.3 & 33 & 48 & 68 & 723 & 7,314 & 0 & 0 & $\begin{array}{c}1,678 \text { to } \\
2,059 \mathrm{mg} / \mathrm{L} \\
250 \mathrm{mg} / \mathrm{L} \\
(\text { POI) }\end{array}$ & not set \\
\hline Hardness & $30 \mathrm{mg} / \mathrm{L}$ & 287 & 37 & 243 & 293 & 333 & 643 & 7,345 & 0 & 0 & not set & not set \\
\hline Dissolved solids & $30 \mathrm{mg} / \mathrm{L}$ & 394 & 85 & 314 & 377 & 438 & 1,740 & 7,326 & 0 & 0 & $\begin{array}{c}750 \mathrm{mg} / \mathrm{L} \\
\text { (POI) }\end{array}$ & not set \\
\hline
\end{tabular}

\footnotetext{
${ }^{1}$ Indiana criteria are from the Indiana water-quality standards rules for surface water (Indiana Administrative Code, 2013).
}

${ }^{2}$ National criteria are from the national recommended fresh-water-quality criteria (U.S. Environmental Protection Agency, 2009 and references therein).

${ }^{3}$ The national recommended water-quality criteria for nutrients are listed by aggregate ecoregion (U.S. Environmental Protection Agency, 2000a, 2000b, and 2000c). The criteria for total nitrogen, including nitrate and organic nitrogen, are Cornbelt and Northern Great Plains $(2.18 \mathrm{mg} / \mathrm{L})$; Mostly Glaciated Dairy Region $(0.54 \mathrm{mg} / \mathrm{L})$; and Southeast Temperate Forested Plains and Hills $(0.69 \mathrm{mg} / \mathrm{L})$. The criteria for total phosphorus are Cornbelt and Northern Great Plains $(0.076 \mathrm{mg} / \mathrm{L})$; Mostly Glaciated Dairy Region $(0.033 \mathrm{mg} / \mathrm{L})$; and Southeast Temperate Forested Plains and Hills $(0.037 \mathrm{mg} / \mathrm{L})$.

${ }^{4}$ The Indiana water-quality standards rules for surface water (Indiana Administrative Code, 2013) provide an equation and a table for computing the dissolved concentration criteria for selected metals, based on the total recoverable metal concentration and a factor for the water hardness. For the dataset in this report, hardness values generally ranged from $243 \mathrm{mg} / \mathrm{L}$ (the 25 th percentile) to $333 \mathrm{mg} / \mathrm{L}$ (the 75th percentile), and the equivalent hardness factors applied from the Indiana rule are 250 and $350 \mathrm{mg} / \mathrm{L}$, respectively. The criteria are presented as a range computed with the two hardness factors.

${ }^{5}$ The Indiana water-quality standards rules for surface water (Indiana Administrative Code, 2013) provide an equation and a table for computing the chloride concentration criteria, based on factors for hardness and sulfate. For the dataset in this report, the hardness factors are 250 and $350 \mathrm{mg} / \mathrm{L}$ and the sulfate values generally ranged from $33 \mathrm{mg} / \mathrm{L}$ (the 25 th percentile) to $68 \mathrm{mg} / \mathrm{L}$ (the 75 th percentile); the equivalent sulfate factors are 25 and $50 \mathrm{mg} / \mathrm{L}$, respectively.

${ }^{6}$ The Indiana water-quality standards rules for surface water (Indiana Administrative Code, 2013) provide an equation and a table for computing the sulfate concentration criteria, based on factors for hardness and chloride. For the dataset in this report, the hardness factors are 250 and $350 \mathrm{mg} / \mathrm{L}$ and the chloride values generally ranged from $25 \mathrm{mg} / \mathrm{L}$ (the 25 th percentile) to $51 \mathrm{mg} / \mathrm{L}$ (the 75 th percentile); the equivalent chloride factors are 25 and $50 \mathrm{mg} / \mathrm{L}$, respectively. 


\section{EXPLANATION}

Mostly Glaciated Dairy Region

Cornbelt and Northern Great Plains

Southeast Temperate Forested Plains and Hills

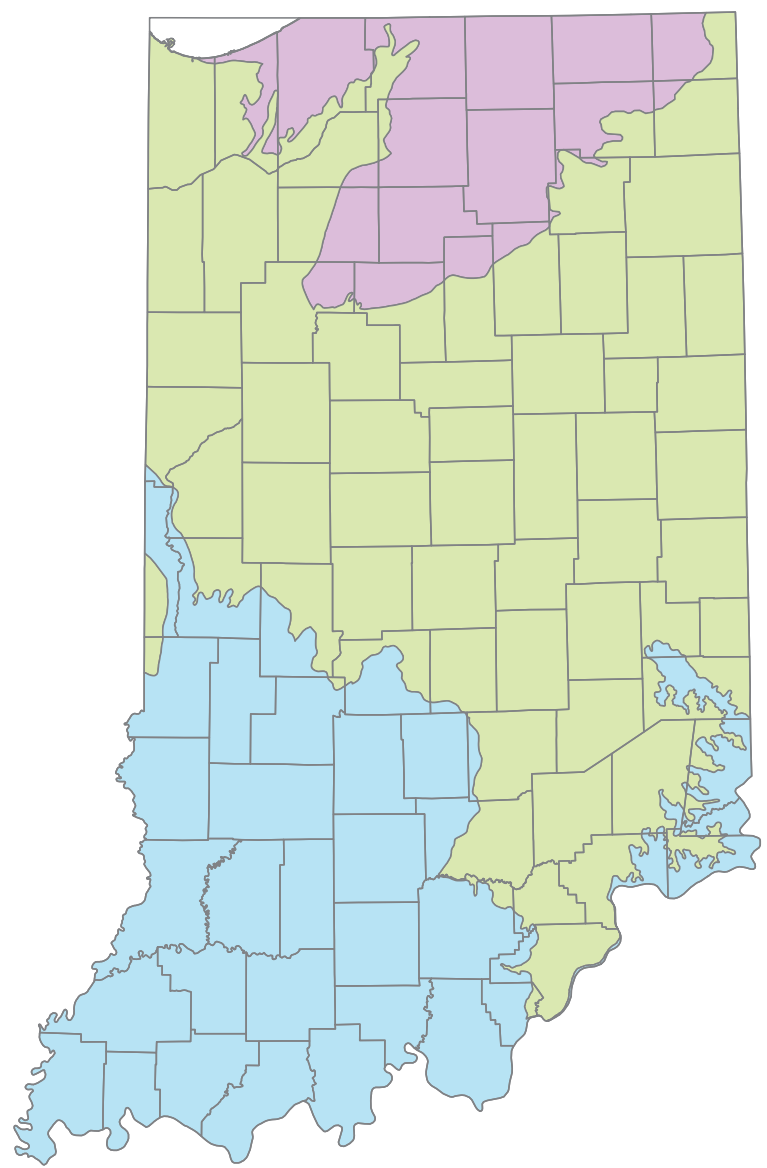

Figure 5. Aggregate ecoregions in Indiana.

(MGDR) for part of northern Indiana, and the Southeast Temperate Forested Plains and Hills (STFPH) for mostly southwestern Indiana (U.S. Environmental Protection Agency, 2000a, 2000b, and 2000c). The national recommended waterquality criteria for total nitrogen in rivers and streams are $2.18 \mathrm{mg} / \mathrm{L}$ for the CBNGP, $0.54 \mathrm{mg} / \mathrm{L}$ for the MGDR, and $0.69 \mathrm{mg} / \mathrm{L}$ for the STFPH. These criteria apply to the sum of nitrogen in the water, of which nitrate and organic nitrogen are parts. The national recommended water-quality criteria for phosphorus in rivers and streams are $0.076 \mathrm{mg} / \mathrm{L}$ for the CBNGP, $0.033 \mathrm{mg} / \mathrm{L}$ for the MGDR, and $0.037 \mathrm{mg} / \mathrm{L}$ for the STFPH.

Nutrient concentrations in this study generally were higher than standards and criteria (table 3 ). The national recommended criteria for total nitrogen in the ecoregions in Indiana were exceeded by more than one-half of the nitrate analyses in the study, since the statewide median nitrate concentration was $2.6 \mathrm{mg} / \mathrm{L}$, compared to the highest national criterion of $2.18 \mathrm{mg} / \mathrm{L}$ for the CBNGP in Indiana. The national recommended criteria for total phosphorus in the ecoregions in Indiana was exceeded in most of the phosphorus analyses in the study, since the 25th percentile of all concentrations was $0.07 \mathrm{mg} / \mathrm{L}$, compared to the highest national criterion of $0.076 \mathrm{mg} / \mathrm{L}$ for the CBNGP in Indiana.

Suspended solids are analyzed in water as the dry weight of sediment from a subsample of water. A total suspended solids concentration may equal a total suspended sediment concentration in which the entire sample is analyzed, especially when sand-size particles are more than 25 percent (Gray and others, 2000). However, total suspended solids is an approximation of suspended sediment and is descriptive of particulates and particulate-bound nutrient content in water. Neither an Indiana criterion nor a national recommended water-quality criterion is listed for suspended solids. 


\section{Metals}

Metals that commonly occur in water are elements that are found in the earth's crust, although they can be present in wastewater. The metals in this study were from analysis of total recoverable metals, rather than dissolved metals; the Indiana water-quality standards are for dissolved metals. The Indiana rule ${ }^{5}$ provides an equation and a table for computing the dissolved concentration criteria for selected metals, based on the total recoverable metal concentration and a factor for the water hardness. For the dataset in this report, hardness values generally ranged from $243 \mathrm{mg} / \mathrm{L}$ (the 25 th percentile) to $333 \mathrm{mg} / \mathrm{L}$ (the 75 th percentile) (table 3 ). The equivalent hardness values in the table from the Indiana rule are 250 and $350 \mathrm{mg} / \mathrm{L}$. Based on the hardness of 250 and $350 \mathrm{mg} / \mathrm{L},{ }^{6}$ a range of chronic aquatic criteria are listed for the total recoverable concentrations of the metals copper, lead, and zinc in this study.

Copper is used extensively by industry and is found in some wastewaters. Copper can be dissolved from water pipes and plumbing fixtures when water $\mathrm{pH}$ is less than 7. Copper is added to reservoirs, lakes, and ponds to slow the growth of algae. The Indiana chronic aquatic criterion for copper is 25 to 33 micrograms per liter $(\mu \mathrm{g} / \mathrm{L})$, to protect aquatic life from chronic toxic effects. The national recommended criterion continuous concentration for copper is $9.0 \mu \mathrm{g} / \mathrm{L}$.

Copper concentrations in this study exceeded the $33 \mu \mathrm{g} / \mathrm{L}$ upper end of the range of Indiana water-quality standards for this dataset in 14 samples $(0.2$ percent $)$. The maximum copper concentration was $108 \mu \mathrm{g} / \mathrm{L}$ and the 75 th percentile was $3.8 \mu \mathrm{g} / \mathrm{L}$, compared with the national recommended criterion of $9 \mu \mathrm{g} / \mathrm{L}$.

Iron is a metallic element abundant in the earth's crust and is essential for the metabolism of plants and animals. The solubility of iron in water is determined by oxidation-reduction conditions and $\mathrm{pH}$. Iron is present in organic wastes and wastewater from some industrial and manufacturing processes. The national recommended criterion continuous concentration is $1,000 \mu \mathrm{g} / \mathrm{L}$. A criterion for iron is not listed in the Indiana rules. Iron concentrations in this study exceeded the $1,000 \mu \mathrm{g} / \mathrm{L}$ national recommended criterion in less than one-half the analyses. The median was $560 \mu \mathrm{g} / \mathrm{L}$, and the 75th percentile was $1,400 \mu \mathrm{g} / \mathrm{L}$.

Lead can be released into the air from burning coal and smelting ores, and it was once an additive in gasoline. Wet and dry deposition of lead in the air has dispersed lead into the environment. Lead is used in batteries and other manufacturing and can be present in some wastewaters.

\footnotetext{
${ }^{5}$ Indiana Administrative Code (2013) tables 6-2 and 6-3 for most of Indiana and tables 8-1 and 8-2 for the Great Lakes system.

${ }^{6}$ One of the 10 drainage basins in this study (the Lake Michigan Basin) is part of the Great Lakes system. The median hardness for the Lake Michigan Basin was $380 \mathrm{mg} / \mathrm{L}$, equivalent to $400 \mathrm{mg} / \mathrm{L}$ in the table from the Indiana rules. For the Lake Michigan Basin, based on this hardness value, the criterion for copper is $29 \mu \mathrm{g} / \mathrm{L}$ and the criterion for zinc is $380 \mu \mathrm{g} / \mathrm{L}$. A separate criterion for lead in the Great Lakes system is not listed in the Indiana rules.
}

The Indiana chronic aquatic criterion for lead is 6.7 to $9.5 \mu \mathrm{g} / \mathrm{L}$, to protect aquatic life from chronic toxic effects. The national recommended criterion continuous concentration for lead is $2.5 \mu \mathrm{g} / \mathrm{L}$.

Lead concentrations in this study exceeded the $9.5 \mu \mathrm{g} / \mathrm{L}$ upper end of the range of Indiana water-quality standards for this dataset in 152 samples ( 2.3 percent). The maximum lead concentration was $160 \mu \mathrm{g} / \mathrm{L}$ and the 75 th percentile was $1.7 \mu \mathrm{g} / \mathrm{L}$, compared with the national recommended criterion of $2.5 \mu \mathrm{g} / \mathrm{L}$.

Zinc is about as abundant in the earth's crust as copper or nickel, but it is more soluble in water. Zinc is used in brass and bronze, for galvanizing steel, and in paint and rubber. It is widely dispersed in the aquatic environment. The Indiana chronic aquatic criterion for zinc is 230 to $300 \mu \mathrm{g} / \mathrm{L}$, to protect aquatic life from chronic toxic effects. For the Lake Michigan Basin in Indiana, the chronic aquatic criterion for zinc is $380 \mu \mathrm{g} / \mathrm{L}$. The national recommended criterion continuous concentration for zinc is $120 \mu \mathrm{g} / \mathrm{L}$.

Zinc concentrations in this study exceeded the $300 \mu \mathrm{g} / \mathrm{L}$ Indiana water-quality standard in 23 samples ( 0.3 percent). The maximum zinc concentration was $730 \mu \mathrm{g} / \mathrm{L}$, and the 75 th percentile was $17 \mu \mathrm{g} / \mathrm{L}$. The top 4 percent of zinc concentrations exceeded the national recommended criterion of $120 \mu \mathrm{g} / \mathrm{L}$.

\section{Ions and Dissolved Solids}

Ions are a group of constituents in this report that include the anions chloride, sulfate, and calcium carbonate hardness. Dissolved solids can be comprised of multiple ions.

Chloride is a major ion in water and the common ionic form of the element chlorine in water. Chlorine is used as a disinfectant for water and wastewater. Chloride salts are used to soften water and as road deicers. Deep subsurface water, such as water associated with oil and gas production, will have high chloride levels. The Indiana chronic aquatic criterion for chloride is set to protect aquatic life from chronic toxic effects. This chloride criterion is computed with an equation that includes hardness and sulfate concentration, and can be derived from a table in the Indiana rules ${ }^{7}$ by use of a procedure similar to that used for metals. For the dataset in this report, the hardness values for the chloride criteria table are 250 and $350 \mathrm{mg} / \mathrm{L}$. The data in this report have sulfate ranging from $33 \mathrm{mg} / \mathrm{L}$ (the 25 th percentile) to $68 \mathrm{mg} / \mathrm{L}$ (the 75 th percentile) (table 3 ). The equivalent sulfate values in the standards table are 25 and $50 \mathrm{mg} / \mathrm{L}$. Based on these values of hardness and sulfate, the chloride criteria range from 414 to $467 \mathrm{mg} / \mathrm{L}$. For the Lake Michigan Basin, the chloride criterion is $680 \mathrm{mg} / \mathrm{L}$. The criterion for chloride in water at the point of intake for

\footnotetext{
${ }^{7}$ Indiana Administrative Code (2013) has a table for computing the chloride chronic aquatic criterion in 327 IAC2-1-6(a)(5)(E) for most of Indiana. For the Great Lakes system, a median sulfate of $150 \mathrm{mg} / \mathrm{L}$ and hardness of $400 \mathrm{mg} / \mathrm{L}$ were used with table $8-2 \mathrm{~b}$ to compute the chloride aquatic criterion of $680 \mathrm{mg} / \mathrm{L}$.
} 
a public-water system in Indiana is $250 \mathrm{mg} / \mathrm{L}$. The national recommended water-quality criterion for chloride is $230 \mathrm{mg} / \mathrm{L}$.

Chloride concentrations in this study exceeded the $467 \mathrm{mg} / \mathrm{L}$ upper end of the range of Indiana water-quality standards for this dataset in 2 samples and exceeded $250 \mathrm{mg} / \mathrm{L}$ in 23 samples ( 0.3 percent). The maximum chloride concentration was $615 \mathrm{mg} / \mathrm{L}$, and the 75th percentile was $51 \mathrm{mg} / \mathrm{L}$.

Sulfate is a major ion in water and the common form of the element sulfur, often occurring as a complex ion with calcium or sodium. Sulfate levels are related to $\mathrm{pH}$, and sulfate may contribute to acidic water. Wet deposition of sulfate in the air contributes to acid rain; natural processes and human activity affect the levels of sulfate in streams. The chronic aquatic criterion for sulfate is set to protect aquatic life from chronic toxic effects. This sulfate criterion is computed with an equation that includes hardness and chloride concentration, and can be derived from a table in the Indiana rules ${ }^{8}$ by use of a procedure similar to that used for metals. For the dataset in this report, the hardness values for the sulfate criteria table are 250 and $350 \mathrm{mg} / \mathrm{L}$. The data in this report have chloride ranging from $25 \mathrm{mg} / \mathrm{L}$ (the 25 th percentile) to $51 \mathrm{mg} / \mathrm{L}$ (the 75th percentile) (table 3 ). The equivalent chloride values in the standards table are 25 and $50 \mathrm{mg} / \mathrm{L}$. Based on these values of hardness and chloride, the sulfate criteria range from 1,678 to $2,059 \mathrm{mg} / \mathrm{L}$. Sulfate criteria for water at the point of intake for a public-water system in Indiana is $250 \mathrm{mg} / \mathrm{L}$.

Sulfate concentrations in this study exceeded the $2,059 \mathrm{mg} / \mathrm{L}$ upper end of the range of Indiana water-quality standards for this dataset in no samples and exceeded $250 \mathrm{mg} / \mathrm{L}$ in 67 samples ( 0.9 percent). The maximum sulfate concentration was $723 \mathrm{mg} / \mathrm{L}$, and the 75 th percentile was $68 \mathrm{mg} / \mathrm{L}$.

Hardness is a term from the water-supply industry and comes from the metallic ions in the water, primarily calcium and magnesium. Hardness is generally the same as alkalinity, the ability of a solution to neutralize acid, and is represented as an equivalent of calcium carbonate. Hardness is dependent upon $\mathrm{pH}$ and affected by temperature. Natural processes and human activity affect the levels of hardness in streams. Hardness is important as a determinant of the potential for the solubility of some elements, such as metals. Some Indiana criteria, such as those for selected metals, chloride, and sulfate, are calculated with the water hardness, as described earlier in this report.

Dissolved solids include all the cations and anions in solution, which will be a different mixture in different water bodies. Excessive levels of dissolved solids are an indication of water pollution from various sources. The criterion for dissolved solids in water at the point of intake for a public-water system or point of withdrawal for an industrial water supply in Indiana is $750 \mathrm{mg} / \mathrm{L}$.

\footnotetext{
${ }^{8}$ Indiana Administrative Code (2013) has a table for computing the sulfate chronic aquatic criteria in 327 IAC2-1-6(a)(6)(C) for most of Indiana.
}

Dissolved solids concentrations in this study exceeded the $750 \mathrm{mg} / \mathrm{L}$ Indiana water-quality standard in 215 samples (2.9 percent). The maximum dissolved solids concentration was $1,740 \mathrm{mg} / \mathrm{L}$, and the 75 th percentile was $438 \mathrm{mg} / \mathrm{L}$.

\section{Major Drainage Basins}

The distribution of constituent concentrations among the 10 major drainage basins in Indiana was inspected by use of boxplots (fig. 6) and statistical analysis with the generalized Wilcoxon test (Helsel, 2004). The boxplots indicate whether the median concentration for the samples from a basin was higher or lower than the statewide median. Statistical analysis of the concentration distributions indicate basins that had a distribution significantly different from all other basins (indicated as a unique basin by an asterisk in the group label on fig. 6). Basins sharing the same group label (A, B, C, etc.) had concentration distributions that were not significantly different, and some basins belong to more than one group for some constituents. Basins with fewer sites had fewer samples but the statistical comparison was not biased by the number of samples per basin, which were more than 100 in all cases. Summary statistics for constituent concentrations, by basin (table 4), supplement the boxplots in figure 6 .

The two Lake Michigan Basin sites had concentrations that were significantly different from all other basins for 10 of the 12 constituents, with concentrations of constituents higher than the medians of other basins and many times higher than the statewide median. The two Ohio River Basin sites had concentrations that were significantly different from all other basins for 5 of the 12 constituents, with concentrations of constituents lower than the medians of other basins and lower than the statewide median. The Patoka River Basin site had concentrations that were significantly different from all other basins for 4 of the 12 constituents. A progression of increasing median concentrations was observed from the 16 Upper Wabash River Basin sites downstream to the 8 Middle Wabash River Basin sites and the single Lower Wabash River Basin site for phosphorus, organic nitrogen, suspended solids, copper, iron, and lead. The median values were generally similar within these three basins for the other constituents. Lead had the most censored values, followed by zinc. More than one-half of the concentrations for lead and zinc were censored in samples from sites in the Ohio, Whitewater, and East Fork White River Basins. 


\section{A. Nutrients and suspended solids}
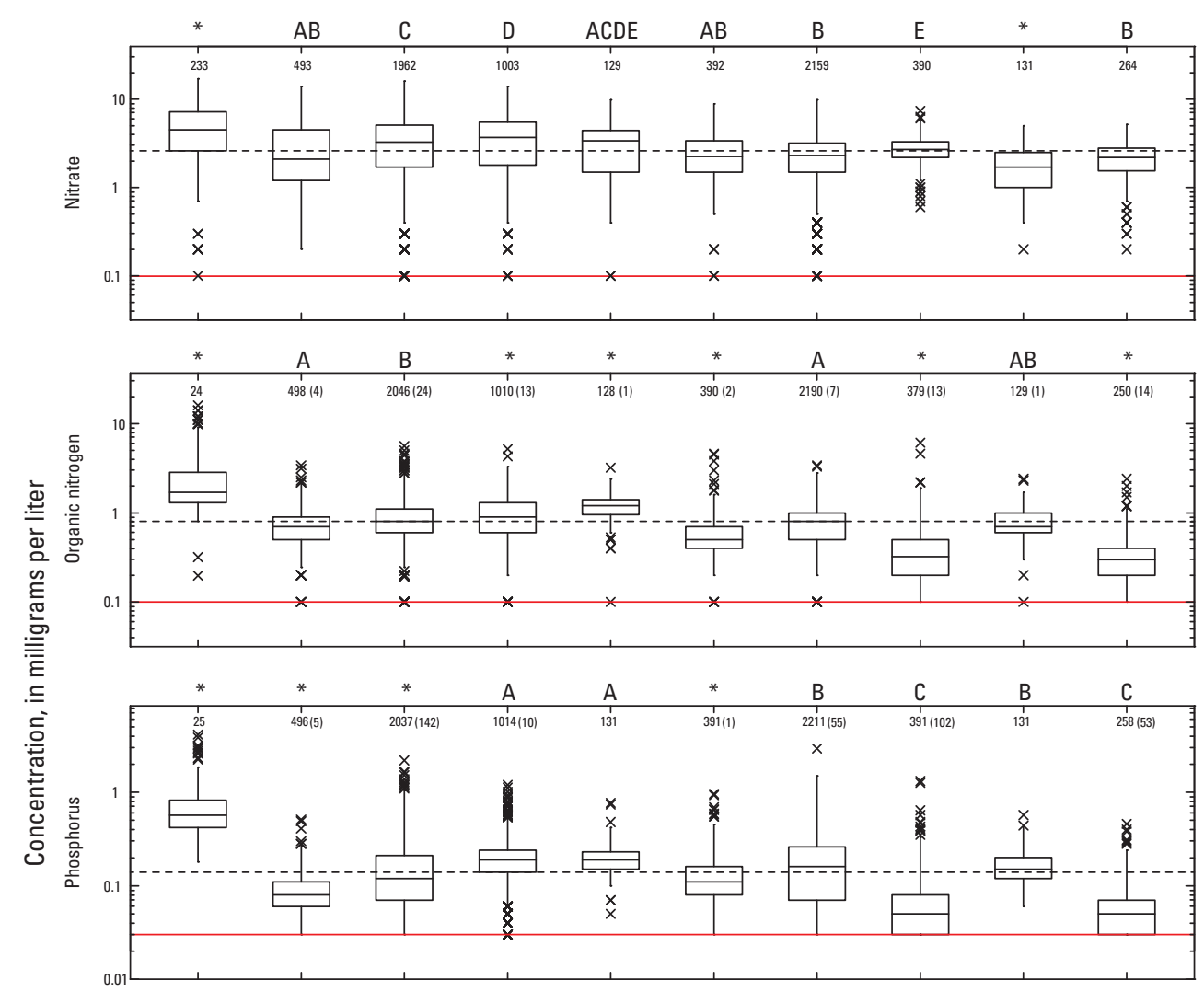

\section{EXPLANATION}

* Unique basin

300 Observations

(75) Number censored

Largest value less than

75th percentile +

$1.5 \mathrm{X}$ interquartile range
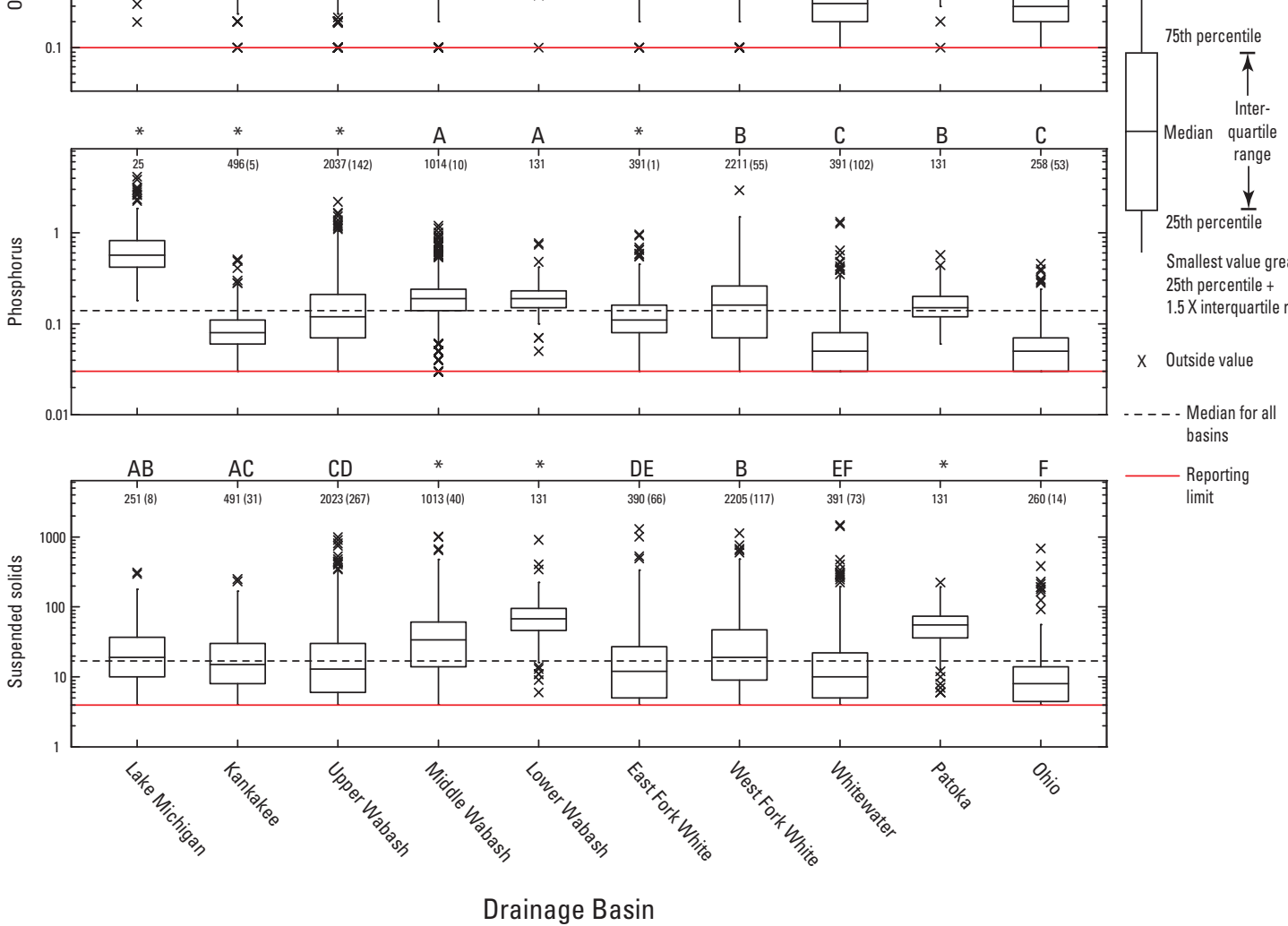

limit

Drainage Basin

Figure 6. Distributions of concentrations for each constituent, by drainage basin. $A$, Nutrients and suspended solids. $B$, Metals. $C$, lons and dissolved solids. 


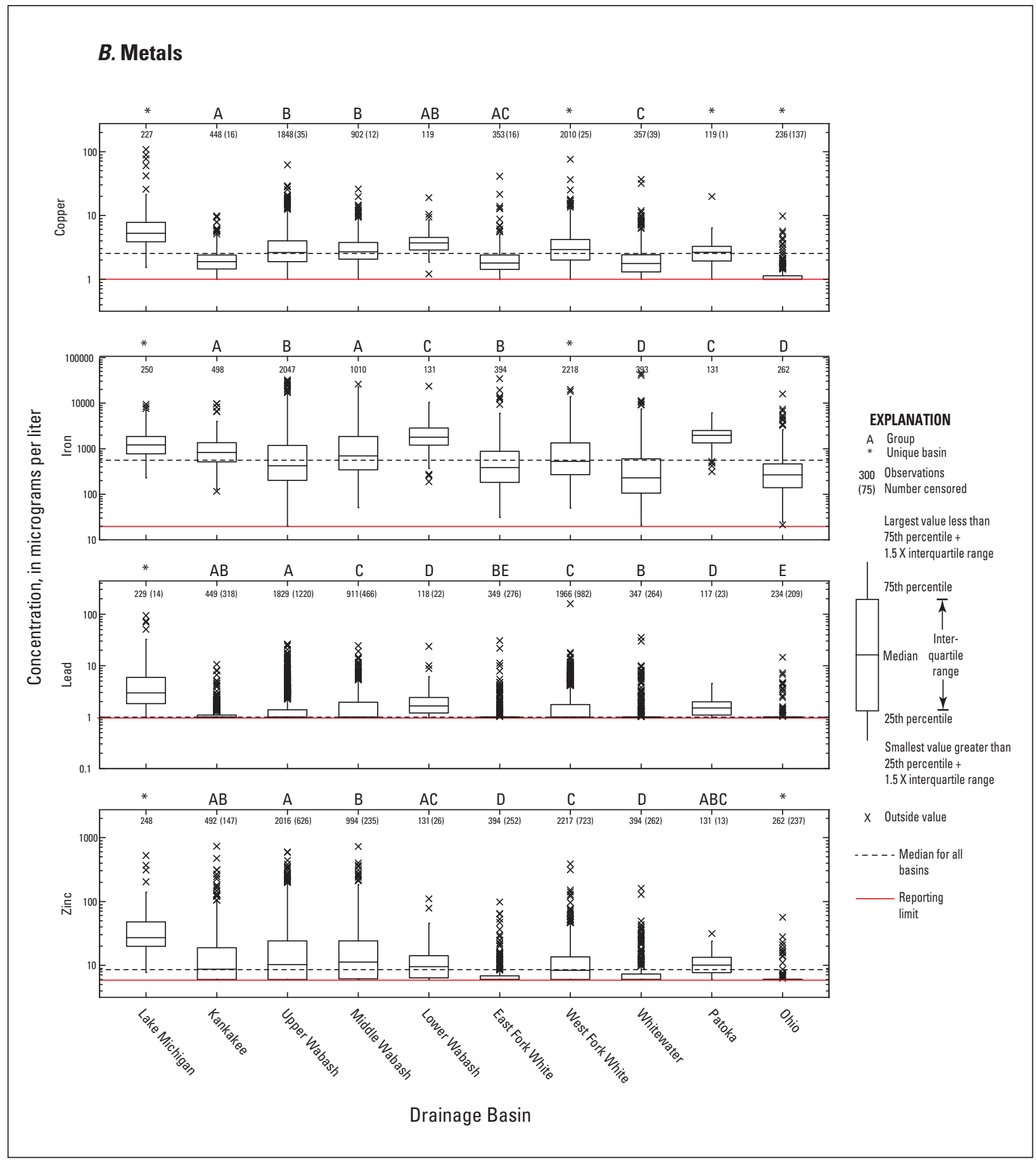

Figure 6. Distributions of concentrations for each constituent, by drainage basin. $A$, Nutrients and suspended solids. $B$,

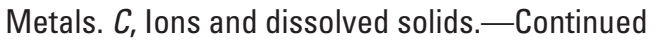




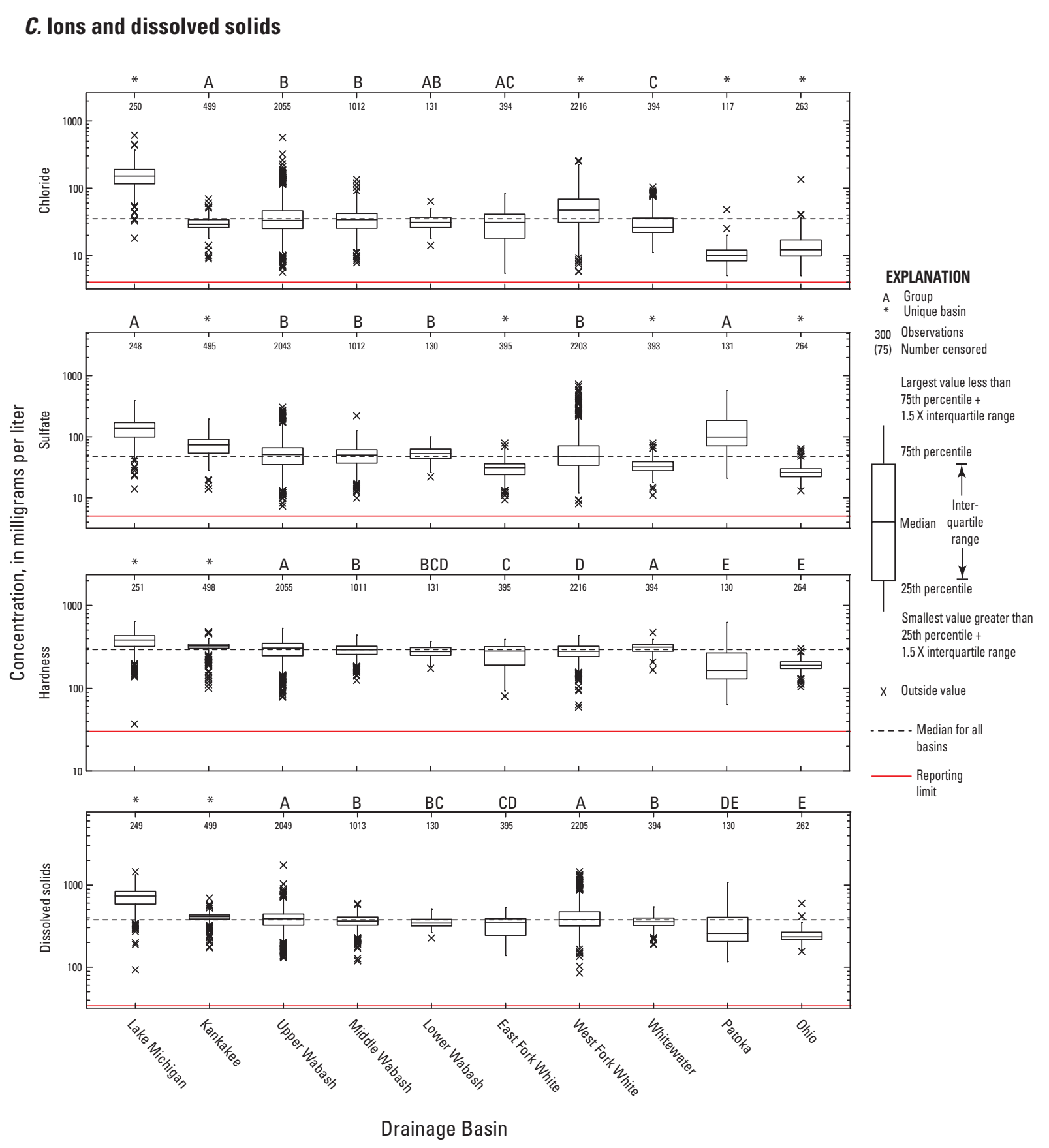

Figure 6. Distributions of concentrations for each constituent, by drainage basin. $A$, Nutrients and suspended solids. $B$, Metals. $C$, Ions and dissolved solids.-Continued 
Table 4. Summary statistics for constituent concentrations in Indiana streams, 2000-10, by drainage basin.

$[\mathrm{mg} / \mathrm{L}$, milligrams per liter; minimum non-censored value listed although some constituents have censored values less than the reporting limit as listed in table 3; n, number of samples; R., River; <, less than; $\mu \mathrm{g} / \mathrm{L}$, micrograms per liter]

\begin{tabular}{|c|c|c|c|c|c|c|c|}
\hline \multicolumn{8}{|c|}{ Nitrate } \\
\hline $\begin{array}{c}\text { Indiana } \\
\text { drainage basin }\end{array}$ & $\begin{array}{l}\text { Mean } \\
(\mathrm{mg} / \mathrm{L})\end{array}$ & $\begin{array}{c}\text { Minimum } \\
\text { (mg/L) }\end{array}$ & $\begin{array}{c}\text { 25th } \\
\text { percentile } \\
\text { (mg/L) }\end{array}$ & $\begin{array}{c}\text { Median } \\
\text { (mg/L) }\end{array}$ & $\begin{array}{c}\text { 75th } \\
\text { percentile } \\
\text { (mg/L) }\end{array}$ & $\begin{array}{c}\text { Maximum } \\
\text { (mg/L) }\end{array}$ & $\mathbf{n}$ \\
\hline Lake Michigan & 5.3 & 0.1 & 2.6 & 4.5 & 7.2 & 17.0 & 233 \\
\hline Kankakee R. & 3.2 & 0.2 & 1.2 & 2.1 & 4.5 & 14.0 & 493 \\
\hline Upper Wabash R. & 3.6 & 0.1 & 1.7 & 3.3 & 5.1 & 16.0 & 1,962 \\
\hline Middle Wabash R. & 3.9 & 0.1 & 1.8 & 3.7 & 5.5 & 14.0 & 1,003 \\
\hline Lower Wabash R. & 3.2 & 0.1 & 1.5 & 3.4 & 4.4 & 9.9 & 129 \\
\hline East Fork White R. & 2.5 & 0.1 & 1.5 & 2.3 & 3.4 & 8.9 & 392 \\
\hline West Fork White R. & 2.4 & 0.1 & 1.5 & 2.3 & 3.2 & 9.9 & 2,159 \\
\hline Whitewater R & 2.8 & 0.6 & 2.2 & 2.7 & 3.3 & 7.4 & 390 \\
\hline Patoka R. & 1.9 & 0.2 & 1.0 & 1.7 & 2.5 & 5.0 & 131 \\
\hline Ohio R. & 2.2 & 0.2 & 1.6 & 2.2 & 2.8 & 5.2 & 264 \\
\hline
\end{tabular}

\begin{tabular}{|c|c|c|c|c|c|c|c|c|c|}
\hline \multicolumn{10}{|c|}{ Organic nitrogen } \\
\hline $\begin{array}{c}\text { Indiana } \\
\text { drainage } \\
\text { basin }\end{array}$ & $\begin{array}{l}\text { Mean } \\
(\mathrm{mg} / \mathrm{L})\end{array}$ & $\begin{array}{c}\text { Minimum } \\
(\mathrm{mg} / \mathrm{L})\end{array}$ & $\begin{array}{c}\text { 25th } \\
\text { percentile } \\
\text { (mg/L) }\end{array}$ & $\begin{array}{c}\text { Median } \\
\text { (mg/L) }\end{array}$ & $\begin{array}{c}\text { 75th } \\
\text { percentile } \\
\text { (mg/L) }\end{array}$ & $\begin{array}{c}\text { Maximum } \\
\text { (mg/L) }\end{array}$ & $\mathbf{n}$ & $\begin{array}{l}\text { Number } \\
\text { censored }\end{array}$ & $\begin{array}{c}\text { Percent } \\
\text { censored }\end{array}$ \\
\hline Lake Michigan & 2.8 & 0.2 & 1.3 & 1.7 & 2.9 & 16.0 & 240 & 0 & 0 \\
\hline Kankakee R. & 0.8 & 0.2 & 0.5 & 0.7 & 0.9 & 3.4 & 498 & 4 & 0.8 \\
\hline Upper Wabash R. & 0.9 & 0.1 & 0.6 & 0.8 & 1.1 & 5.6 & 2,046 & 24 & 1.2 \\
\hline Middle Wabash R. & 1.0 & 0.1 & 0.6 & 0.9 & 1.3 & 5.2 & 1,010 & 13 & 1.3 \\
\hline Lower Wabash R. & 1.2 & 0.4 & 1.0 & 1.2 & 1.4 & 3.2 & 128 & 1 & 0.8 \\
\hline East Fork White R. & 0.6 & 0.1 & 0.4 & 0.5 & 0.7 & 4.6 & 390 & 2 & 0.5 \\
\hline West Fork White R. & 0.8 & 0.1 & 0.5 & 0.8 & 1.0 & 3.4 & 2,190 & 7 & 0.3 \\
\hline Whitewater R & 0.5 & 0.1 & 0.2 & 0.3 & 0.5 & 6.1 & 379 & 13 & 3.4 \\
\hline Patoka R. & 0.8 & 0.2 & 0.6 & 0.7 & 1.0 & 2.4 & 129 & 1 & 0.8 \\
\hline Ohio R. & 0.4 & 0.1 & 0.2 & 0.3 & 0.4 & 2.4 & 250 & 14 & 5.6 \\
\hline Total & & & & & & & 7,260 & 79 & 1.1 \\
\hline \multicolumn{10}{|c|}{ Phosphorus } \\
\hline $\begin{array}{l}\text { Indiana } \\
\text { drainage } \\
\text { basin }\end{array}$ & $\begin{array}{l}\text { Mean } \\
(\mathrm{mg} / \mathrm{L})\end{array}$ & $\begin{array}{c}\text { Minimum } \\
\text { (mg/L) }\end{array}$ & $\begin{array}{c}\text { 25th } \\
\text { percentile } \\
\text { (mg/L) }\end{array}$ & $\begin{array}{c}\text { Median } \\
\text { (mg/L) }\end{array}$ & $\begin{array}{c}\text { 75th } \\
\text { percentile } \\
\text { (mg/L) }\end{array}$ & $\begin{array}{c}\text { Maximum } \\
(\mathrm{mg} / \mathrm{L})\end{array}$ & $\mathbf{n}$ & $\begin{array}{l}\text { Number } \\
\text { censored }\end{array}$ & $\begin{array}{l}\text { Percent } \\
\text { censored }\end{array}$ \\
\hline Lake Michigan & 0.71 & 0.18 & 0.42 & 0.57 & 0.82 & 4.14 & 251 & 0 & 0 \\
\hline Kankakee R. & 0.09 & 0.03 & 0.06 & 0.08 & 0.11 & 0.51 & 496 & 5 & 1.0 \\
\hline Upper Wabash R. & 0.17 & 0.03 & 0.07 & 0.12 & 0.21 & 2.19 & 2,037 & 142 & 7.0 \\
\hline Middle Wabash R. & 0.21 & 0.03 & 0.14 & 0.19 & 0.24 & 1.2 & 1,014 & 10 & 1.0 \\
\hline Lower Wabash R. & 0.20 & 0.05 & 0.15 & 0.19 & 0.23 & 0.77 & 131 & 0 & 0 \\
\hline East Fork White R. & 0.14 & 0.03 & 0.08 & 0.11 & 0.16 & 0.96 & 391 & 1 & 0.3 \\
\hline West Fork White R. & 0.21 & 0.03 & 0.07 & 0.16 & 0.26 & 2.94 & 2,211 & 55 & 2.5 \\
\hline Whitewater R & 0.07 & 0.03 & $<0.03$ & 0.05 & 0.08 & 1.32 & 391 & 102 & 26.1 \\
\hline Patoka R. & 0.18 & 0.06 & 0.12 & 0.15 & 0.2 & 0.57 & 131 & 0 & 0 \\
\hline Ohio R. & 0.07 & 0.03 & 0.03 & 0.05 & 0.07 & 0.46 & 258 & 53 & 20.5 \\
\hline Total & & & & & & & 7,311 & 368 & 5.0 \\
\hline
\end{tabular}


Table 4. Summary statistics for constituent concentrations in Indiana streams, 2000-10, by drainage basin.-Continued

$[\mathrm{mg} / \mathrm{L}$, milligrams per liter; minimum non-censored value listed although some constituents have censored values less than the reporting limit as listed in table 3; n, number of samples; R., River; <, less than; $\mu \mathrm{g} / \mathrm{L}$, micrograms per liter]

\begin{tabular}{|c|c|c|c|c|c|c|c|c|c|}
\hline \multicolumn{10}{|c|}{ Suspended solids } \\
\hline $\begin{array}{l}\text { Indiana } \\
\text { drainage } \\
\text { basin }\end{array}$ & $\begin{array}{l}\text { Mean } \\
(\mathrm{mg} / \mathrm{L})\end{array}$ & $\begin{array}{l}\text { Minimum } \\
\text { (mg/L) }\end{array}$ & $\begin{array}{c}\text { 25th } \\
\text { percentile } \\
\text { (mg/L) }\end{array}$ & $\begin{array}{c}\text { Median } \\
\text { (mg/L) }\end{array}$ & $\begin{array}{c}\text { 75th } \\
\text { percentile } \\
\text { (mg/L) }\end{array}$ & $\begin{array}{c}\text { Maximum } \\
\text { (mg/L) }\end{array}$ & $\mathbf{n}$ & $\begin{array}{l}\text { Number } \\
\text { censored }\end{array}$ & $\begin{array}{c}\text { Percent } \\
\text { censored }\end{array}$ \\
\hline Lake Michigan & 31 & 4.0 & 10 & 19 & 37 & 312 & 251 & 8 & 3.2 \\
\hline Kankakee R. & 23 & 4.0 & 8 & 15 & 30 & 250 & 491 & 31 & 6.3 \\
\hline Upper Wabash R. & 29 & 4.0 & 6 & 13 & 30 & 1,000 & 2,023 & 267 & 13.2 \\
\hline Middle Wabash R. & 51 & 4.0 & 14 & 34 & 61 & 1,020 & 1,013 & 40 & 3.9 \\
\hline Lower Wabash R. & 86 & 6.0 & 46 & 68 & 95 & 912 & 131 & 0 & 0 \\
\hline East Fork White R. & 27 & 4.0 & 5 & 12 & 27 & 1,300 & 390 & 66 & 16.9 \\
\hline West Fork White R. & 41 & 4.0 & 9 & 19 & 47 & 1,130 & 2,205 & 117 & 5.3 \\
\hline Whitewater R & 28 & 4.0 & 5 & 10 & 22 & 1,480 & 391 & 73 & 18.7 \\
\hline Patoka R. & 62 & 6.0 & 36 & 55 & 74 & 224 & 131 & 0 & 0 \\
\hline Ohio R. & 15 & 4.0 & 5 & 8 & 14 & 688 & 260 & 50 & 19.2 \\
\hline Total & & & & & & & 7,286 & 652 & 8.9 \\
\hline \multicolumn{10}{|c|}{ Copper } \\
\hline $\begin{array}{l}\text { Indiana } \\
\text { drainage } \\
\text { basin }\end{array}$ & $\begin{array}{l}\text { Mean } \\
(\mu g / L)\end{array}$ & $\begin{array}{l}\text { Minimum } \\
\text { ( } \mu \mathrm{g} / \mathrm{L})\end{array}$ & $\begin{array}{c}\text { 25th } \\
\text { percentile } \\
(\mu \mathrm{g} / \mathrm{L})\end{array}$ & $\begin{array}{c}\text { Median } \\
\text { ( } \mu \mathrm{g} / \mathrm{L})\end{array}$ & $\begin{array}{c}\text { 75th } \\
\text { percentile } \\
(\mu \mathrm{g} / \mathrm{L})\end{array}$ & $\begin{array}{c}\text { Maximum } \\
(\mu \mathrm{g} / \mathrm{L})\end{array}$ & $\mathbf{n}$ & $\begin{array}{l}\text { Number } \\
\text { censored }\end{array}$ & $\begin{array}{c}\text { Percent } \\
\text { censored }\end{array}$ \\
\hline Lake Michigan & 7.2 & 1.5 & 3.9 & 5.2 & 7.8 & 108.0 & 227 & 0 & 0 \\
\hline Kankakee R. & 2.1 & 1.0 & 1.5 & 1.9 & 2.4 & 9.9 & 448 & 16 & 3.6 \\
\hline Upper Wabash R. & 3.4 & 1.0 & 1.9 & 2.6 & 4.0 & 62.1 & 1,848 & 35 & 1.9 \\
\hline Middle Wabash R. & 3.2 & 1.0 & 2.1 & 2.7 & 3.8 & 25.9 & 902 & 12 & 1.3 \\
\hline Lower Wabash R. & 4.0 & 1.2 & 2.9 & 3.7 & 4.5 & 19.0 & 119 & 0 & 0 \\
\hline East Fork White R. & 2.2 & 1.0 & 1.4 & 1.8 & 2.4 & 41.0 & 353 & 16 & 4.5 \\
\hline West Fork White R. & 3.4 & 1.0 & 2.0 & 2.9 & 4.2 & 76.0 & 2,010 & 25 & 1.2 \\
\hline Whitewater R & 2.3 & 1.0 & 1.3 & 1.8 & 2.4 & 36.7 & 357 & 39 & 10.9 \\
\hline Patoka R. & 2.9 & 1.1 & 1.9 & 2.6 & 3.3 & 19.8 & 119 & 1 & 0.8 \\
\hline Ohio R. & 1.0 & 1.0 & $<1.0$ & $<1.0$ & 1.1 & 9.8 & 236 & 137 & 58.1 \\
\hline Total & & & & & & & 6,619 & 281 & 4.2 \\
\hline
\end{tabular}

\begin{tabular}{lccccccr}
\hline \multicolumn{1}{c}{$\begin{array}{c}\text { Indiana } \\
\text { drainage } \\
\text { basin }\end{array}$} & $\begin{array}{c}\text { Mean } \\
(\mu \mathbf{g} / \mathbf{L})\end{array}$ & $\begin{array}{c}\text { Minimum } \\
(\boldsymbol{\mu g} / \mathbf{L})\end{array}$ & $\begin{array}{c}\text { 25th } \\
\text { percentile } \\
(\boldsymbol{\mu g} / \mathbf{L})\end{array}$ & $\begin{array}{c}\text { Median } \\
(\boldsymbol{\mu g} / \mathbf{L})\end{array}$ & $\begin{array}{c}\text { 75th } \\
\text { percentile } \\
(\boldsymbol{\mu g} / \mathbf{L})\end{array}$ & $\begin{array}{c}\text { Maximum } \\
(\boldsymbol{\mu g} / \mathbf{L})\end{array}$ & $\mathbf{n}$ \\
\hline Lake Michigan & 1.58 & 0.23 & 0.78 & 1.21 & 1.85 & 9.46 & 250 \\
Kankakee R. & 1.09 & 0.12 & 0.52 & 0.83 & 1.36 & 9.79 & 498 \\
Upper Wabash R. & 1.35 & 0.02 & 0.20 & 0.42 & 1.18 & 32.60 & 2,047 \\
Middle Wabash R. & 1.52 & 0.05 & 0.35 & 0.70 & 1.86 & 26.10 & 1,010 \\
Lower Wabash R. & 2.40 & 0.19 & 1.20 & 1.79 & 2.85 & 23.50 & 131 \\
East Fork White R. & 0.97 & 0.03 & 0.18 & 0.39 & 0.88 & 34.50 & 394 \\
West Fork White R. & 1.14 & 0.05 & 0.27 & 0.53 & 1.34 & 19.90 & 2,218 \\
Whitewater R & 0.99 & 0.02 & 0.11 & 0.23 & 0.60 & 44.80 & 393 \\
Patoka R. & 2.11 & 0.31 & 1.34 & 1.96 & 2.50 & 6.08 & 131 \\
Ohio R. & 0.57 & 0.02 & 0.14 & 0.27 & 0.46 & 15.90 & 262 \\
\hline & & & & & & & 7,334
\end{tabular}


Table 4. Summary statistics for constituent concentrations in Indiana streams, 2000-10, by drainage basin.-Continued

$[\mathrm{mg} / \mathrm{L}$, milligrams per liter; minimum non-censored value listed although some constituents have censored values less than the reporting limit as listed in table 3; n, number of samples; R., River; <, less than; $\mu \mathrm{g} / \mathrm{L}$, micrograms per liter]

\begin{tabular}{|c|c|c|c|c|c|c|c|c|c|}
\hline \multicolumn{10}{|c|}{ Lead } \\
\hline $\begin{array}{l}\text { Indiana } \\
\text { drainage } \\
\text { basin }\end{array}$ & $\begin{array}{l}\text { Mean } \\
(\mu \mathrm{g} / \mathrm{L})\end{array}$ & $\begin{array}{c}\text { Minimum } \\
(\mu \mathrm{g} / \mathrm{L})\end{array}$ & $\begin{array}{c}\text { 25th } \\
\text { percentile } \\
(\mu \mathrm{g} / \mathrm{L})\end{array}$ & $\begin{array}{c}\text { Median } \\
(\mu \mathrm{g} / \mathrm{L})\end{array}$ & $\begin{array}{c}\text { 75th } \\
\text { percentile } \\
\text { ( } \mu \mathrm{g} / \mathrm{L})\end{array}$ & $\begin{array}{c}\text { Maximum } \\
(\mu \mathrm{g} / \mathrm{L})\end{array}$ & $\mathbf{n}$ & $\begin{array}{l}\text { Number } \\
\text { censored }\end{array}$ & $\begin{array}{l}\text { Percent } \\
\text { censored }\end{array}$ \\
\hline Lake Michigan & 5.1 & 1.0 & 1.8 & 3.0 & 5.9 & 94.0 & 229 & 14 & 6.1 \\
\hline Kankakee R. & $<1.0$ & 1.0 & $<1.0$ & $<1.0$ & 1.1 & 318.0 & 449 & 318 & 70.8 \\
\hline Upper Wabash R. & 1.3 & 1.0 & $<1.0$ & $<1.0$ & 1.4 & 26.2 & 1,829 & 1,220 & 66.7 \\
\hline Middle Wabash R. & 1.6 & 1.0 & $<1.0$ & $<1.0$ & 1.9 & 24.6 & 911 & 466 & 51.2 \\
\hline Lower Wabash R. & 2.1 & 1.0 & 1.2 & 1.7 & 2.4 & 23.7 & 118 & 22 & 18.6 \\
\hline East Fork White R. & $<1.0$ & 1.0 & $<1.0$ & $<1.0$ & $<1.0$ & 30.7 & 349 & 276 & 79.1 \\
\hline West Fork White R. & 1.5 & 1.0 & $<1.0$ & $<1.0$ & 1.8 & 160.0 & 1,966 & 982 & 49.9 \\
\hline Whitewater R & 1.1 & 1.0 & $<1.0$ & $<1.0$ & $<1.0$ & 35.5 & 347 & 264 & 76.1 \\
\hline Patoka R. & 1.7 & 1.0 & 1.1 & 1.5 & 2.0 & 4.5 & 117 & 23 & 19.7 \\
\hline Ohio R. & $<1.0$ & 1.0 & $<1.0$ & $<1.0$ & $<1.0$ & 14.6 & 234 & 209 & 89.3 \\
\hline Tota & & & & & & & 6,549 & 3,794 & 57.9 \\
\hline
\end{tabular}

\begin{tabular}{|c|c|c|c|c|c|c|c|c|c|}
\hline \multicolumn{10}{|c|}{ Zinc } \\
\hline $\begin{array}{l}\text { Indiana } \\
\text { drainage } \\
\text { basin }\end{array}$ & $\begin{array}{l}\text { Mean } \\
(\mu g / L)\end{array}$ & $\begin{array}{c}\text { Minimum } \\
(\mu \mathrm{g} / \mathrm{L})\end{array}$ & $\begin{array}{c}\text { 25th } \\
\text { percentile } \\
(\mu \mathrm{g} / \mathrm{L})\end{array}$ & $\begin{array}{c}\text { Median } \\
\text { ( } \mu \mathrm{g} / \mathrm{L})\end{array}$ & $\begin{array}{c}\text { 75th } \\
\text { percentile } \\
(\mu \mathrm{g} / \mathrm{L})\end{array}$ & $\begin{array}{c}\text { Maximum } \\
(\mu \mathrm{g} / \mathrm{L})\end{array}$ & $\mathbf{n}$ & $\begin{array}{l}\text { Number } \\
\text { censored }\end{array}$ & $\begin{array}{c}\text { Percent } \\
\text { censored }\end{array}$ \\
\hline Lake Michigan & 38.3 & 7.7 & 19.9 & 27.2 & 48.1 & 524.0 & 248 & 0 & 0 \\
\hline Kankakee R. & 20.8 & 6.0 & 4.4 & 8.7 & 18.9 & 730.0 & 492 & 147 & 29.9 \\
\hline Upper Wabash R. & 24.5 & 6.0 & 4.6 & 10.3 & 24.1 & 596.0 & 2,016 & 626 & 31.1 \\
\hline Middle Wabash R. & 22.8 & 6.0 & 6.2 & 11.2 & 24.2 & 725.0 & 994 & 235 & 23.6 \\
\hline Lower Wabash R. & 12.3 & 6.0 & 6.4 & 9.6 & 14.1 & 110.0 & 131 & 26 & 19.8 \\
\hline East Fork White R. & 5.9 & 6.0 & 2.5 & 4.3 & 6.9 & 98.3 & 394 & 252 & 64.0 \\
\hline West Fork White R. & 11.0 & 6.0 & 5.1 & 8.4 & 13.6 & 389.0 & 2,217 & 723 & 32.6 \\
\hline Whitewater R & 6.4 & 6.0 & 1.9 & 3.8 & 7.3 & 161.0 & 394 & 262 & 66.5 \\
\hline Patoka R. & 10.9 & 6.1 & 7.7 & 10.1 & 13.4 & 31.4 & 131 & 13 & 9.9 \\
\hline Ohio R. & $<6.0$ & 6.3 & $<6.0$ & $<6.0$ & $<6.0$ & 56.5 & 262 & 237 & 90.5 \\
\hline Tota & & & & & & & 7,279 & 2,521 & 34.6 \\
\hline
\end{tabular}

\begin{tabular}{lccccccr}
\hline \multicolumn{1}{c}{$\begin{array}{c}\text { Indiana } \\
\text { drainage } \\
\text { basin }\end{array}$} & $\begin{array}{c}\text { Mean } \\
\text { (mg/L) }\end{array}$ & $\begin{array}{c}\text { Minimum } \\
\text { (mg/L) }\end{array}$ & $\begin{array}{c}\text { 25th } \\
\text { percentile } \\
\text { (mg/L) }\end{array}$ & $\begin{array}{c}\text { Median } \\
\text { (mg/L) }\end{array}$ & $\begin{array}{c}\text { 75th } \\
\text { percentile } \\
\text { (mg/L) }\end{array}$ & $\begin{array}{c}\text { Maximum } \\
\text { (mg/L) }\end{array}$ & n \\
\hline Lake Michigan & 158 & 18 & 116 & 152 & 190 & 615 & 250 \\
Kankakee R. & 30 & 9 & 26 & 29 & 34 & 69 & 499 \\
Upper Wabash R. & 40 & 6 & 25 & 33 & 46 & 570 & 2,055 \\
Middle Wabash R. & 34 & 8 & 25 & 34 & 42 & 135 & 1,012 \\
Lower Wabash R. & 32 & 14 & 26 & 31 & 37 & 64 & 131 \\
East Fork White R. & 31 & 5 & 18 & 31 & 41 & 82 & 394 \\
West Fork White R. & 55 & 6 & 31 & 47 & 69 & 260 & 2,216 \\
Whitewater R & 33 & 11 & 22 & 26 & 36 & 103 & 394 \\
Patoka R. & 11 & 5 & 8 & 10 & 12 & 48 & 117 \\
Ohio R. & 14 & 5 & 10 & 12 & 17 & 135 & 263 \\
\hline & & & & & & & 7,331
\end{tabular}


Table 4. Summary statistics for constituent concentrations in Indiana streams, 2000-10, by drainage basin.-Continued

[mg/L, milligrams per liter; minimum non-censored value listed although some constituents have censored values less than the reporting limit as listed in table 3; n, number of samples; R., River; <, less than; $\mu \mathrm{g} / \mathrm{L}$, micrograms per liter]

\begin{tabular}{lccccccr}
\hline \multicolumn{1}{c}{$\begin{array}{c}\text { Indiana } \\
\text { drainage } \\
\text { basin }\end{array}$} & $\begin{array}{c}\text { Mean } \\
\text { (mg/L) }\end{array}$ & $\begin{array}{c}\text { Minimum } \\
\text { (mg/L) }\end{array}$ & $\begin{array}{c}\text { 25th } \\
\text { percentile } \\
\text { (mg/L) }\end{array}$ & $\begin{array}{c}\text { Median } \\
\text { (mg/L) }\end{array}$ & $\begin{array}{c}\text { 75th } \\
\text { percentile } \\
\text { (mg/L) }\end{array}$ & $\begin{array}{c}\text { Maximum } \\
\text { (mg/L) }\end{array}$ & n \\
\hline Lake Michigan & 142 & 14 & 99 & 137 & 172 & 388 & 248 \\
Kankakee R. & 74 & 14 & 54 & 73 & 91 & 194 & 495 \\
Upper Wabash R. & 55 & 7 & 35 & 51 & 66 & 305 & 2,043 \\
Middle Wabash R. & 50 & 10 & 37 & 50 & 61 & 220 & 1,012 \\
Lower Wabash R. & 54 & 22 & 44 & 53 & 63 & 100 & 130 \\
East Fork White R. & 31 & 9 & 24 & 31 & 36 & 79 & 395 \\
West Fork White R. & 63 & 8 & 34 & 48 & 71 & 723 & 2,203 \\
Whitewater R & 35 & 11 & 28 & 32 & 39 & 79 & 393 \\
Patoka R. & 136 & 21 & 71 & 99 & 185 & 580 & 131 \\
Ohio R. & 27 & 13 & 22 & 26 & 30 & 64 & 264 \\
\hline
\end{tabular}

\begin{tabular}{|c|c|c|c|c|c|c|c|}
\hline \multicolumn{8}{|c|}{ Hardness } \\
\hline $\begin{array}{l}\text { Indiana } \\
\text { drainage } \\
\text { basin }\end{array}$ & $\begin{array}{l}\text { Mean } \\
(\mathrm{mg} / \mathrm{L})\end{array}$ & $\begin{array}{c}\text { Minimum } \\
\text { (mg/L) }\end{array}$ & $\begin{array}{c}\text { 25th } \\
\text { percentile } \\
\text { (mg/L) }\end{array}$ & $\begin{array}{c}\text { Median } \\
\text { (mg/L) }\end{array}$ & $\begin{array}{c}\text { 75th } \\
\text { percentile } \\
\text { (mg/L) }\end{array}$ & $\begin{array}{c}\text { Maximum } \\
\text { (mg/L) }\end{array}$ & $\mathbf{n}$ \\
\hline Lake Michigan & 370 & 37 & 319 & 383 & 432 & 643 & 251 \\
\hline Kankakee R. & 318 & 100 & 303 & 324 & 341 & 477 & 498 \\
\hline Upper Wabash R. & 296 & 78 & 246 & 304 & 347 & 530 & 2,055 \\
\hline Middle Wabash R. & 287 & 124 & 257 & 291 & 321 & 435 & 1,011 \\
\hline Lower Wabash R. & 276 & 174 & 249 & 277 & 308 & 367 & 131 \\
\hline East Fork White R. & 256 & 80 & 190 & 282 & 317 & 390 & 395 \\
\hline West Fork White R. & 280 & 59 & 241 & 279 & 321 & 430 & 2,216 \\
\hline Whitewater R & 308 & 167 & 279 & 314 & 337 & 468 & 394 \\
\hline Patoka R. & 206 & 64 & 129 & 165 & 266 & 623 & 130 \\
\hline Ohio R. & 191 & 104 & 174 & 189 & 208 & 303 & 264 \\
\hline Total & & & & & & & 7,345 \\
\hline \multicolumn{8}{|c|}{ Dissolved solids } \\
\hline $\begin{array}{l}\text { Indiana } \\
\text { drainage } \\
\text { basin }\end{array}$ & $\begin{array}{l}\text { Mean } \\
(\mathrm{mg} / \mathrm{L})\end{array}$ & $\begin{array}{c}\text { Minimum } \\
\text { (mg/L) }\end{array}$ & $\begin{array}{c}\text { 25th } \\
\text { percentile } \\
\text { (mg/L) }\end{array}$ & $\begin{array}{c}\text { Median } \\
\text { (mg/L) }\end{array}$ & $\begin{array}{c}\text { 75th } \\
\text { percentile } \\
\text { (mg/L) }\end{array}$ & $\begin{array}{c}\text { Maximum } \\
\text { (mg/L) }\end{array}$ & $\mathbf{n}$ \\
\hline Lake Michigan & 718 & 93 & 589 & 731 & 839 & 1,450 & 249 \\
\hline Kankakee R. & 407 & 173 & 386 & 411 & 433 & 693 & 499 \\
\hline Upper Wabash R. & 393 & 130 & 323 & 389 & 443 & 1,740 & 2,049 \\
\hline Middle Wabash R. & 365 & 120 & 324 & 366 & 406 & 595 & 1,013 \\
\hline Lower Wabash R. & 351 & 227 & 317 & 345 & 382 & 505 & 130 \\
\hline East Fork White R. & 322 & 138 & 245 & 346 & 388 & 530 & 395 \\
\hline West Fork White R. & 413 & 85 & 318 & 381 & 472 & 1,450 & 2,205 \\
\hline Whitewater R & 362 & 188 & 321 & 358 & 396 & 542 & 394 \\
\hline Patoka R. & 315 & 117 & 205 & 258 & 404 & 1,076 & 130 \\
\hline Ohio R. & 243 & 156 & 216 & 235 & 266 & 595 & 262 \\
\hline Total & & & & & & & 7,326 \\
\hline
\end{tabular}




\section{Trends in Concentrations}

Statistically significant trends in constituent concentrations have been summarized statewide and geographically. Increases and decreases in concentrations over time are described as the numerical difference and percentage difference in median flow-adjusted concentrations from 2000 compared with 2010. Where appropriate, general observations about non-significant increases and decreases have been added. A total of 684 trend analyses were made and 250 statistically significant trends were identified167 downward trends and 83 upward trends.

\section{Nutrients and Suspended Solids}

Nitrate concentrations showed significant trends at 16 sites (figs. 7 and 1-1). Upward trends of 24.7 to 42.6 percent $(0.3$ to $1.3 \mathrm{mg} / \mathrm{L})$ were identified at three sites in the West Fork White River Basin upstream from and inside the Indianapolis area. Downward trends were identified at 13 sites in 5 basins in the northern two-thirds of Indiana and ranged from -13.1 to -54.9 percent $(-0.3$ to $-3.8 \mathrm{mg} / \mathrm{L})$. When significant trends and non-significant changes in nitrate concentrations are considered, 74 percent of sites showed a decrease.

Organic nitrogen concentrations showed significant trends at 15 sites (figs. 7 and 1-2). Upward trends were identified at 10 sites in 5 basins, including 3 sites in the Kankakee River Basin and 3 sites in the Upper Wabash River Basin. Most of these upward trends ranged from 14 to 48 percent ( 0.1 to $0.2 \mathrm{mg} / \mathrm{L}$ ) except for one Lake Michigan Basin site, which increased by 182 percent $(3.1 \mathrm{mg} / \mathrm{L})$. Downward trends of -16.4 to -28.0 percent $(-0.1$ to $-0.4 \mathrm{mg} / \mathrm{L})$ were identified at five sites in four basins. When significant trends and non-significant changes in organic nitrogen concentrations are considered, 53 percent of sites showed an increase.

Phosphorus concentrations showed significant trends at 16 sites (fig. 7 and 1-3). Upward trends of 21.7 to 28.1 percent ( 0.02 to $0.07 \mathrm{mg} / \mathrm{L}$ ) were identified at one site in the Upper Wabash River Basin and at three sites in the West Fork White River Basin upstream from and inside the Indianapolis area. Downward trends of -14.1 to -38.7 percent $(-0.02$ to $-0.07 \mathrm{mg} / \mathrm{L})$ were identified at 12 sites in 7 basins statewide. When significant trends and non-significant changes in phosphorus concentrations are considered, 58 percent of sites showed a decrease.

Suspended solids concentrations showed significant trends at 13 sites (figs. 7 and 1-4). Upward trends of 34.9 to 91.0 percent $(5.4$ to $17.8 \mathrm{mg} / \mathrm{L}$ ) were identified at three sites in the Middle Wabash River Basin and one site in the West Fork White River Basin. Downward trends of -27.6 to -50.3 percent $(-2.9$ to $-20.5 \mathrm{mg} / \mathrm{L})$ were identified at nine sites in six basins. When significant trends and nonsignificant changes in suspended solids concentrations are considered, 68 percent of sites showed a decrease.

\section{Metals}

Copper concentrations showed significant trends at 24 sites (figs. 8 and 1-5). Upward trends of 3.7 to 78.8 percent ( 0.04 to $2.1 \mu \mathrm{g} / \mathrm{L}$ ) were identified at 13 sites in 6 basins. Copper increased at six sites in the Upper Wabash River Basin. Downward trends of -17.5 to -35.9 percent $(-0.04$ to $-1.7 \mu \mathrm{g} / \mathrm{L})$ were identified at 11 sites in 4 basins. Copper decreased at seven sites in the West Fork White River Basin. When significant trends and non-significant changes in copper concentrations are considered, 53 percent of sites showed an increase.

Iron concentrations showed significant trends at 19 sites (figs. 8 and 1-6). Upward trends of 30.1 and 101.3 percent $(119.6$ and $640.4 \mu \mathrm{g} / \mathrm{L})$ were identified at two sites in two basins. Downward trends of -22.2 to -56.0 percent $(-65.4$ to $-949.8 \mu \mathrm{g} / \mathrm{L})$ were identified at 17 sites in 8 basins. Iron decreased at eight sites in the West Fork White River Basin. When significant trends and non-significant changes in iron concentrations are considered, 77 percent of sites showed a decrease.

Lead concentrations showed significant trends at 17 sites (figs. 8 and $1-7)^{9}$. Upward trends of 2.2 to 26.0 percent $(0.02$ to $0.27 \mu \mathrm{g} / \mathrm{L})$ were identified at nine sites in five basins. Downward trends of -1.1 to -39.1 percent $(-0.01$ to $-1.2 \mu \mathrm{g} / \mathrm{L})$ were identified at eight sites in five basins. When significant trends and non-significant changes in lead concentrations are considered, 56 percent of sites showed a decrease.

Zinc concentrations showed significant trends at 21 sites (figs. 8 and 1-8). ${ }^{10}$ Upward trends of 0.1 to 423 percent $(0.01$ to $17.2 \mu \mathrm{g} / \mathrm{L})$ were identified at 11 sites in 5 basins. Some of the largest increases in zinc-130.1 to 423.0 percent $(11.1$ to $17.2 \mu \mathrm{g} / \mathrm{L})$ - were noted at three sites in the Kankakee River Basin. Zinc increased at five sites in the Upper Wabash River Basin. Downward trends of -12.9 to -48.9 percent $(-1.0$ to $-25.5 \mathrm{mg} / \mathrm{L})$ were identified at 10 sites in 5 basins. When significant trends and non-significant changes in zinc concentrations are considered, 53 percent of sites showed a decrease.

\footnotetext{
${ }^{9}$ The statistical trends technique used in this analysis is typically applied to data with less than approximately 10 percent censored values (Vecchia, 2003); 57.9 percent of lead values were censored.

${ }^{10}$ The statistical trends technique used in this analysis is typically applied to data with less than approximately 10 percent censored values (Vecchia, 2003); 34.6 percent of zinc values were censored.
} 


\section{A. Nitrate}

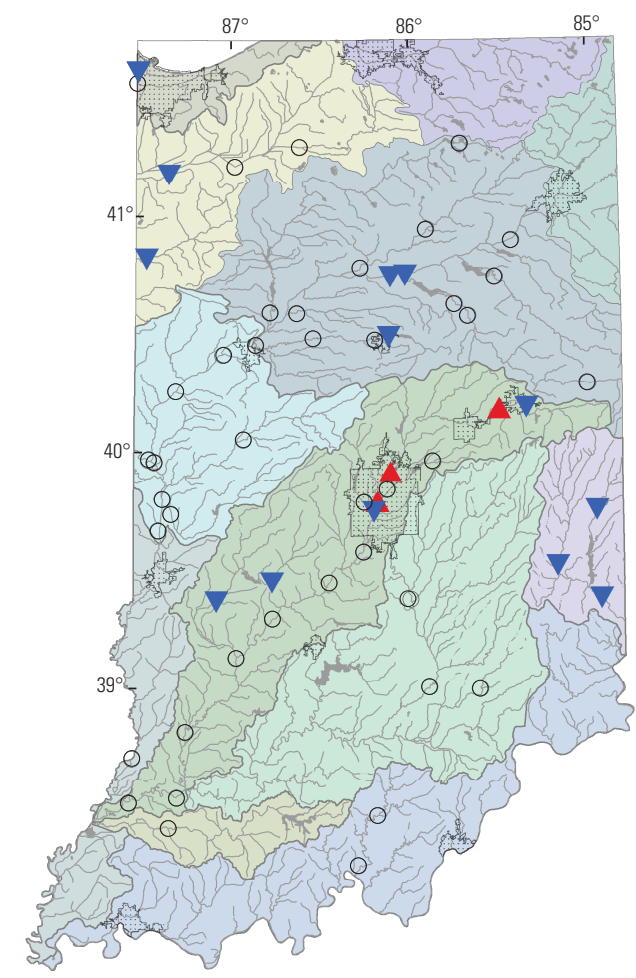

\section{Phosphorus}

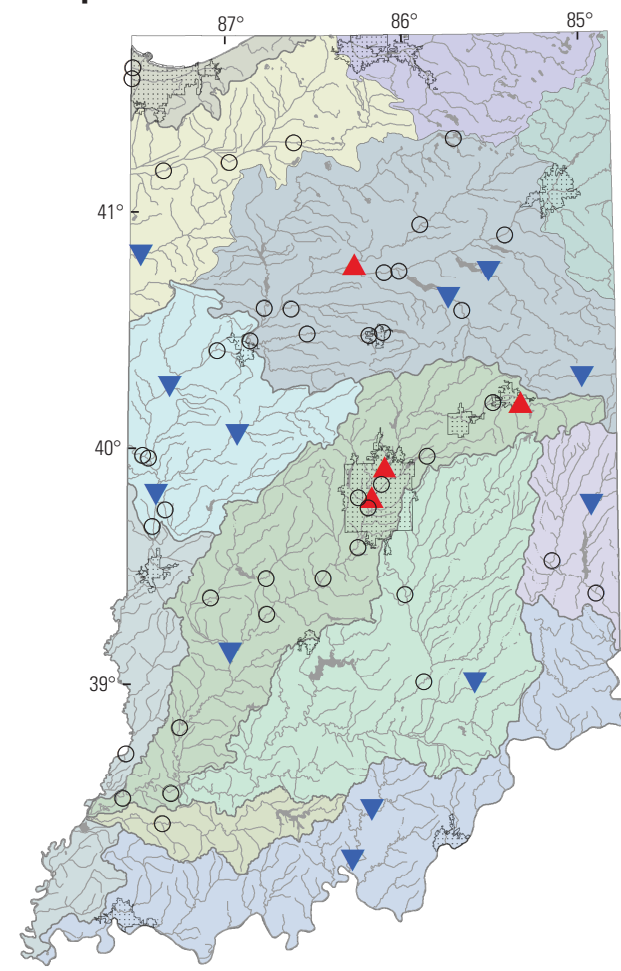

\section{B. Organic nitrogen}

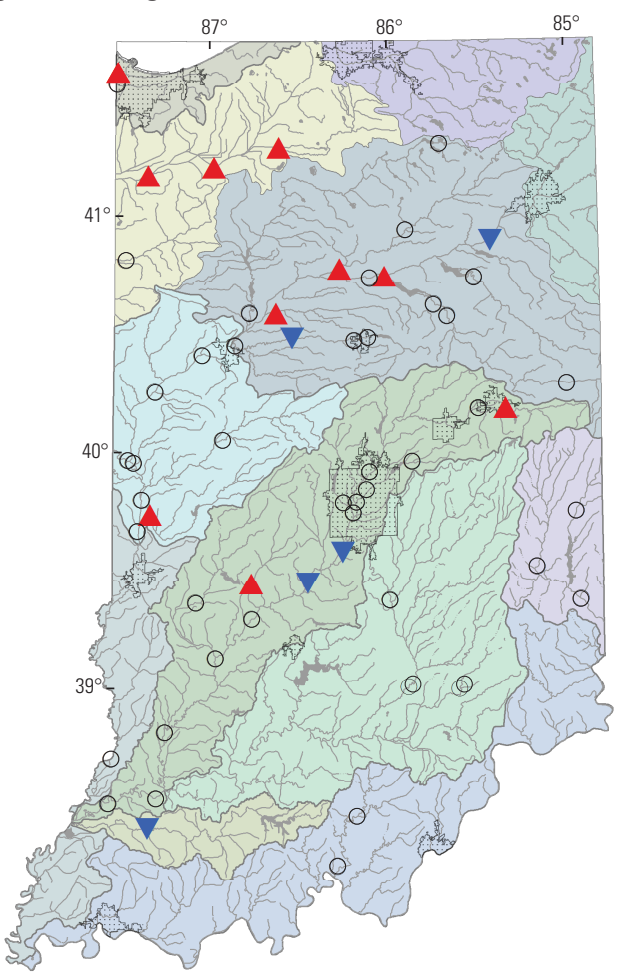

\section{Suspended solids}

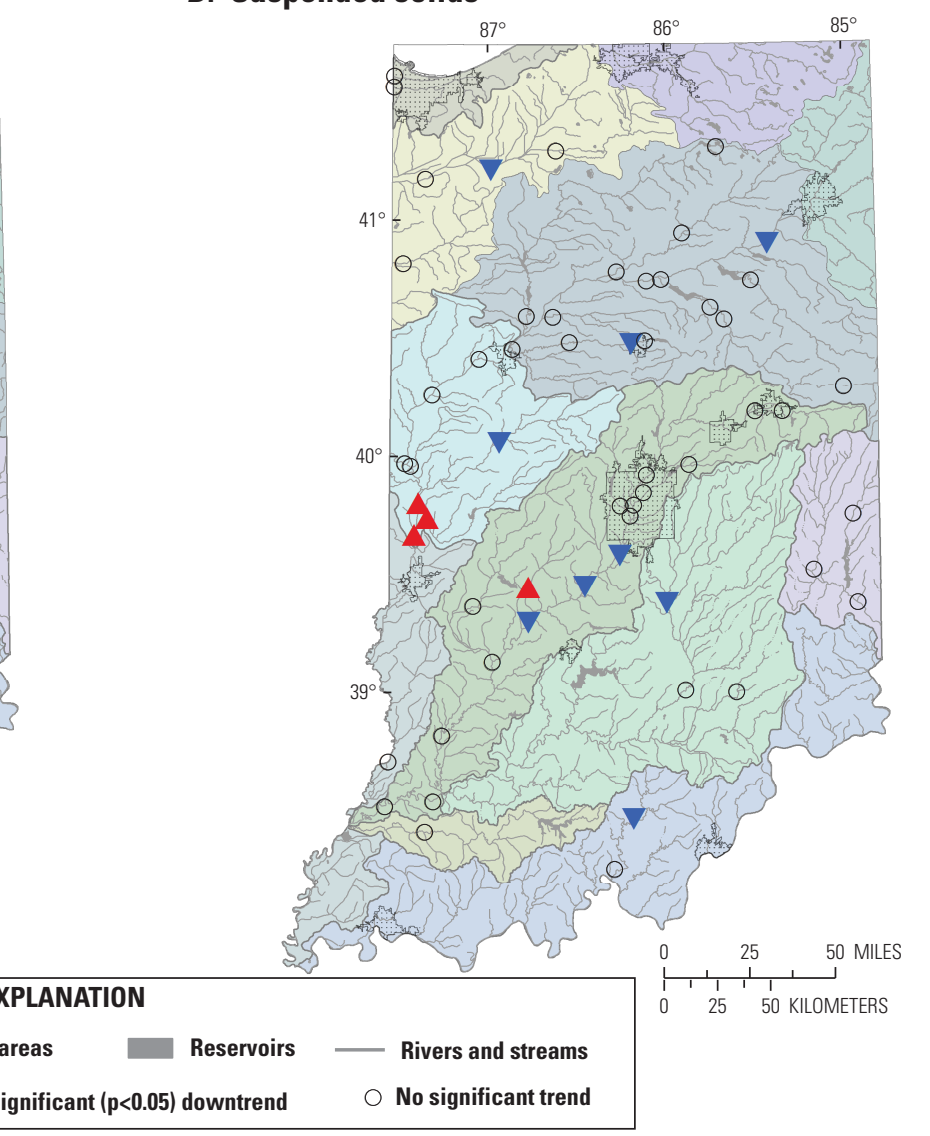

Figure 7. Sites with significant trends in concentrations of nutrients and suspended solids, 2000-10. A, Nitrate. B, Organic nitrogen. $C$, Phosphorus. D, Suspended solids. 


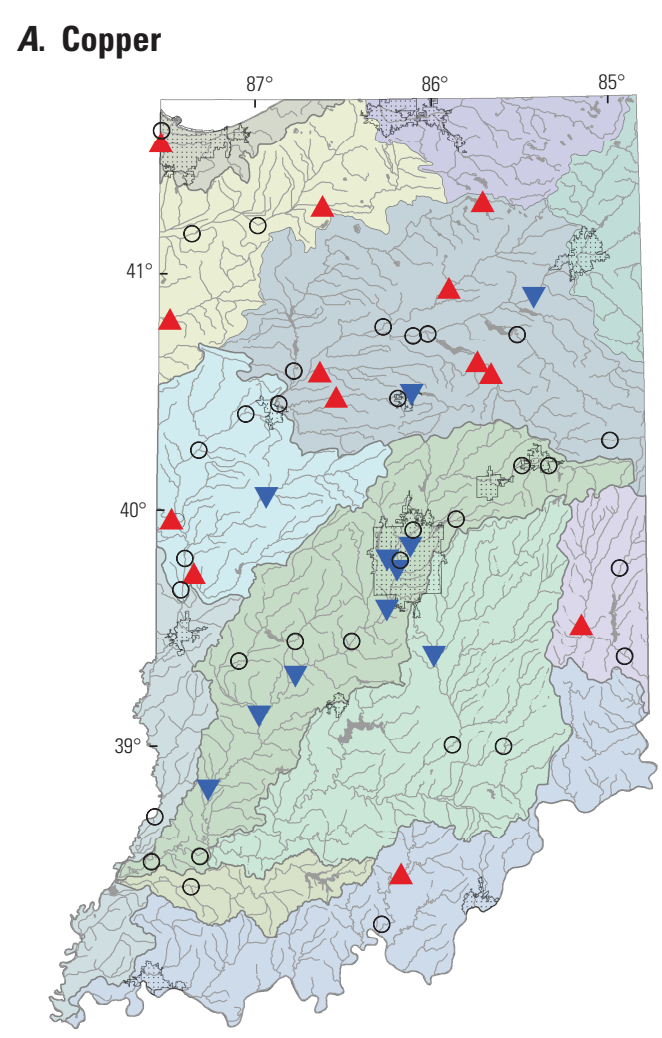

\section{B. Iron}

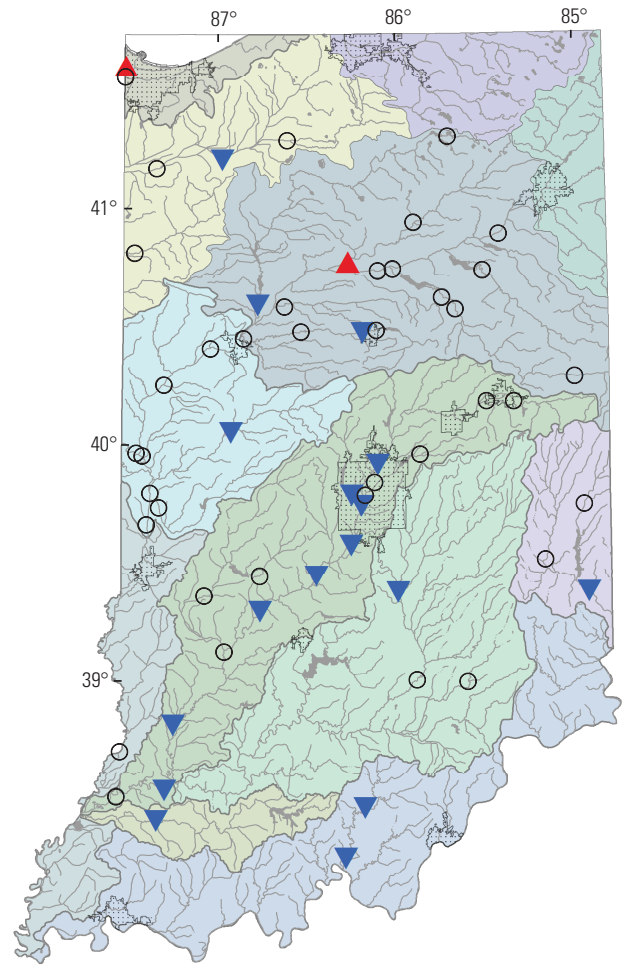

C. Lead

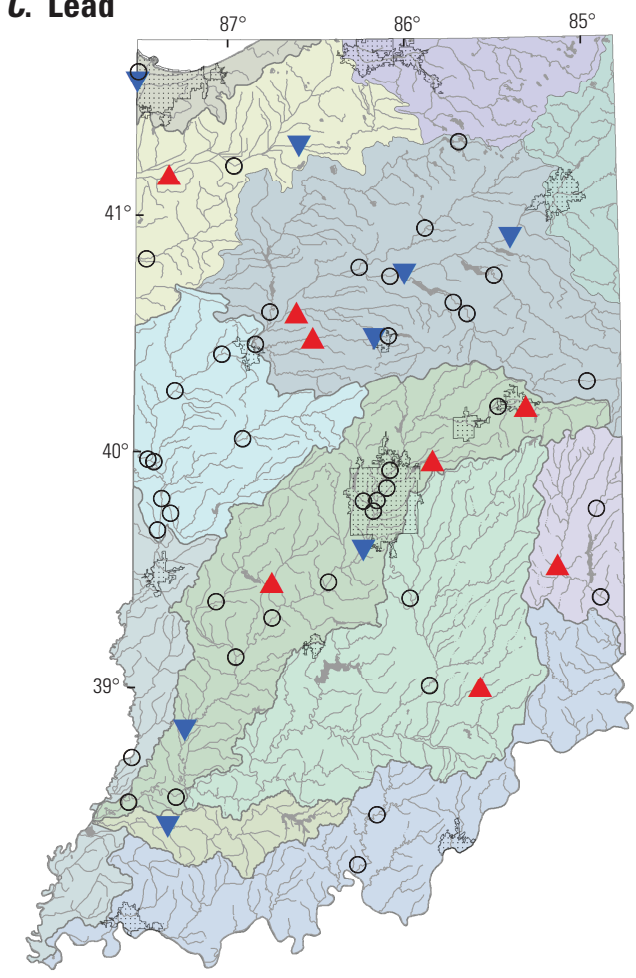

D. Zinc
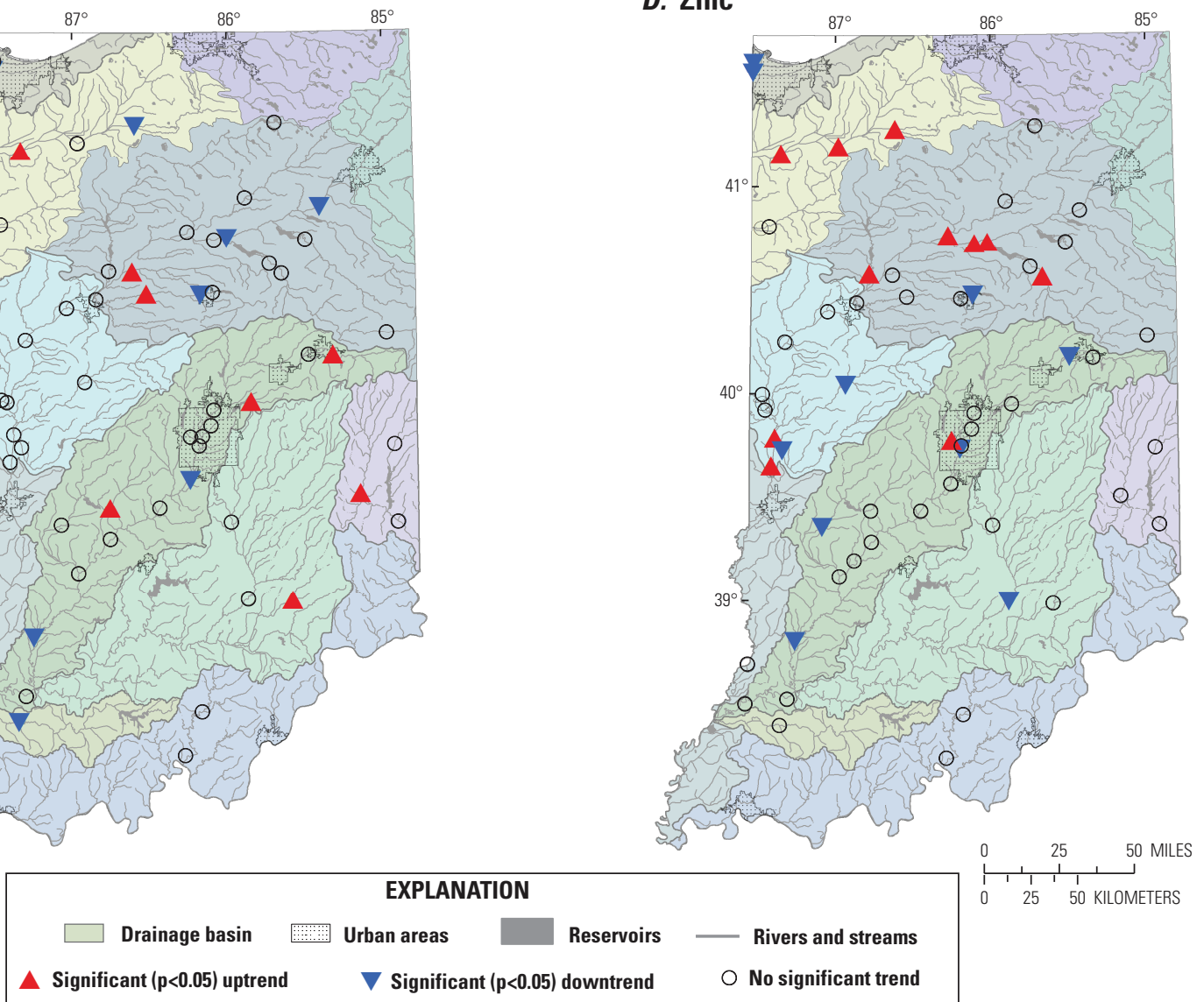

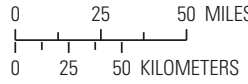

Figure 8. Sites with significant trends in concentrations of metals, 2000-10. $A$, Copper. $B$, Iron. $C$, Lead. $D$, Zinc. 


\section{Ions and Dissolved Solids}

Chloride concentrations showed significant trends at 30 sites (figs. 9 and 1-9). Upward trends of 5.8 to 23.6 percent $(1.3$ to $11.2 \mathrm{mg} / \mathrm{L})$ were identified at nine sites in four basins. Increases in chloride were noted at three sites in the Indianapolis area of the West Fork White River Basin. Downward trends were identified at 21 sites in 6 basins, ranging from -8.0 to -46.8 percent. The two largest decreases were -102.5 and $-57.4 \mathrm{mg} / \mathrm{L}$ in the Lake Michigan Basin. Decreases in chloride were noted at eight sites in the Upper Wabash River Basin. When significant trends and non-significant changes in chloride concentrations are considered, 67 percent of sites showed a decrease.

Sulfate concentrations showed significant trends at 32 sites (figs. 9 and 1-10). Upward trends of 4.7 to 10.1 percent $(1.4$ to $8.9 \mathrm{mg} / \mathrm{L})$ were identified at two sites in the Kankakee River Basin and one site in the Upper Wabash River Basin. Downward trends were identified at 29 sites in 6 basins, ranging from -6.3 to -57.1 percent. The largest decreases were $-121.2 \mathrm{mg} / \mathrm{L}$ at one site in the Lake Michigan Basin and $-31.2 \mathrm{mg} / \mathrm{L}$ at one site in the West Fork White River Basin. Decreases in sulfate were noted at 12 sites in the Upper Wabash River Basin. When significant trends and non-significant changes in sulfate concentrations are considered, 82 percent of sites showed a decrease.

Hardness concentrations showed significant trends at 22 sites (figs. 9 and 1-11). Upward trends of 5.7 to 18.8 percent ( 15.4 to $53.5 \mathrm{mg} / \mathrm{L}$ ) were identified at 13 sites in 5 basins. Increases in hardness were noted at a group of four sites each in the Kankakee River and Middle Wabash River Basins. Downward trends of -5.2 to -16.0 percent $(-17.5$ to $-38.2 \mathrm{mg} / \mathrm{L})$ were identified at nine sites in three basins. Decreases in hardness were noted at four sites each in the West Fork White River and Upper Wabash River Basins. When significant trends and non-significant changes in hardness concentrations are considered, 53 percent of sites showed an increase.

Dissolved solids concentrations showed significant trends at 26 sites (figs. 9 and 1-12). Upward trends of 6.0 to 11.8 percent $(20.9$ to $43.5 \mathrm{mg} / \mathrm{L})$ were identified at two sites in the Middle Wabash River Basin and at one site in the Kankakee River Basin. Downward trends were identified at 23 sites in 7 basins, ranging from -3.8 to -36.0 percent $(-10.9$ to $-330.5 \mathrm{mg} / \mathrm{L})$. The two largest decreases were noted at two sites in the Lake Michigan Basin. When significant trends and non-significant changes in dissolved solids concentrations are considered, 79 percent of sites showed a decrease.

\section{Limitations and Considerations}

This report describes water quality in Indiana based on concentration summaries and trend analysis of data from 57 FSMP sites representing 11 years. Therefore, this description of water quality in Indiana was limited by the geographic representativeness of the sites, parameters selected for the analysis, the time period of the analysis, and the FSMP network design. These limitations and potential consideration are described in the following discussion.

The Indiana FSMP provides a statewide set of sites on large streams with a generally consistent set of water-quality constituents analyzed in monthly water samples for multiple years, but all of the FSMP sites in Indiana were not included in this study for several reasons. The full network of 163 FSMP sites varies in completeness of annual water-quality records and the number of consecutive years with complete annual records. The network also varies in the number of constituents that were consistently analyzed each month and each year. Many of the sites in the network are not associated with a streamgage having a complete annual streamflow record, which is necessary for a flow-adjusted concentration trends analysis.

The FSMP sites are not a network designed to represent the major streams, drainage basins, and watersheds in Indiana. Rather, sites are mostly located downstream from areas with one or more permitted discharges of wastewater effluent, and sometimes they are paired with a FSMP site upstream of the discharges. Samples at FSMP sites may vary in their representativeness of stream-water quality because they were grab samples from the center of flow analyzed for total recoverable, not dissolved plus particulate fractions of a constituent. Grab samples generally are most representative when streams are well mixed across their width and depth. Depending upon streamflow conditions or the sample location, some constituents may not be uniformly distributed across the width and depth of a stream. Data for evaluating the representativeness of the water samples were not available for this study.

For purposes of this study, some FSMP sites were not included and the resulting geographic coverage was uneven across Indiana. The Maumee River and St. Joseph River Basins do not have sites represented in this study. The Lake Michigan, Ohio River, Patoka River, and Lower Wabash River Basins had 1 or 2 sites, compared with the Upper Wabash River and West Fork White River Basins that had 16 and 17 sites, respectively.

The summary statistics and 11-year trends in concentrations of 12 constituents presented in this report are tied to the scope of this initial study, but a number of other considerations are possible. (1) The study has established a data compilation and analysis process that can be applied for selected constituents for longer time periods at some sites. Longer time periods may show more than one trend at a site, with different directions and magnitude, unlike the single 11-year trends identified at sites in this study. (2) Constituent loads, the product of concentration and streamflow, were beyond the scope of this study, although data were compiled to make the calculation and analysis of loads possible. (3) Water-quality data for other Indiana streams and other constituents not included in this study are available from IDEM, USGS, and other sources, but a compilation and analysis of these other data were beyond the scope of this study. (4) Interpretation of the reasons and contributing factors for the trends in constituent concentrations 


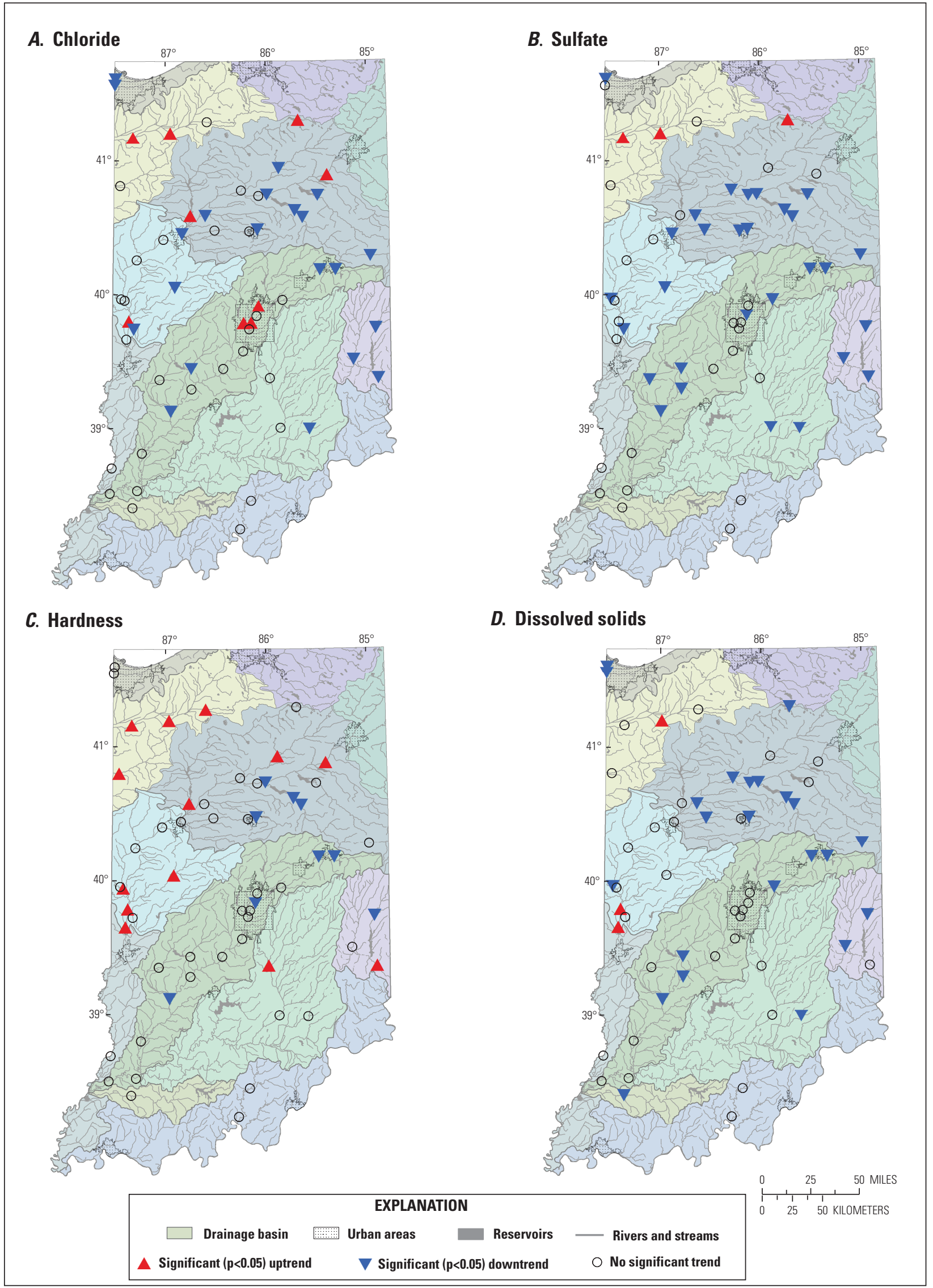

Figure 9. Sites with significant trends in concentrations of ions and dissolved solids, 2000-10. $A$, Chloride. $B$, Sulfate. $C$, Hardness. $D$, Dissolved solids. 
and differences and similarities in constituent concentrations among drainage basins was beyond the scope of this study. Ancillary data that could be used to understand why and where constituent trends and differences were observed include information about permitted discharges of treated effluent and stormwater, nutrient application, atmospheric deposition, and land cover.

\section{Regional Comparisons}

Water quality in Indiana can be compared with findings from other regional studies during a similar time period. The following discussion provides a broader geographic context for some of the results of this study. Murphy and others (2013) reported a downward trend in nitrate concentrations for the Ohio River Basin (although the change in annual concentrations was small) and increasing nitrate concentrations in much of the Mississippi River and its tributaries for 2000-10. Similarly, nitrate generally declined in much of Indiana during this same period, which appears consistent with the results from this larger scale study. Lorenz and others (2008) reported trends in flow-adjusted concentrations in the Mississippi River Basin for 1975-2004, including a stream site in central Indiana. For this site, they found significant upward trends in nitrate and organic nitrogen, a non-significant increase in phosphorus, and a non-significant decrease in total nitrogen and total suspended sediment (similar to suspended solids). Sprague and others (2009) looked at trends in nutrients in major rivers of the U.S. for 1993-2003, including a stream site in central Indiana. For this site, they reported a significant downward trend in flow-adjusted nitrate concentrations and no significant change in phosphorus or total nitrogen concentrations.

\section{Summary and Conclusions}

Water-quality data from the Indiana Department of Environmental Management Fixed Station Monitoring Program (FSMP) were combined with streamflow data from collocated or nearby U.S. Geological Survey (USGS) streamgages. The final dataset for this study consisted of 86,110 concentration values for 12 constituents in 7,345 water samples from 57 FSMP sites for 11 years (January 1, 2000-December 31, 2010). The 12 constituents are the nutrients nitrate, organic nitrogen, and phosphorus; suspended solids; the metals copper, iron, lead, and zinc; the ions chloride and sulfate together with hardness as a measure of the calcium carbonate ion; and dissolved solids.

The parametric time-series model, QWTREND, was used to develop streamflow-adjusted constituent concentrations, to adjust for seasonal variance and serial correlation, and to identify trends independent of streamflow-related variability. A total of 684 trend analyses were made and 250 statistically significant trends were identified - 167 downward trends and
83 upward trends. An additional 434 non-significant changes in constituent concentrations were noted for the study period. The number of significant trends compared with the total number of trend analyses per major drainage basin showed that the Kankakee River Basin had the most significant upward trends (37.5 percent). The most significant downward trends were in the Whitewater River Basin ( -38.9 percent), the Lake Michigan Basin ( -37.5 percent), and the Patoka River Basin $(-33.3$ percent $)$.

Nutrient concentrations in this study generally were too high relative to standards and criteria. Although nitrate exceeded the Indiana water-quality standard in 1.2 percent of samples, the national recommended criteria for total nitrogen in the three ecoregions in Indiana were exceeded by more than one-half of the nitrate analyses in the study. Most of the phosphorus analyses in the study also exceeded the national recommended criteria for the three ecoregions in Indiana.

Copper, lead, zinc, chloride, sulfate, and dissolved solids concentrations were in acceptable ranges relative to standards and criteria in more than 97 percent of samples. Copper and lead exceeded the upper range of Indiana water-quality standards for this dataset in 0.2 and 2.3 percent of samples, respectively. Zinc exceeded the Indiana water-quality standard in 0.3 percent of samples and the top 4 percent of zinc concentrations exceeded the national recommended criteria. The Indiana water-quality standard for a public-water system intake was exceeded by chloride in 0.3 percent of samples, by sulfate in 0.9 percent of samples, and by dissolved solids in 2.9 percent of samples.

The two Lake Michigan Basin sites had the highest concentrations and were in a unique statistical group for 10 of the 12 constituents, with concentrations many times higher than the statewide median and higher than the medians of most other basins. The two Ohio River Basin sites had the lowest concentrations and were in a unique statistical group for 6 of the 12 constituents.

Nitrate concentrations showed significant trends at 16 sites - upward trends at 3 sites in the West Fork White River Basin upstream from and inside the Indianapolis area, Indiana, and downward trends at 13 sites in 5 basins in the northern half of Indiana. Organic nitrogen concentrations showed significant trends at 15 sites - upward trends at 10 sites in 5 basins and downward trends at 5 sites in 4 basins. Phosphorus concentrations showed significant trends at 16 sites - upward trends including 4 sites in the West Fork White River Basin upstream from and in the Indianapolis area and downward trends at 12 sites in 7 basins. Suspended solids concentrations showed significant trends at 13 sites - upward trends at 4 sites in 2 basins and downward trends at 9 sites in 6 basins.

Copper concentrations showed significant trends at 24 sites - upward trends at 13 sites in 6 basins and downward at 11 sites in 4 basins. Copper decreased at seven sites in the West Fork White River Basin; the two largest increases were in the Lake Michigan Basin. Iron concentrations showed significant trends at 19 sites - upward trends at 2 sites in 2 basins 
and downward trends 17 sites in 8 basins. Iron decreased at seven sites in the West Fork White River Basin. Lead concentrations showed significant trends at 17 sites - upward trends at 9 sites in 5 basins and downward trends at 8 sites in 5 basins. Significant increases in lead generally were small, and significant decreases generally were large. Zinc concentrations showed significant trends at 21 sites - upward trends at 11 sites in 5 basins and downward trends at 10 sites in 5 basins. Some of the largest increases in zinc were noted at three sites in the Kankakee River Basin; zinc increased at five sites in the Upper Wabash River Basin.

Chloride concentrations showed significant trends at 30 sites - upward trends at 9 sites in 4 basins and downward trends at 21 sites in 6 basins. Increases in chloride were noted at three sites upstream from and in the Indianapolis area of the West Fork White River Basin. The two largest decreases in chloride were at two sites in the Lake Michigan Basin. Decreases in chloride were noted at eight sites in the Upper Wabash River Basin. Sulfate concentrations showed significant trends at 32 sites - upward trends at 3 sites in 2 basins and downward trends at 29 sites in 6 basins. Decreases in sulfate were noted at 12 sites in the Upper Wabash River Basin. Hardness concentrations showed significant trends at 22 sites - upward trends at 13 sites in 5 basins and downward trends at 9 sites in 3 basins. Increases in hardness were noted at a group of four sites each in the Kankakee River and Middle Wabash River Basins. Decreases in hardness were noted at four sites each in the West Fork White River and Upper Wabash River Basins. Dissolved solids concentrations showed significant trends at 26 sites - upward trends at 3 sites in 2 basins and downward trends at 23 sites in 7 basins. The two largest decreases in dissolved solids were noted at two sites in the Lake Michigan Basin.

The interpretations of trends in water quality in Indiana streams described in this report were limited by the waterquality monitoring sites and samples that were analyzed. All 163 FSMP sites in Indiana were not included in this study because they were not near a USGS streamgage or they had incomplete data records. The geographic coverage of sites in this study was uneven among the major drainage basins in Indiana. The Maumee River and St. Joseph River Basins were not represented by sites. The objectives of this study limited the number of constituents and the number of years for which trends were analyzed.

In conclusion, the analysis of trends in streamflowadjusted constituent concentrations at the FSMP sites in this study indicated a greater number of downward trends, signaling a potential pattern of improving statewide water quality. Two streams in the Lake Michigan Basin have shown substantial decreases in most constituents. The West Fork White River near Indianapolis showed increases in nitrate and phosphorus; the Kankakee River showed increases in copper, zinc, chloride, sulfate, and hardness. This initial study provides a basis for future investigations of the FSMP and streamflow data for Indiana.

\section{Acknowledgments}

The authors gratefully acknowledge the contributions of two USGS colleagues. Wes Stone provided computer programs used for data analysis and summary in this project, and Wes Stone and Steve Sando provided technical peer reviews of the draft report. The insights and suggestions of these two peer reviewers improved the final report and were most appreciated.

\section{References Cited}

Clark, G.D., and Larrison, Dorothy, eds., 1980, The Indiana water resource-Availability, uses, and needs: Indianapolis, Ind., Indiana Department of Natural Resources, 508 p.

ESRI, 2007, ArcGIS 9.2 Desktop Help, accessed August 1, 2014, at http://webhelp.esri.com/arcgisdesktop/9.2/index. cfm? TopicName $=$ welcome.

Galloway, J.M., Vecchia, A.V., Vining, K.C., Densmore, B.K., and Lundgren, R.F., 2012, Evaluation of water-quality characteristics and sampling design for streams in North Dakota, 1970-2008: U.S. Geological Survey Scientific Investigations Report 2012-5216, 303 p., accessed August 1, 2014, at $h t t p: / / p u b s . u s g s . g o v / s i r / 2012 / 5216 /$.

Gray, J.R., Glysson, G.D., Turcios, L.M., and Schwarz, G.E., 2000, Comparability of suspended-sediment concentration and total suspended solids data: U.S. Geological Survey Water-Resources Investigations Report 00-4191, 14 p., accessed August 1, 2014, at http://water.usgs.gov/osw/pubs/ WRIR00-4191.pdf.

Helsel, D.R., 2004, Nondetects and data analysis-Statistics for censored environmental data: Hoboken, N.J., Wiley-Interscience, $268 \mathrm{p}$.

Helsel, D.R., and Hirsch, R.M., 2002, Statistical methods in water resources: U.S. Geological Survey Techniques of Water Resources Investigations, book 4, chap. A3, 522 p., accessed August 1, 2014, at http://pubs.usgs.gov/ twri/twri4a3/.

Hem, J.D., 1985, Study and interpretation of the chemical characteristics of natural water ( $3 \mathrm{~d}$ ed.): U.S. Geological Survey Water Supply Paper 2254, 264 p., 3 pls., accessed August 1, 2014, at http://pubs.usgs.gov/wsp/wsp2254/html/ pdf.html.

Indiana Administrative Code, 2013, Title 327, Article 2, Water quality standards, accessed August 1, 2014, at http://www.in.gov/legislative/iac/T03270/A00020.PDF. 
Indiana Department of Environmental Management, 2006, Fixed Station (Ambient) Monitoring Program, Fact Sheet A-012-OWQ-A-SU-06-0-R5, accessed August 1, 2014, at http://www.in.gov/idem/files/wqsurvey_012fixstat(ambt) monprog.pdf.

Indiana Department of Environmental Management, 2013, Indiana water quality atlas, accessed August 1, 2014, at http://www.in.gov/idem/nps/pages/iwqa/index.html.

Indiana Department of Environmental Management, 2014, Indiana integrated water monitoring and assessment report to the U.S. EPA, accessed August 1, 2014, at http://www. in.gov/idem/nps/files/ir_2014_report.pdf.

Indiana State Climate Office, 2013, About Indiana climate, accessed August 1, 2014, at https://climate.agry.purdue.edu/ climate/narrative.asp.

Indiana Water Monitoring Council, 2013, Indiana water monitoring inventory, accessed August 1, 2014, at http://inwater. agriculture.purdue.edu/monitoring/.

Jian, Xiaodong, Wolock, D.M., Lins, H.F., and Brady, Steve, 2012, Streamflow of 2011-Water year summary: U.S. Geological Survey Fact Sheet 2012-3085, 8 p., accessed August 1, 2014, at http://pubs.usgs.gov/fs/2012/3085.

Lorenz, D.L., Robertson, D.M., Hall, D.W., and Saad, D.A., 2008, Trends in streamflow and nutrient and suspendedsediment concentrations and loads in the Upper Mississippi, Ohio, Red, and Great Lakes River Basins, 1975-2004: U.S. Geological Survey Scientific Investigations Report 2008-5213, 81 p. [Also available at http://pubs.usgs.gov/ $\operatorname{sir} / 2008 / 5213 /$.

Murphy, J.C., Hirsch, R.M., and Sprague, L.A., 2013, Nitrate in the Mississippi River and its tributaries, 1980-2010-An update: U.S. Geological Survey Scientific Investigations Report 2013-5169, 31 p., accessed August 1, 2014, at http://pubs.usgs.gov/sir/2013/5169/.

Ryberg, K.R., and Vecchia, A.V., 2012, waterData-An R package for retrieval, analysis, and anomaly calculation of daily hydrologic time series data, version 1.0: U.S. Geological Survey Open-File Report 2012-1168, 8 p., accessed August 1, 2014, at http://pubs.usgs.gov/of/2012/1168/.

Seaber, P.R., Kapinos, F.P., and Knapp, G.L., 1987, Hydrologic unit maps: U.S. Geological Survey Water-Supply Paper 2294, 63 p. [Also available at http://pubs.usgs.gov/ wsp/wsp2294/pdf/wsp_2294_a.pdf.]

Simley, J.D., and Carswell, W.J., Jr., 2009, The National Map_Hydrography: U.S. Geological Survey Fact Sheet 2009-3054, 4 p., accessed August 1, 2014, at http://pubs. usgs.gov/fs/2009/3054/.
Sprague, L.A., Mueller, D.K., Schwarz, G.E., and Lorenz, D.L., 2009, Nutrient trends in streams and rivers of the United States, 1993-2003: U.S. Geological Survey Scientific Investigations Report 2008-5202, 196 p. [Also available at http://pubs.usgs.gov/sir/2008/5202.]

U.S. Environmental Protection Agency, 2000a, Ambient water quality criteria recommendations-Information supporting the development of State and Tribal nutrient criteria-Rivers and streams in nutrient ecoregion VI: Office of Water, EPA 822-B-00-017, 91 p.

U.S. Environmental Protection Agency, 2000b, Ambient water quality criteria recommendations-Information supporting the development of State and Tribal nutrient criteria-Rivers and streams in nutrient ecoregion VII: Office of Water, EPA 822-B-00-018, 93 p.

U.S. Environmental Protection Agency, 2000c, Ambient water quality criteria recommendations-Information supporting the development of State and Tribal nutrient criteria-Rivers and streams in nutrient ecoregion IX: Office of Water, EPA 822-B-00-019, 108 p.

U.S. Environmental Protection Agency, 2009, National recommended water quality criteria, accessed August 1, 2014, at http://water.epa.gov/scitech/swguidance/standards/criteria/ current/index.cfm.

U.S. Geological Survey, 2013a, National Water Information System-USGS water data for the Nation, accessed August 1, 2014, at http://waterdata.usgs.gov/nwis.

U.S. Geological Survey, 2013b, National Streamflow Information Program, accessed August 1, 2014, at http://water.usgs. gov/nsip/.

U.S. Geological Survey, 2013c, The USGS Water Science School-Phosphorus and water, accessed August 1, 2014, at http://ga.water.usgs.gov/edu/phosphorus.html.

U.S. Geological Survey, 2014a, The National Map-Hydrography, accessed August 1, 2014, at http://nhd.usgs.gov/.

U.S. Geological Survey, 2014b, National Water-Quality Assessment Program-Nutrients National Synthesis Project, accessed August 1, 2014, at http://water.usgs.gov/ nawqa/nutrients/datasets/retrodesc.html.

Vecchia, A.V., 2000, Water-quality trend analysis and sampling design for the Souris River, Saskatchewan, North Dakota, and Manitoba: U.S. Geological Survey WaterResources Investigations Report 00-4019, 77 p. [Also available at http://nd.water.usgs.gov/pubs/wri/wri004019/.] 
Vecchia, A.V., 2003, Water-quality trend analysis and sampling design for streams in North Dakota, 1971-2000: U.S. Geological Survey Water-Resources Investigations Report 03-4094, 73 p. [Also available at http://nd.water.usgs.gov/ pubs/wri/wri034094/.]

Vecchia, A.V., 2004a, Using time series analysis to analyze trends in concentration, in National Monitoring Conference, Chattanooga, Tenn., May 17-20, 2004: 19 p.
Vecchia, A.V., 2004b, Statistical techniques for trend and load estimation, in National Monitoring Conference, Chattanooga, Tenn., May 17-20, 2004: 74 p.

Vecchia, A.V., 2005, Water-quality trend analysis and sampling design for streams in the Red River of the North Basin, Minnesota, North Dakota, and South Dakota, 1970-2001: U.S. Geological Survey Scientific Investigations Report 2005-5224, 54 p. [Also available at http://pubs.usgs.gov/sir/2005/5224/.] 



\section{Appendix 1. Significant and non-significant trends for 12 constituents at 57 stream sites in Indiana, 2000-10}


$\boldsymbol{A}$

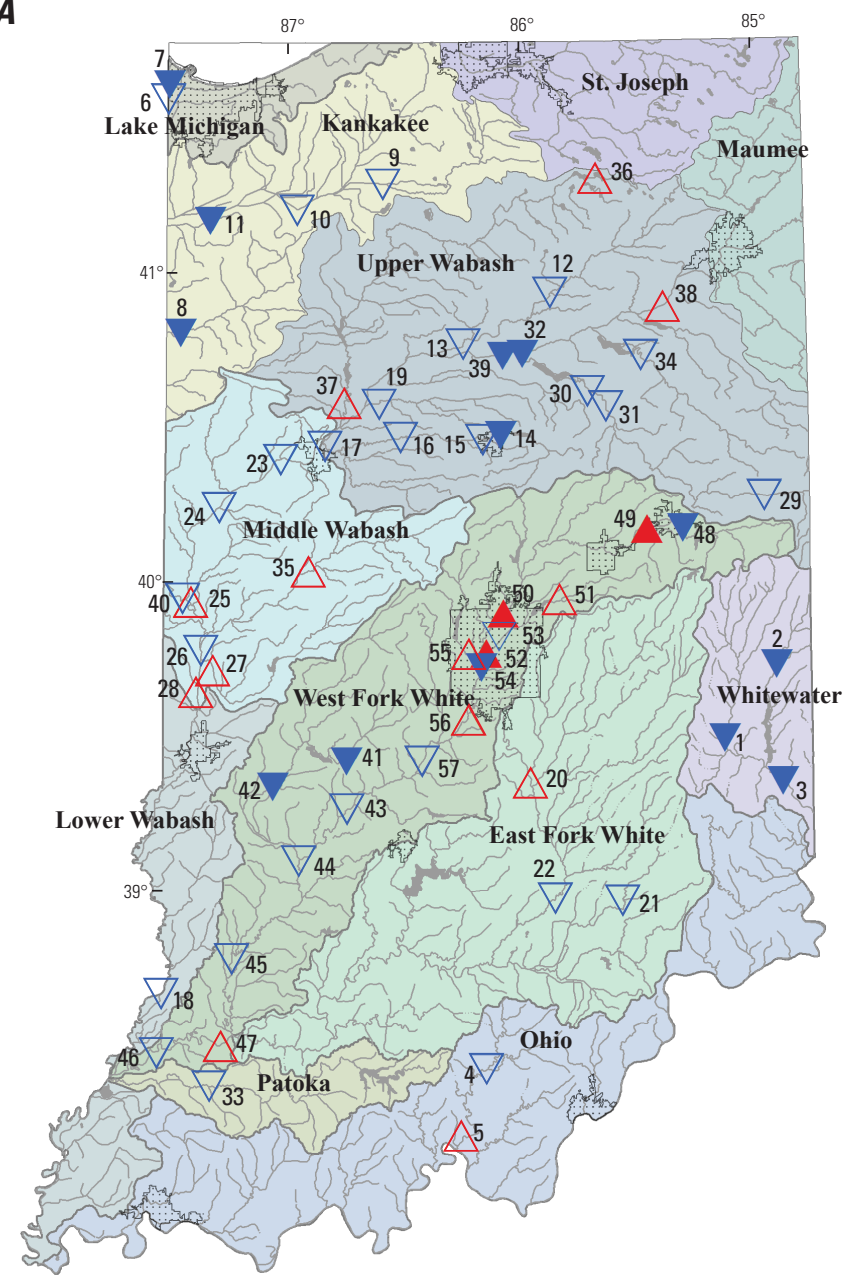

B

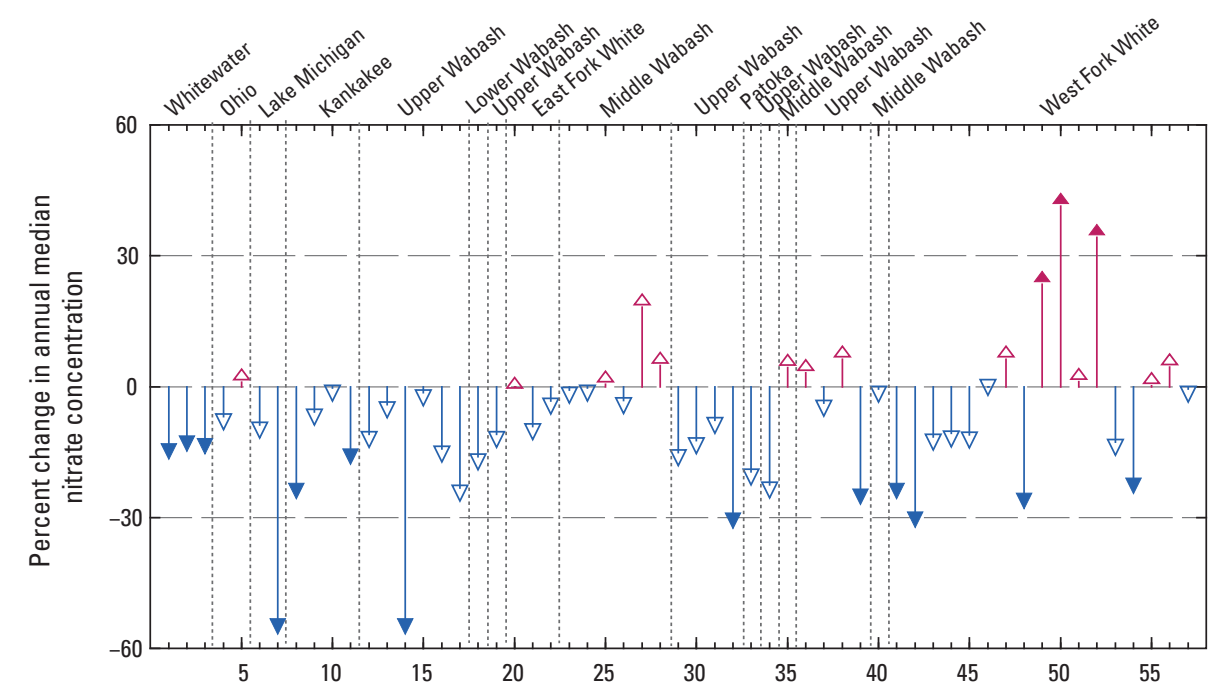

C

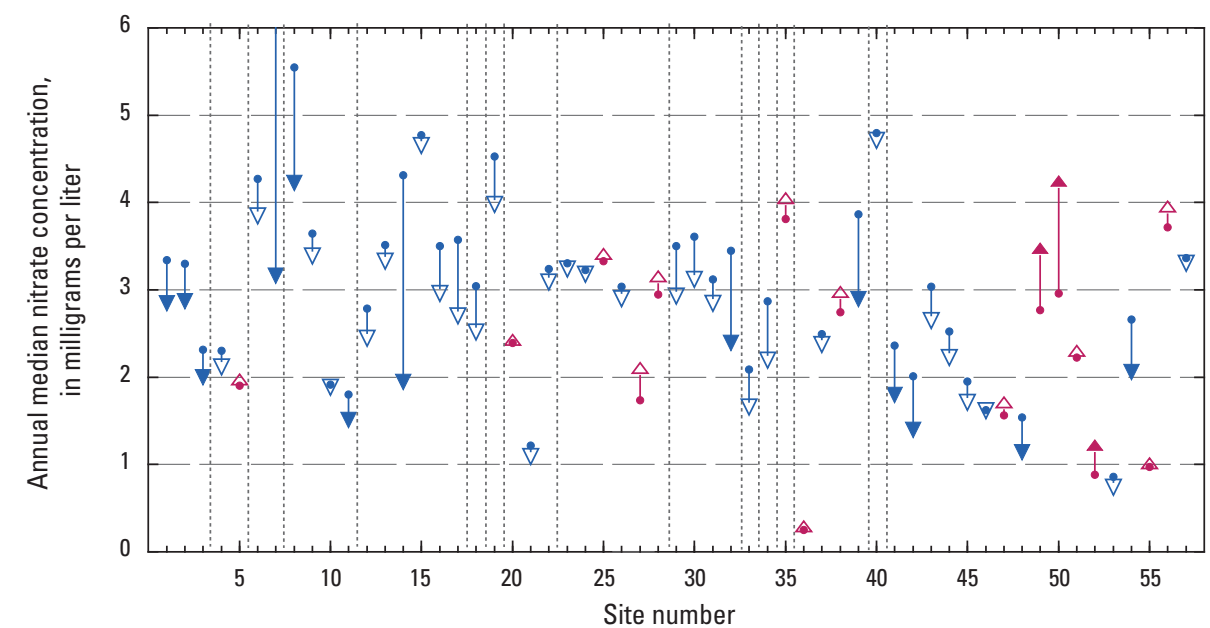

EXPLANATION

Figure 1-1. Significant and non-significant trends in nitrate at 57 stream sites in Indiana, 2000-10. 
$\boldsymbol{A}$

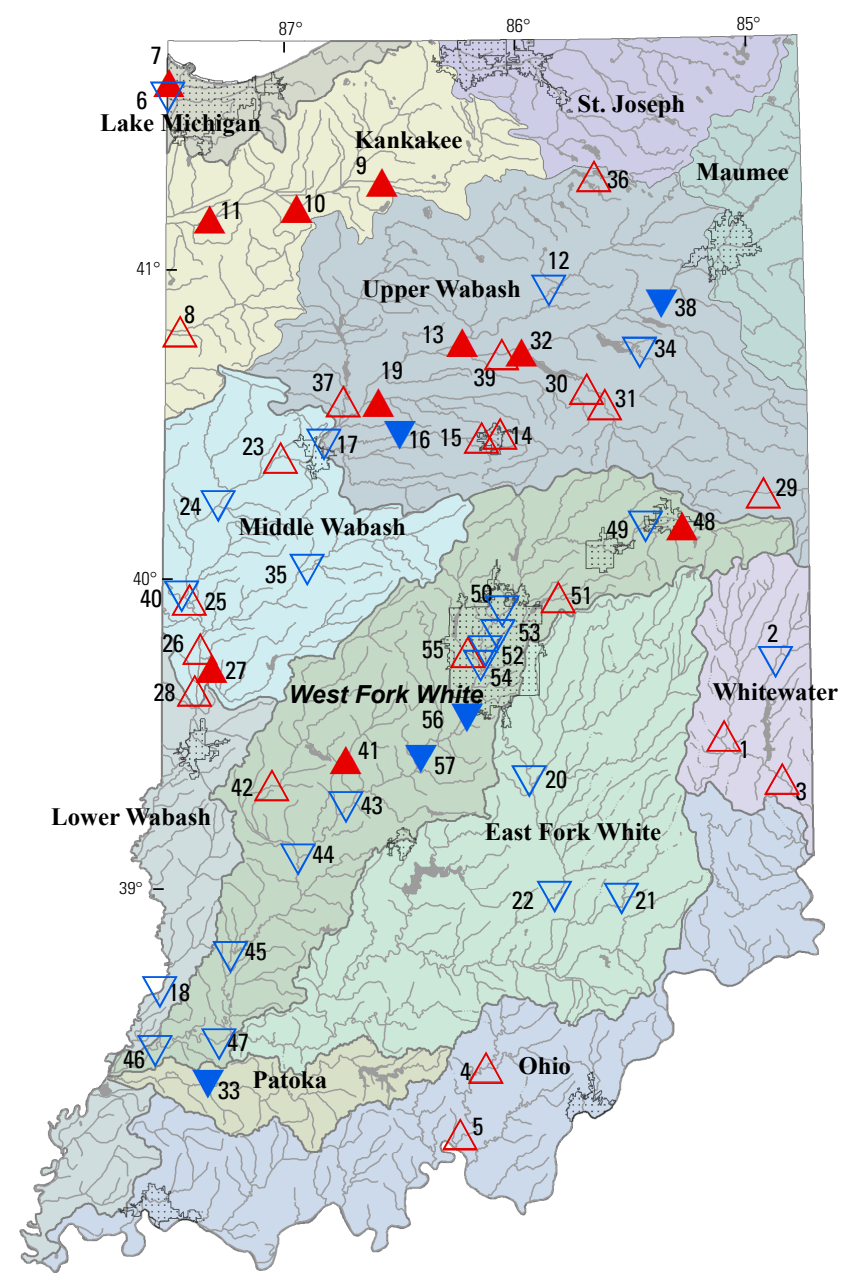

B

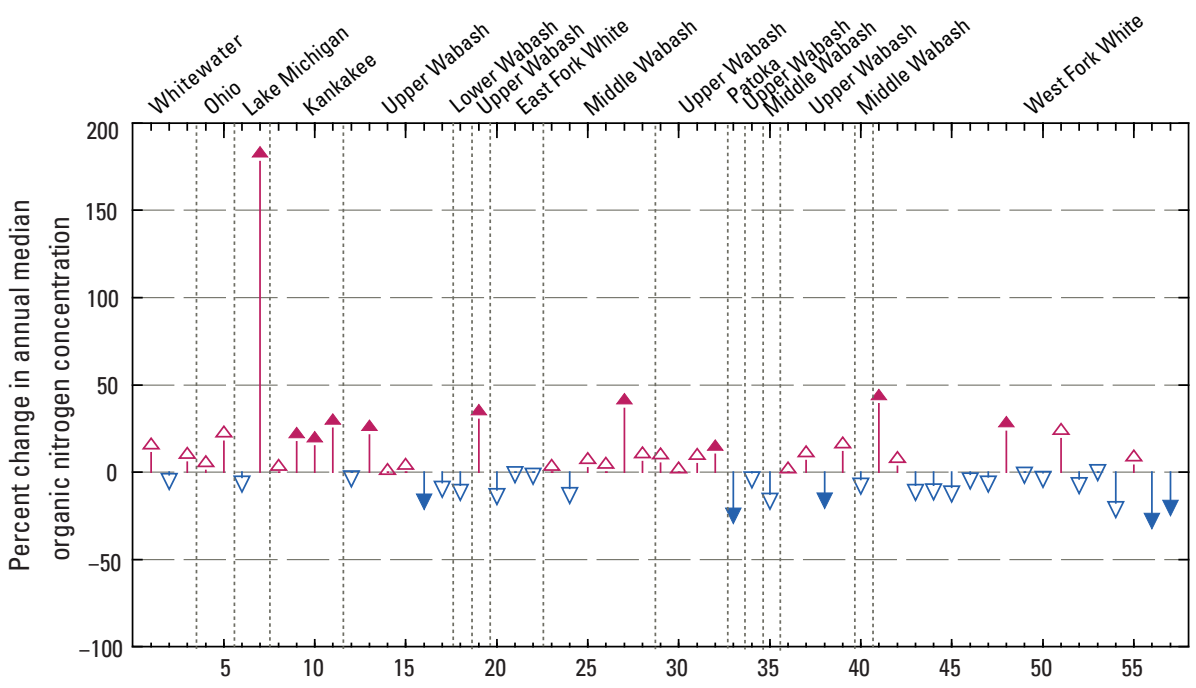

C

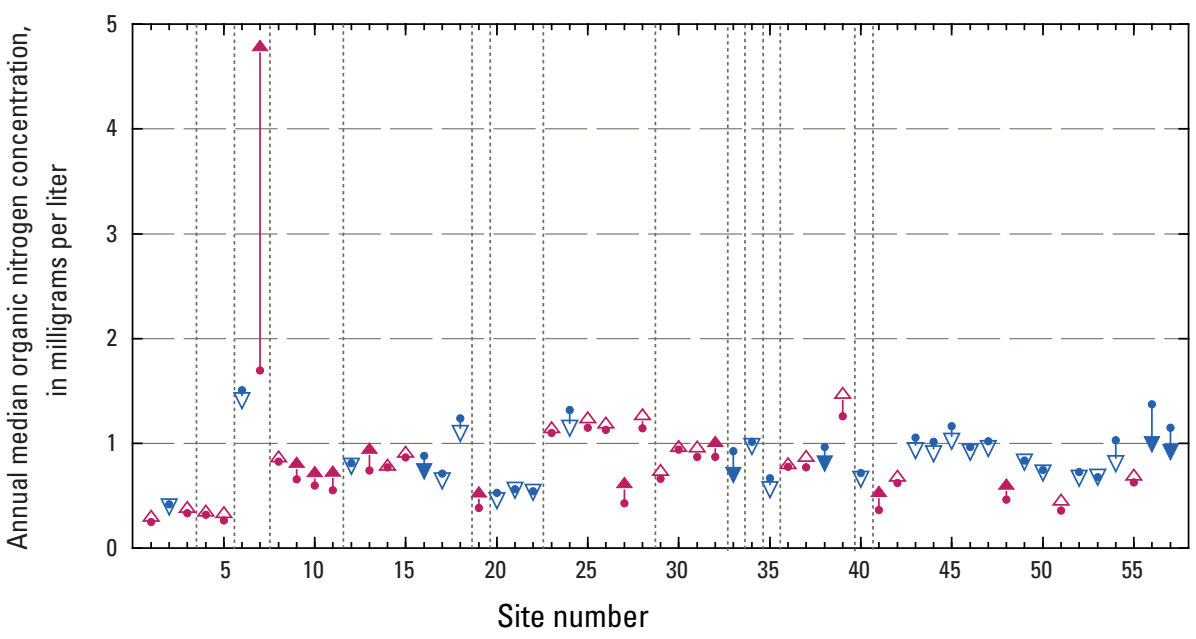

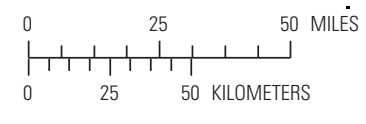

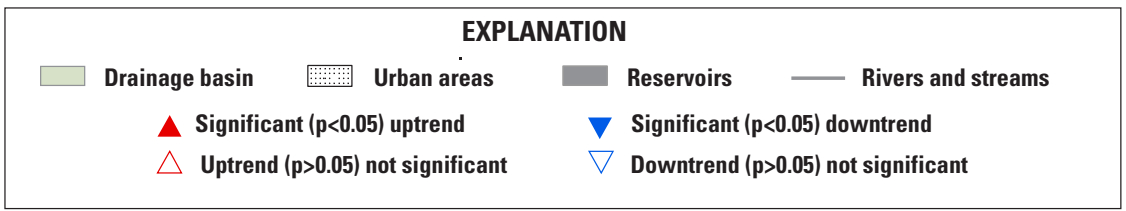

Figure 1-2. Significant and non-significant trends in organic nitrogen at 57 stream sites in Indiana, 2000-10. 
A

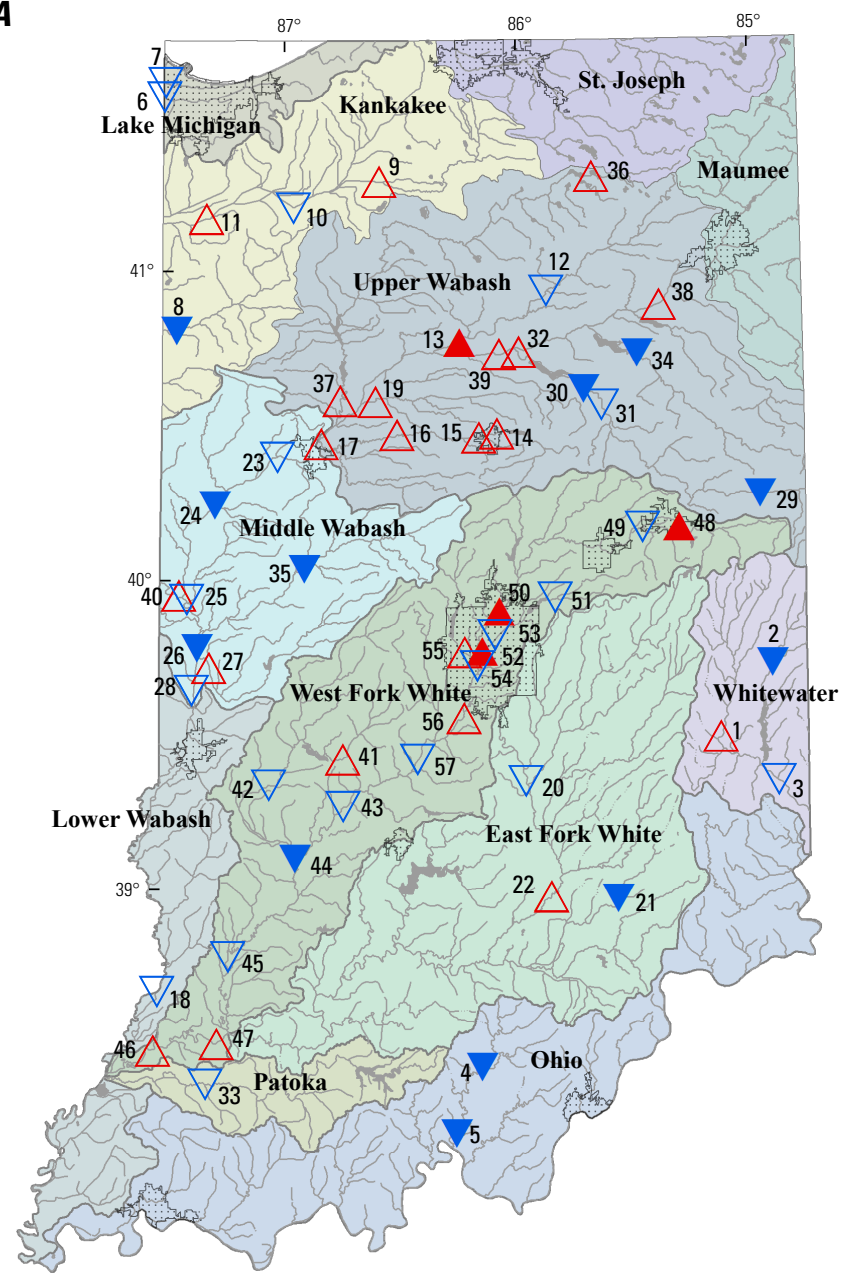

B

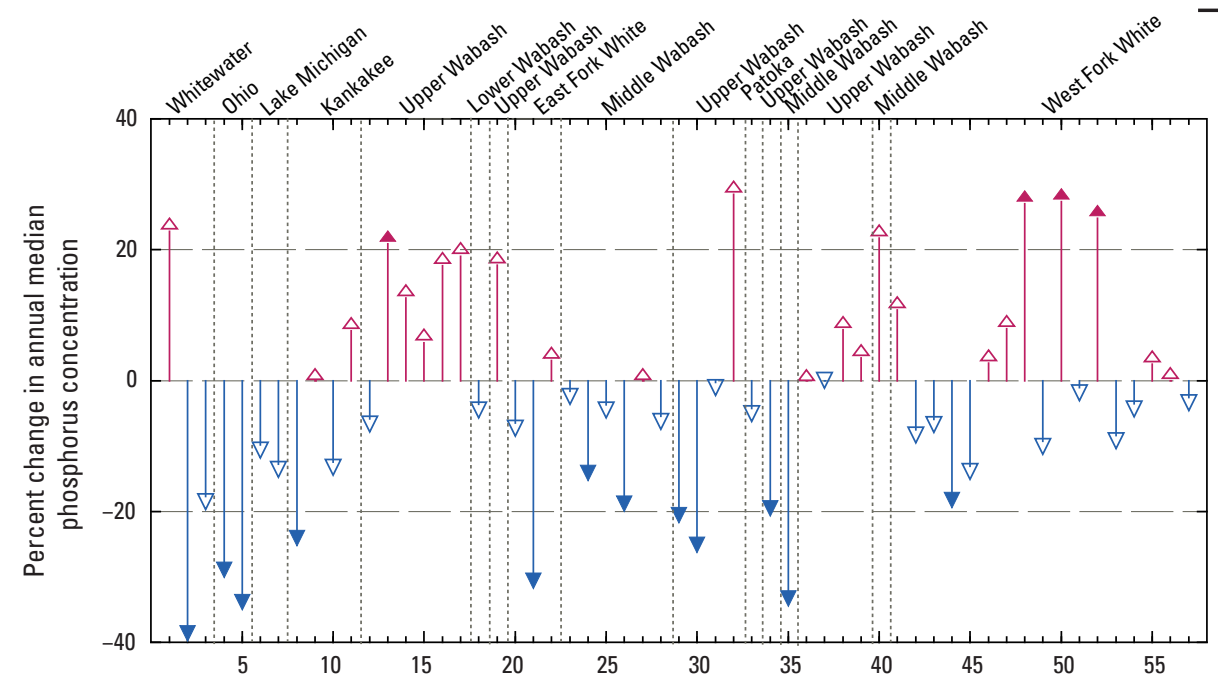

c

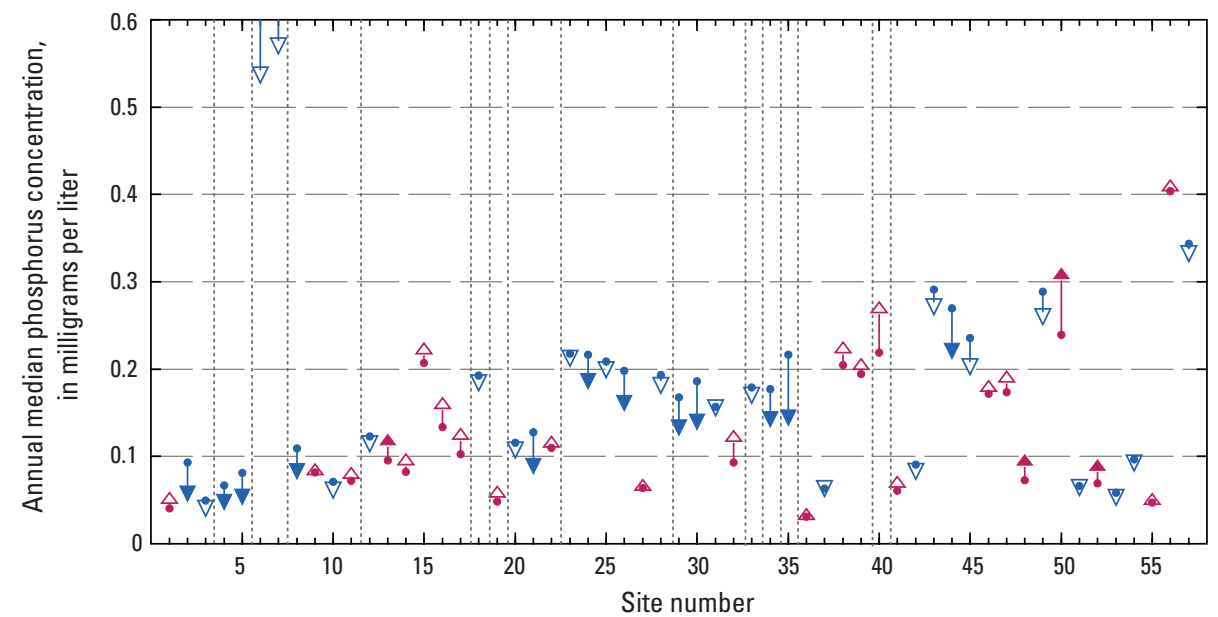

EXPLANATION

Figure 1-3. Significant and non-significant trends in phosphorus at 57 stream sites in Indiana, 2000-10. 
$\boldsymbol{A}$

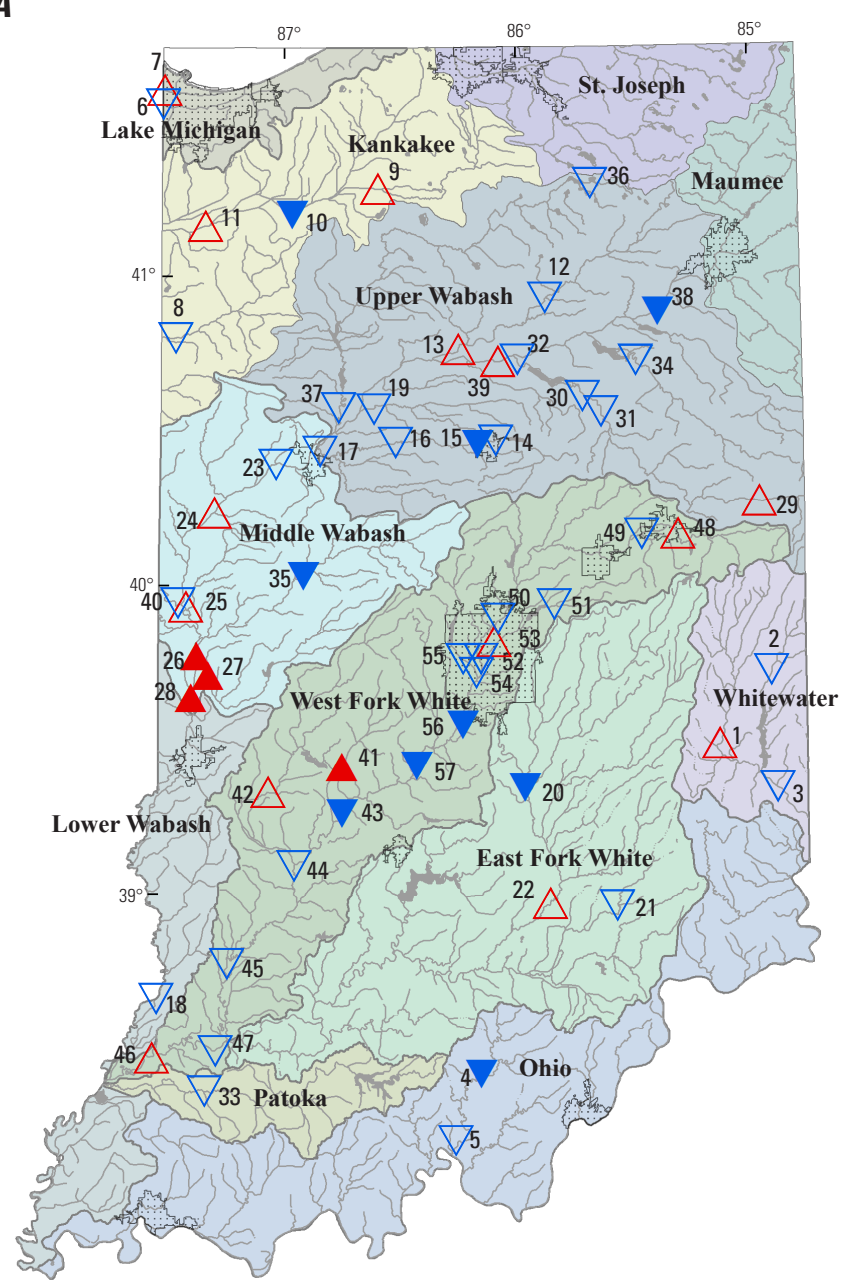

$B$

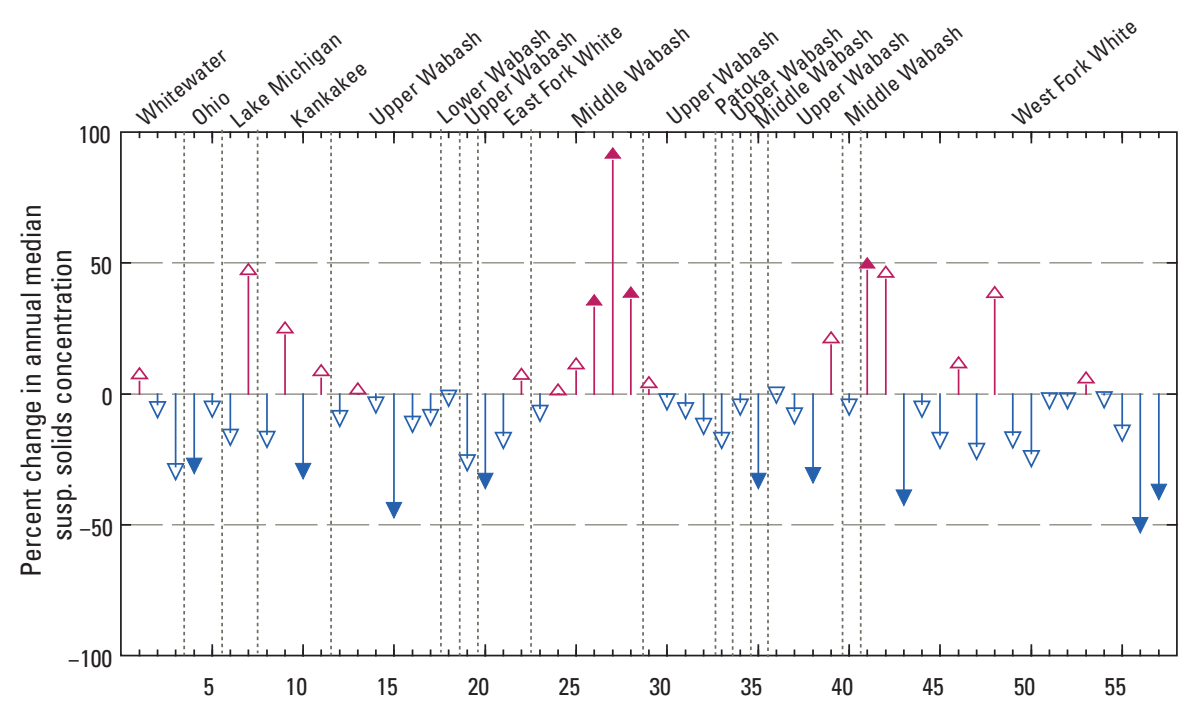

C

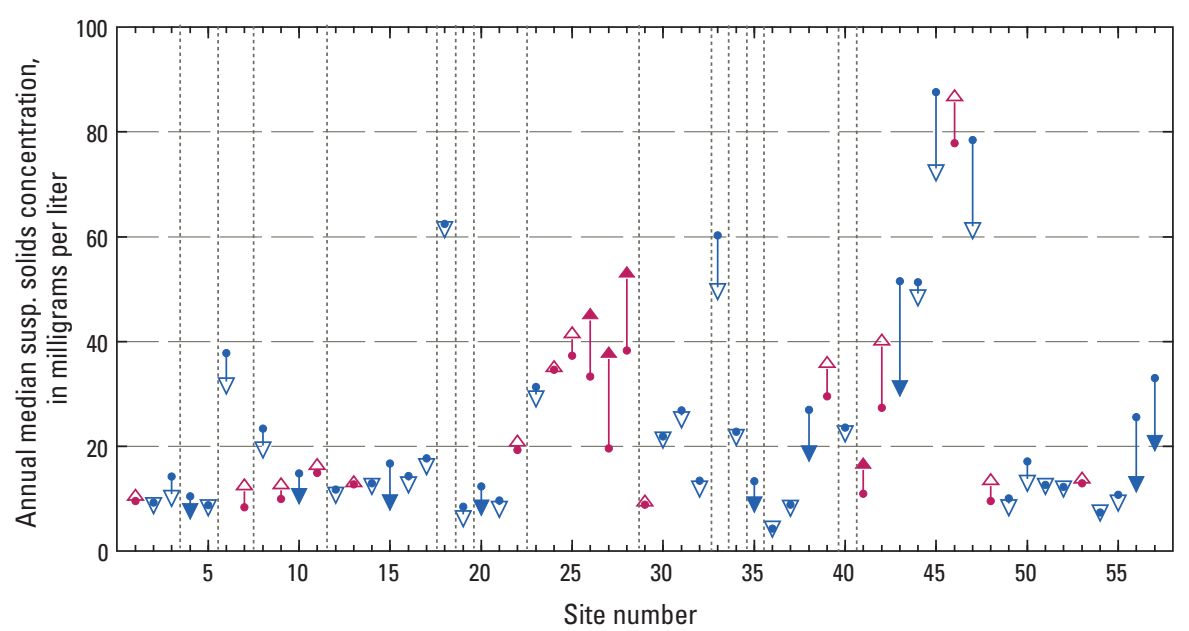

\section{EXPLANATION}

$\Delta$ Significant $(\mathrm{p}<0.05)$ uptrend

$\Delta$ Significant $(p<0.05)$ uptrend
$\triangle$ Uptrend $(p>0.05)$ not significant

$\nabla$ Significant $(\mathrm{p}<0.05)$ downtrend

$\nabla$ Downtrend $(\mathrm{p}>0.05)$ not significant

Figure 1-4. Significant and non-significant trends in suspended solids at 57 stream sites in Indiana, 2000-10. 
$\boldsymbol{A}$

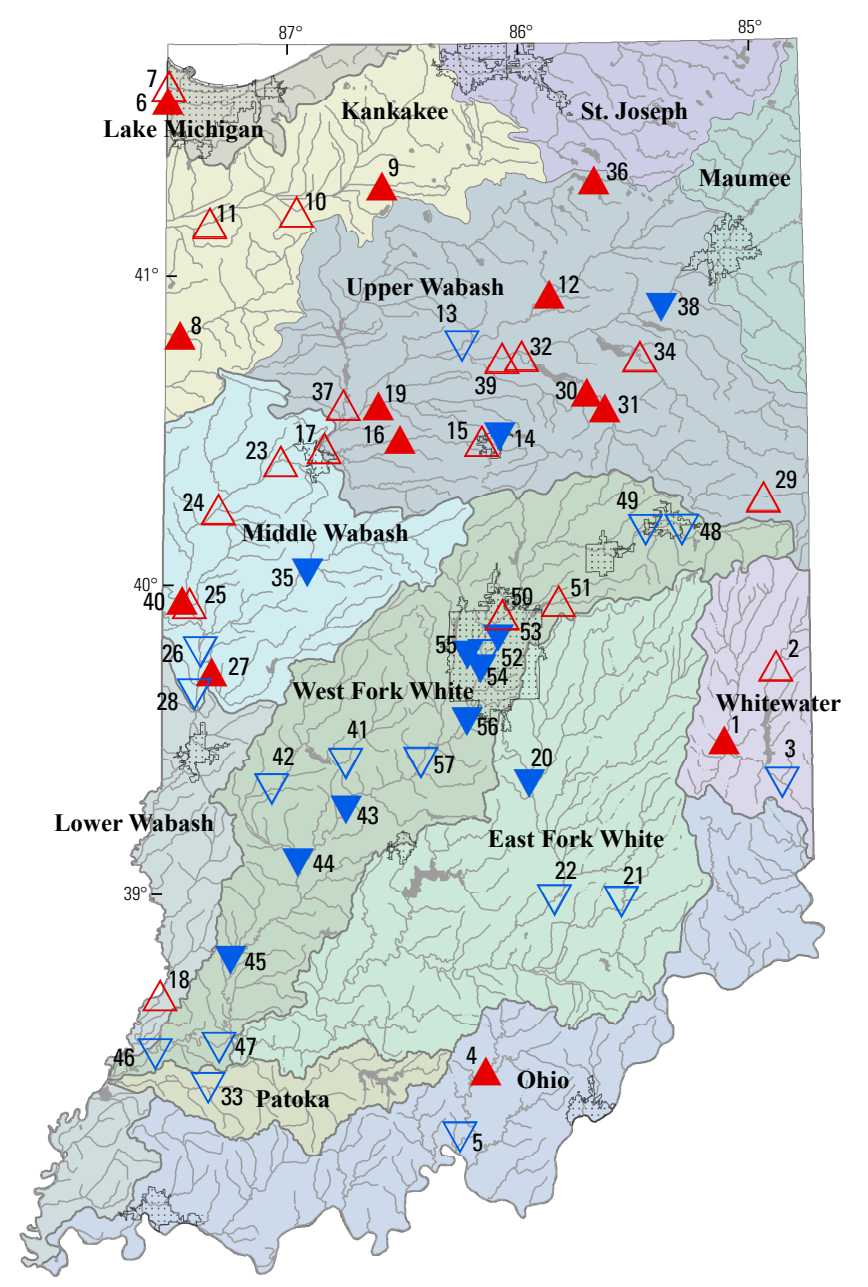

B

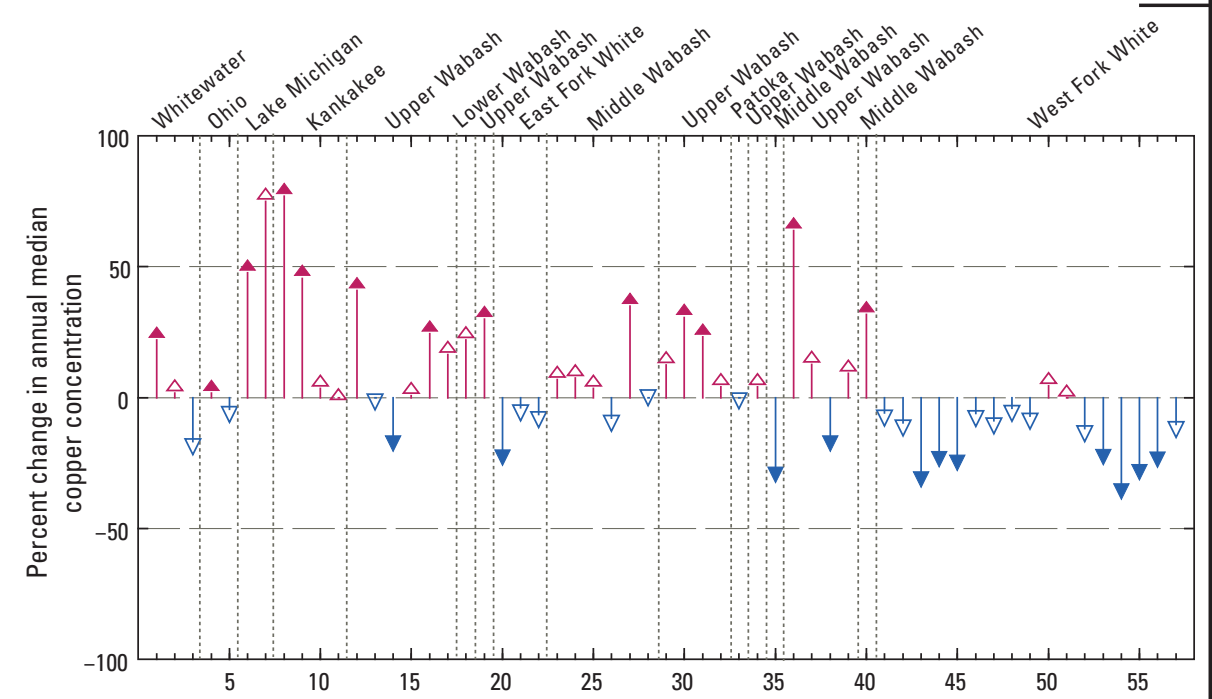

c

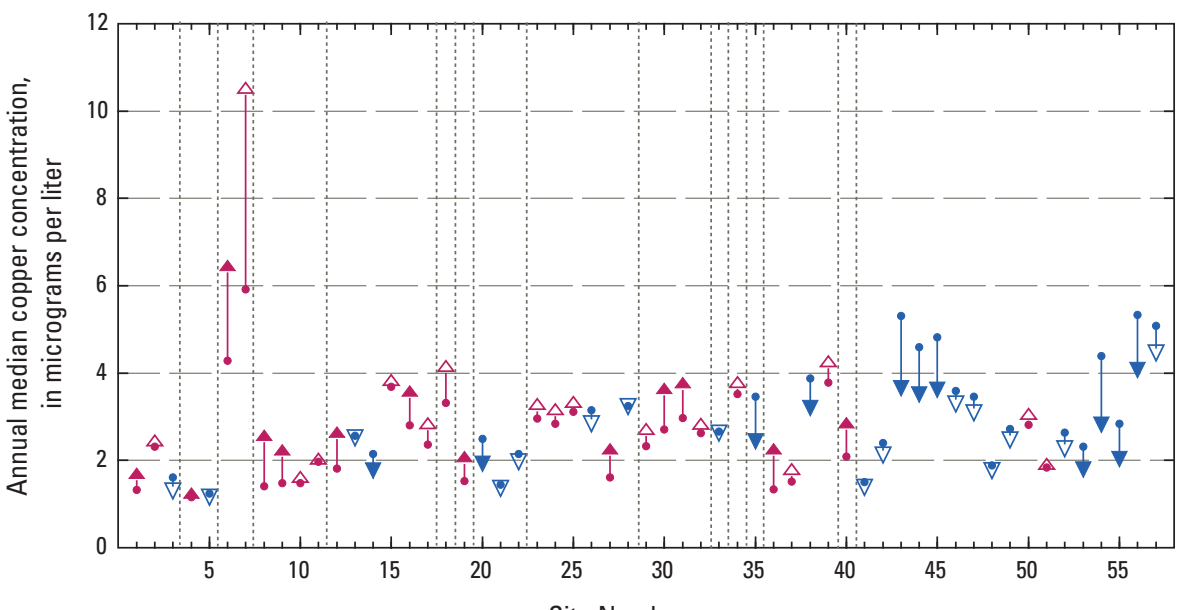

$\overbrace{0}^{0}$

EXPLANATION

$\square$ Drainage basin Wrin Urban areas $\square$ Reservoirs $\quad$ Rivers and streams

$\triangle$ Significant $(\mathrm{p}<0.05)$ uptrend

$\nabla$ Significant $(p<0.05)$ downtrend

$\triangle$ Uptrend ( $p>0.05)$ not significant $\quad \nabla$ Downtrend $(p>0.05)$ not significant

Figure 1-5. Significant and non-significant trends in copper at 57 stream sites in Indiana, 2000-10. 
$\boldsymbol{A}$

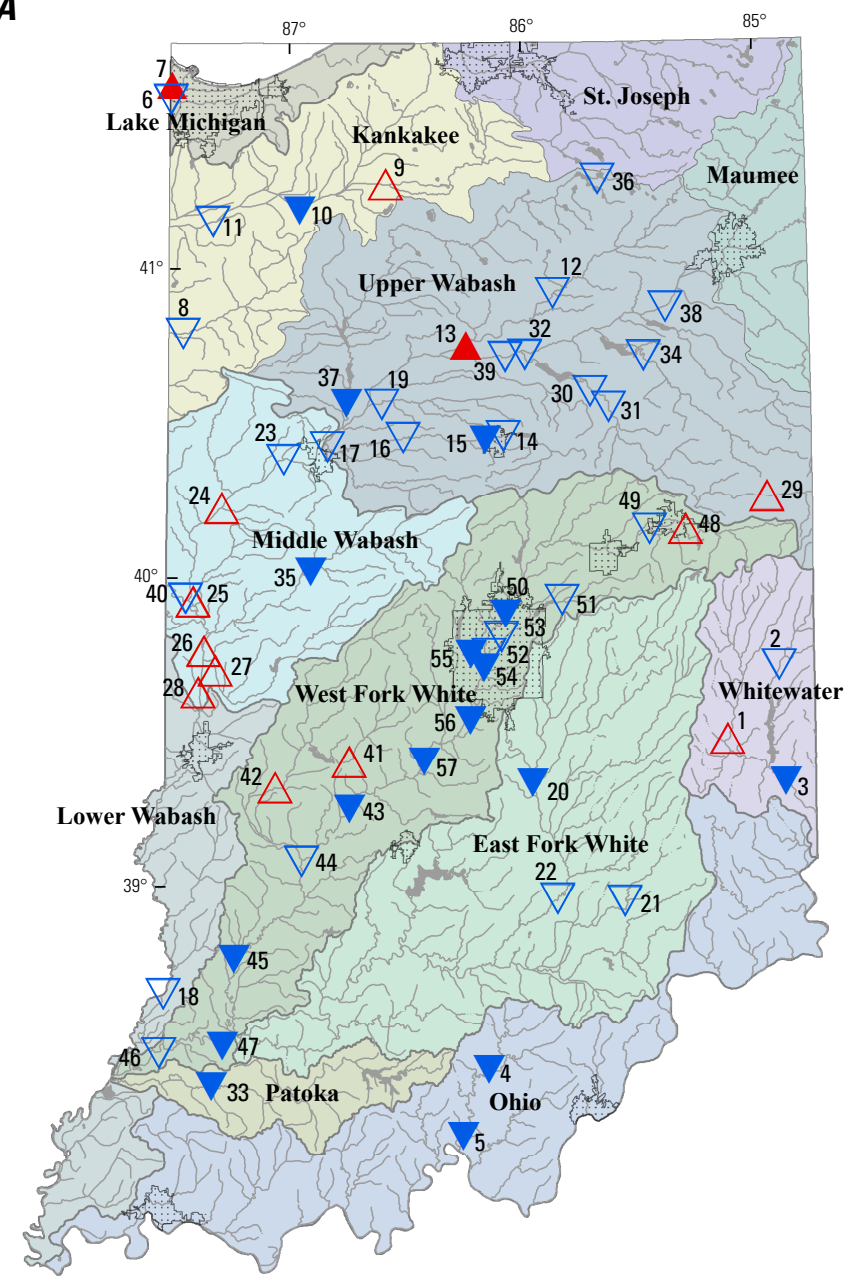

B

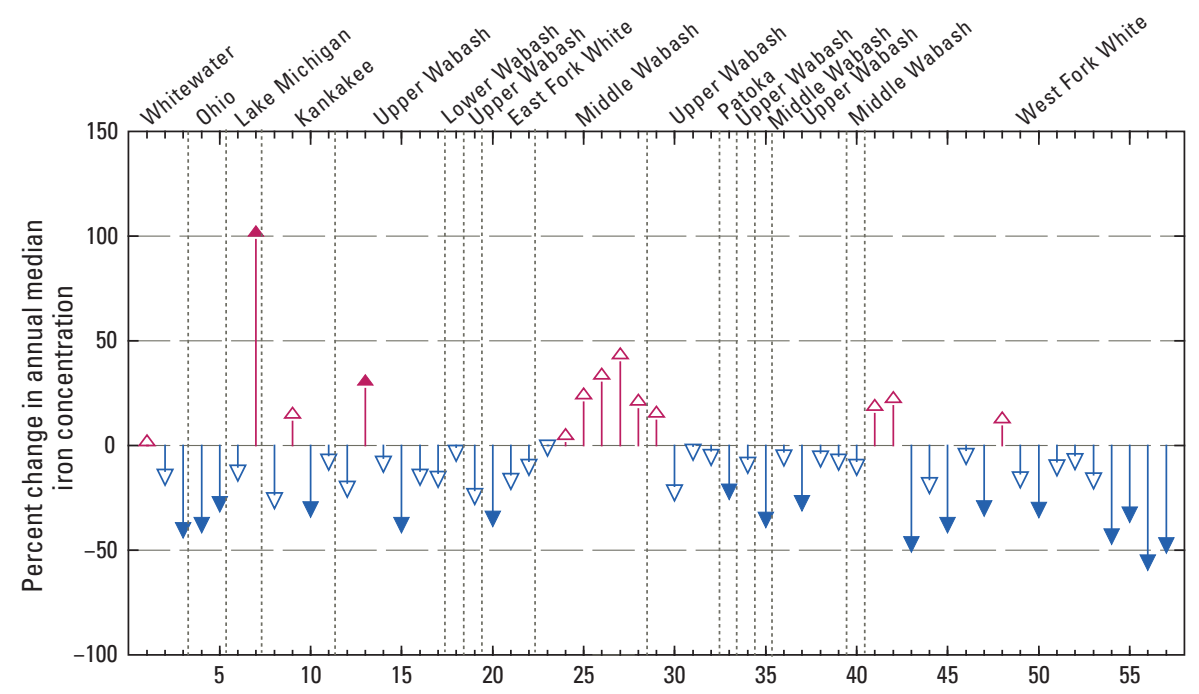

C

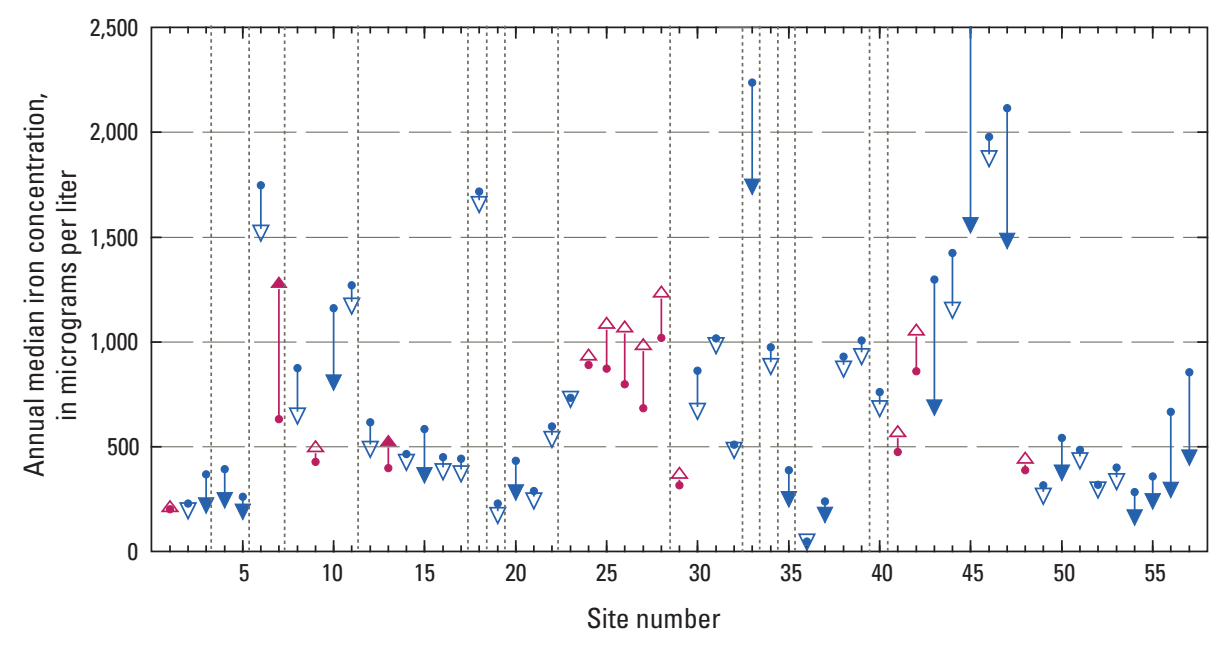

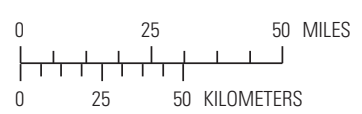

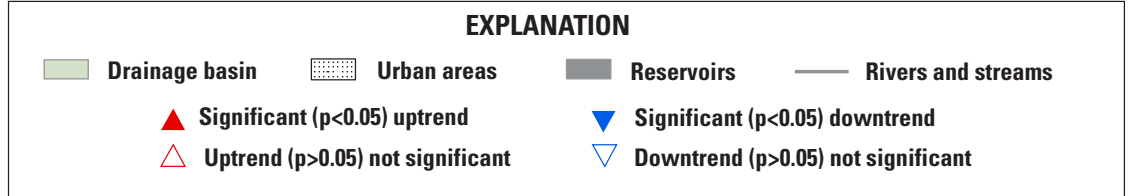

Significant $(p<0.05)$ uptrend

$\checkmark$ Significant $(\mathrm{p}<0.05)$ downtrend

$\nabla$ Downtrend ( $p>0.05)$ not significant

\section{XPLANATION}

Figure 1-6. Significant and non-significant trends in iron at 57 stream sites in Indiana, 2000-10. 
$\boldsymbol{A}$

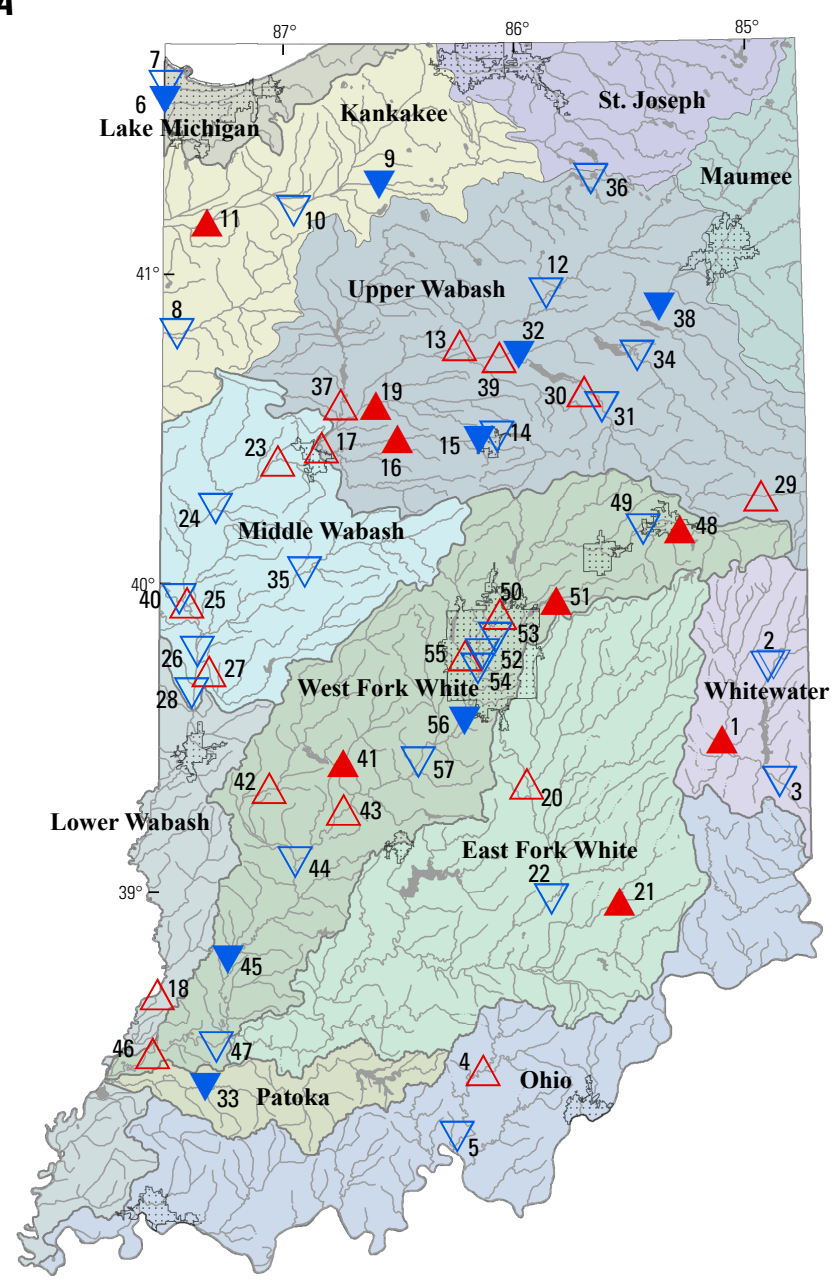

B

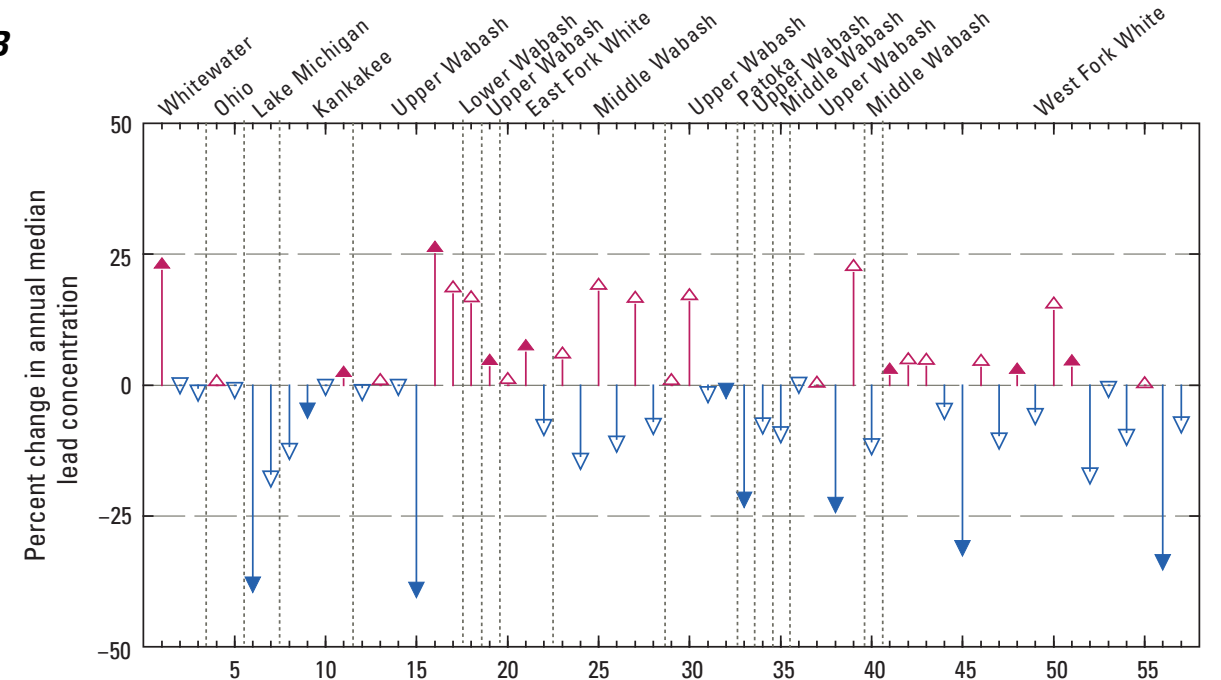

C

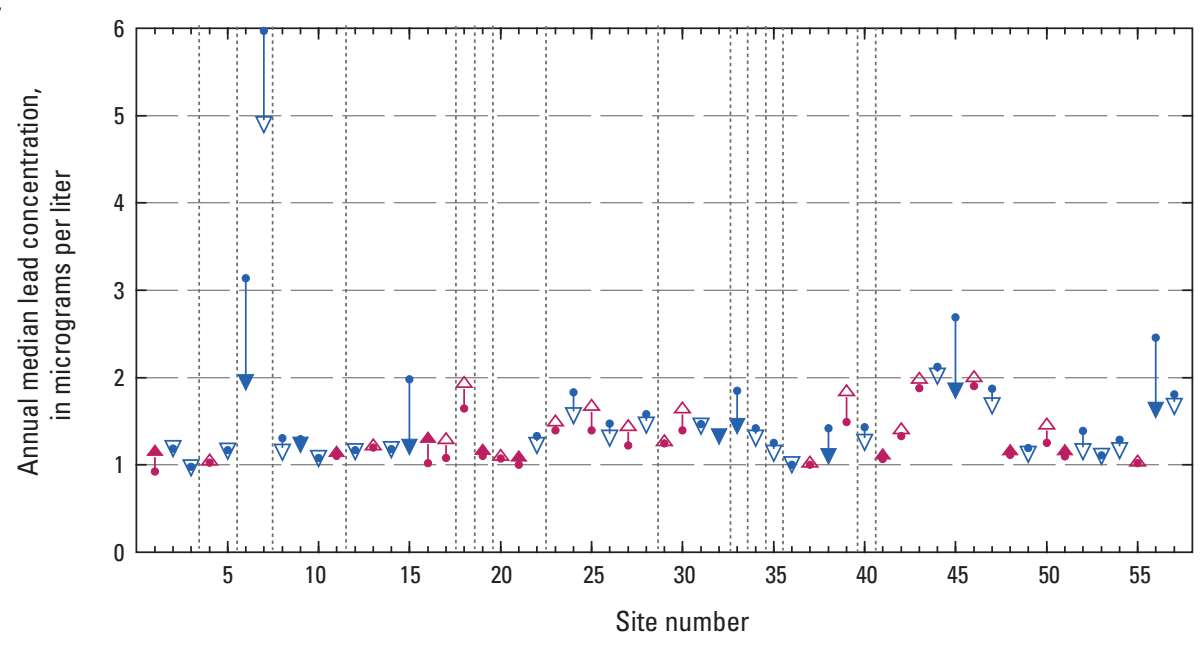

EXPLANATION

$\Delta$ Significant $(\mathrm{p}<0.05)$ uptrend

$\triangle$ Uptrend $(p>0.05)$ not significant

$\nabla$ Significant $(p<0.05)$ downtrend

$\nabla$ Downtrend $(p>0.05)$ not significant

Figure 1-7. Significant and non-significant trends in lead at 57 stream sites in Indiana, 2000-10. 
A

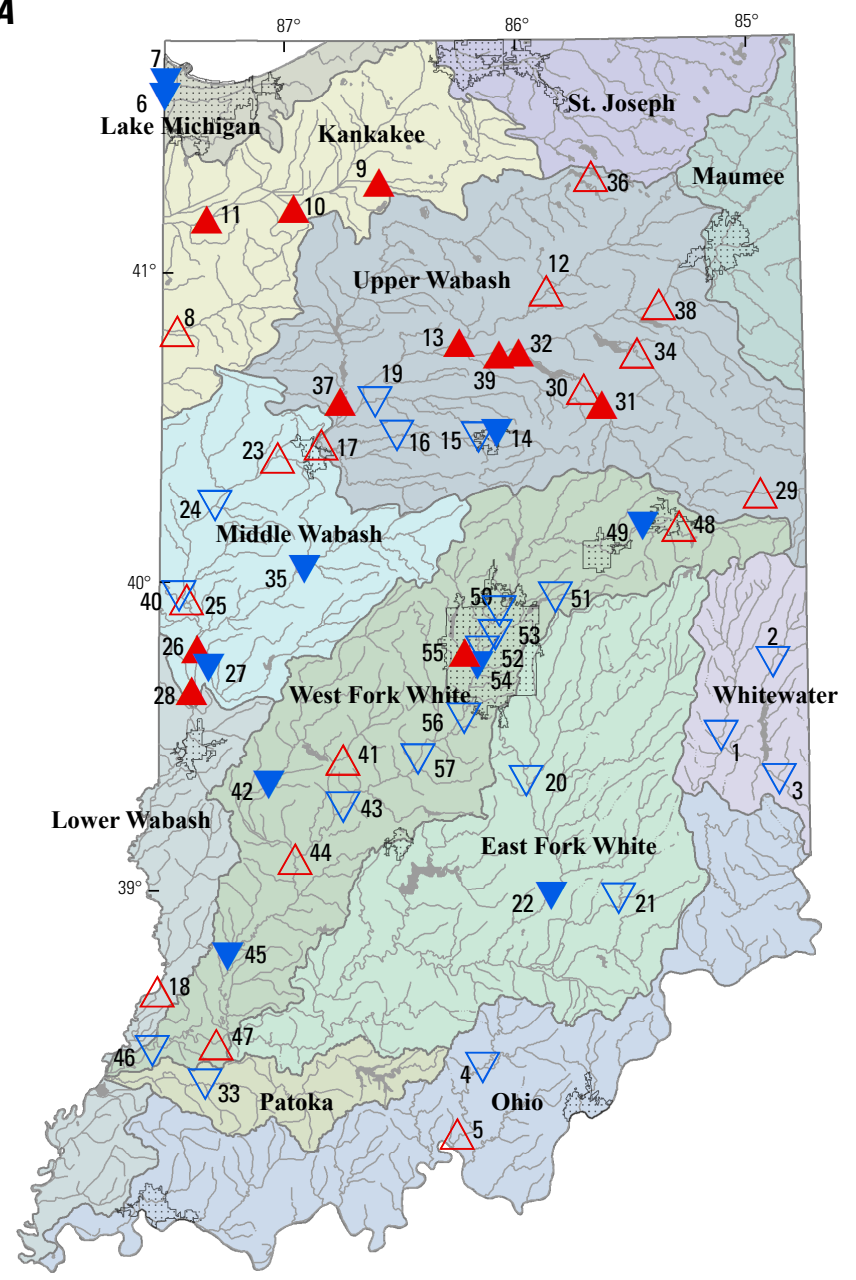

$\boldsymbol{B}$

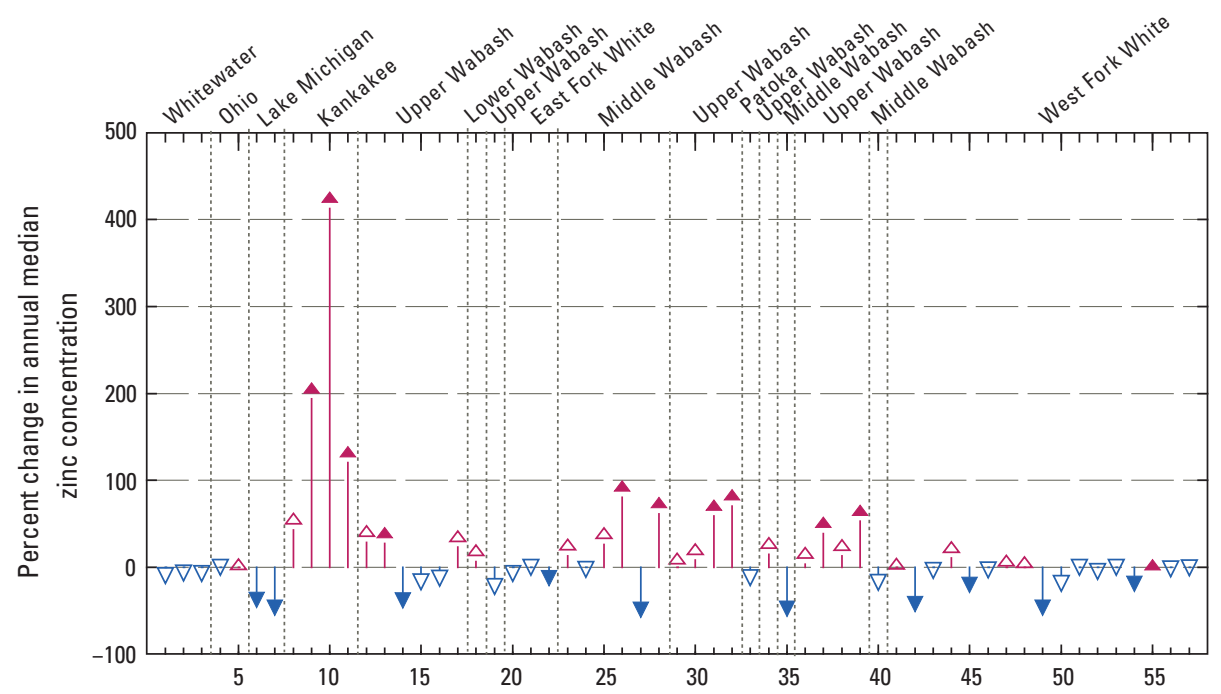

$\boldsymbol{C}$

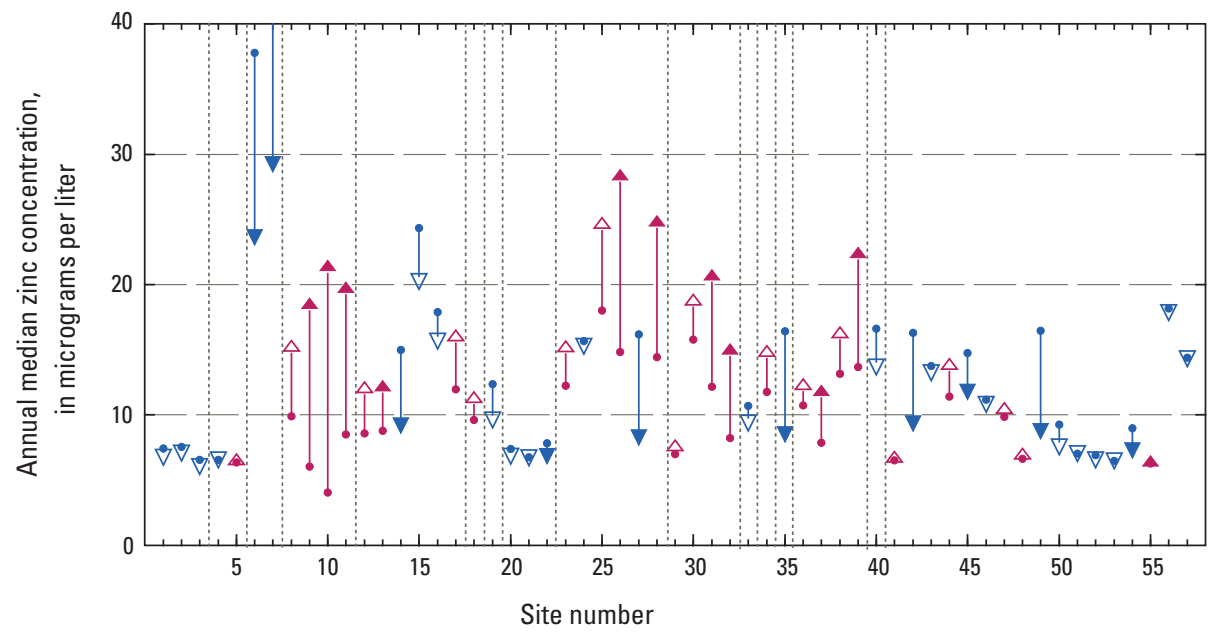

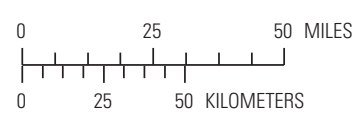

\begin{tabular}{|c|c|}
\hline \multicolumn{2}{|c|}{ EXPLANATION } \\
Drainage basin $\quad$ Urban areas & Reservoirs $\quad$ Rivers and streams \\
$\Delta$ Significant $(\mathrm{p}<0.05)$ uptrend & $\nabla$ Significant $(\mathrm{p}<0.05)$ downtrend \\
$\triangle$ Uptrend $(\mathrm{p}>0.05)$ not significant & $\nabla$ Downtrend $(\mathrm{p}>0.05)$ not significant \\
\hline
\end{tabular}

Figure 1-8. Significant and non-significant trends in zinc at 57 stream sites in Indiana, 2000-10. 
$\boldsymbol{A}$

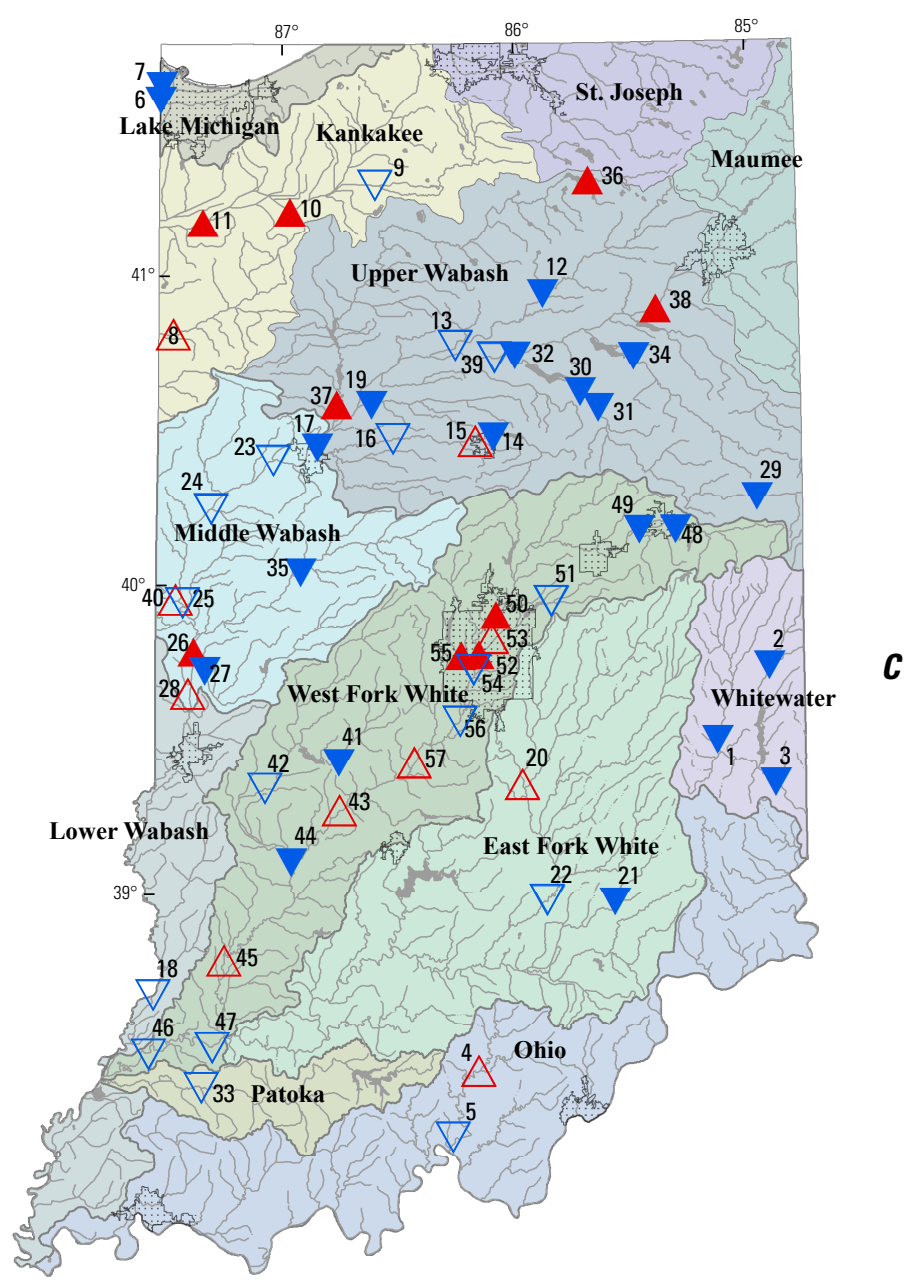

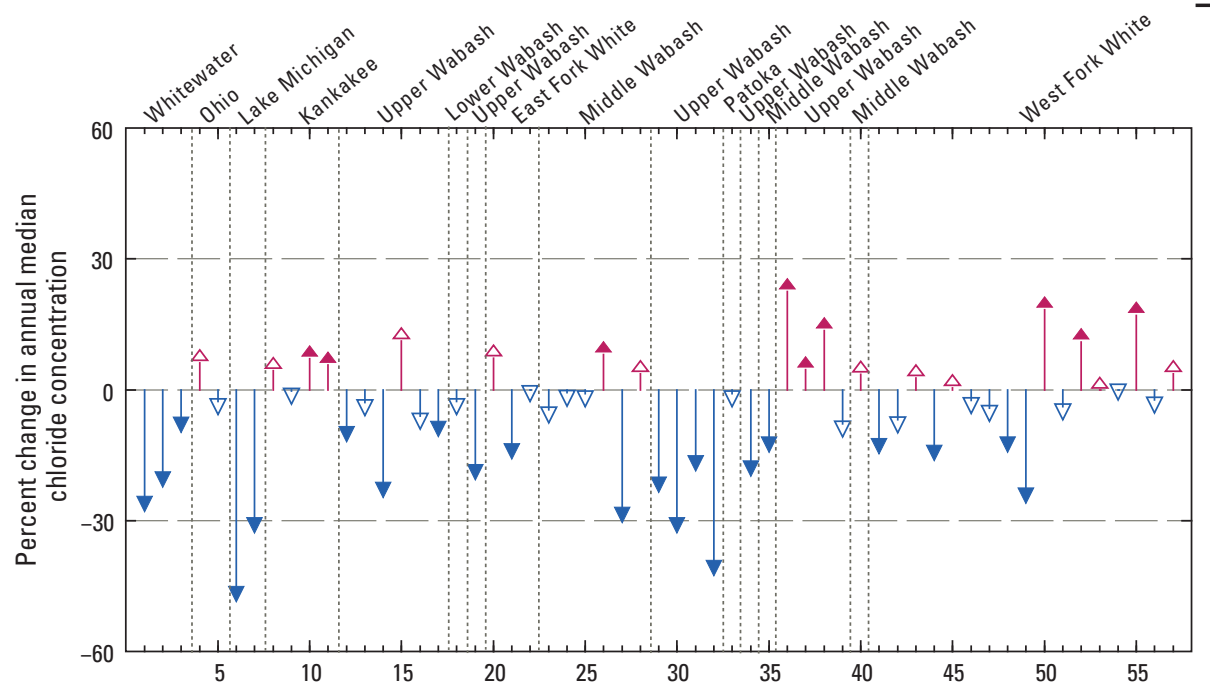

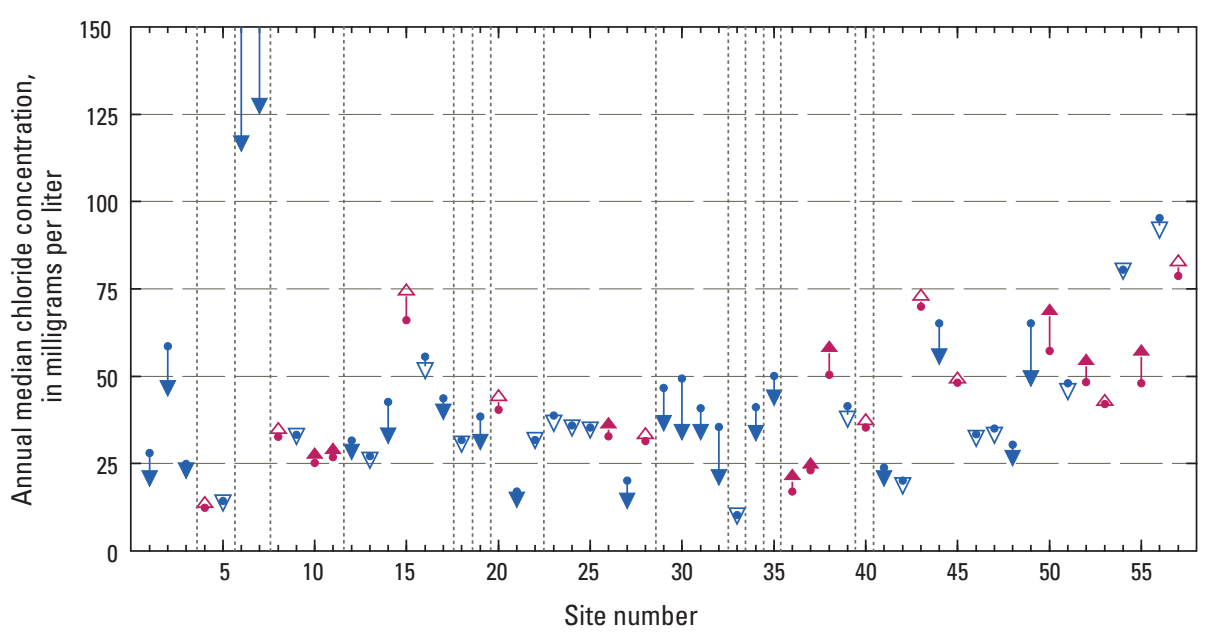

EXPLANATION

Reservoirs _ Rivers and streams

$\nabla$ Significant $(p<0.05)$ downtrend

$\nabla$ Downtrend (p>0.05) not significant

Figure 1-9. Significant and non-significant trends in chloride at 57 stream sites in Indiana, 2000-10. 
$\boldsymbol{A}$

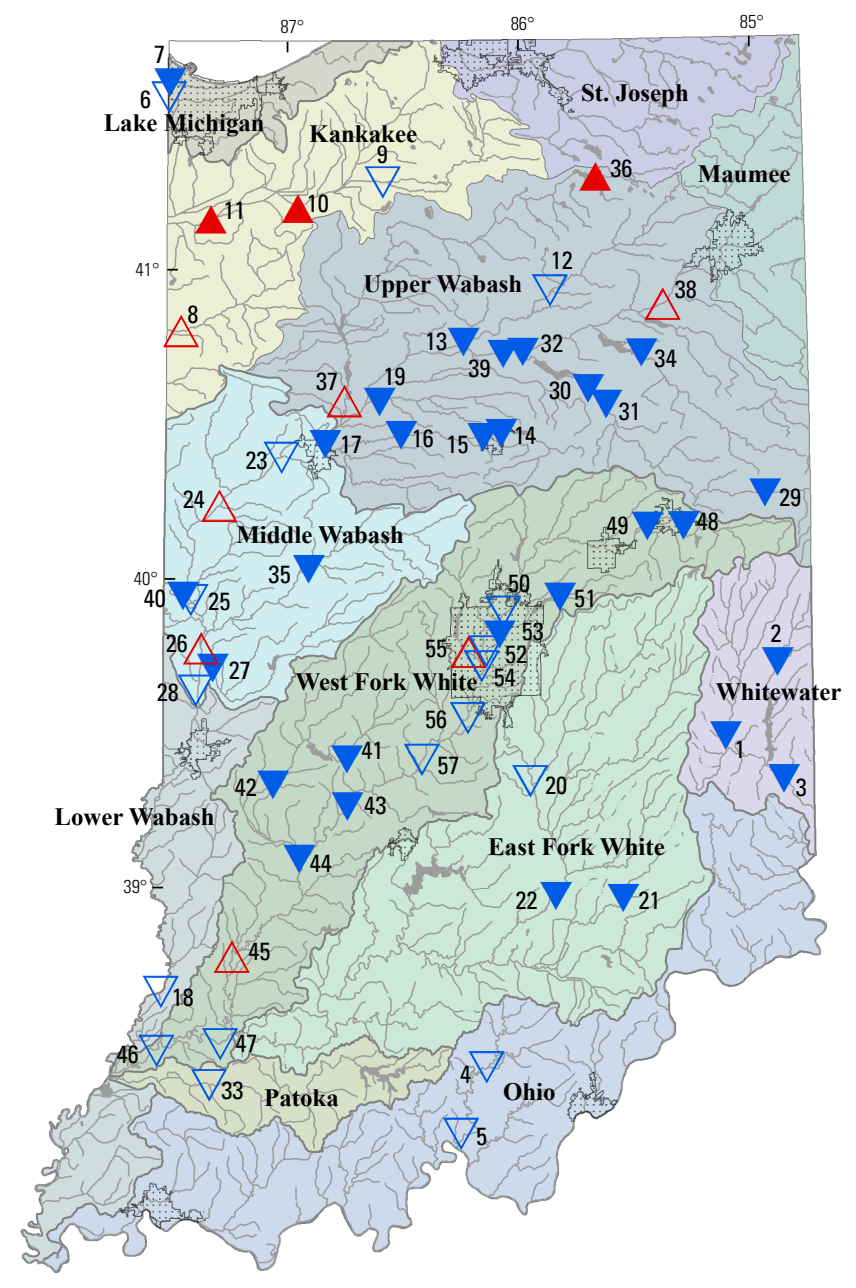

B
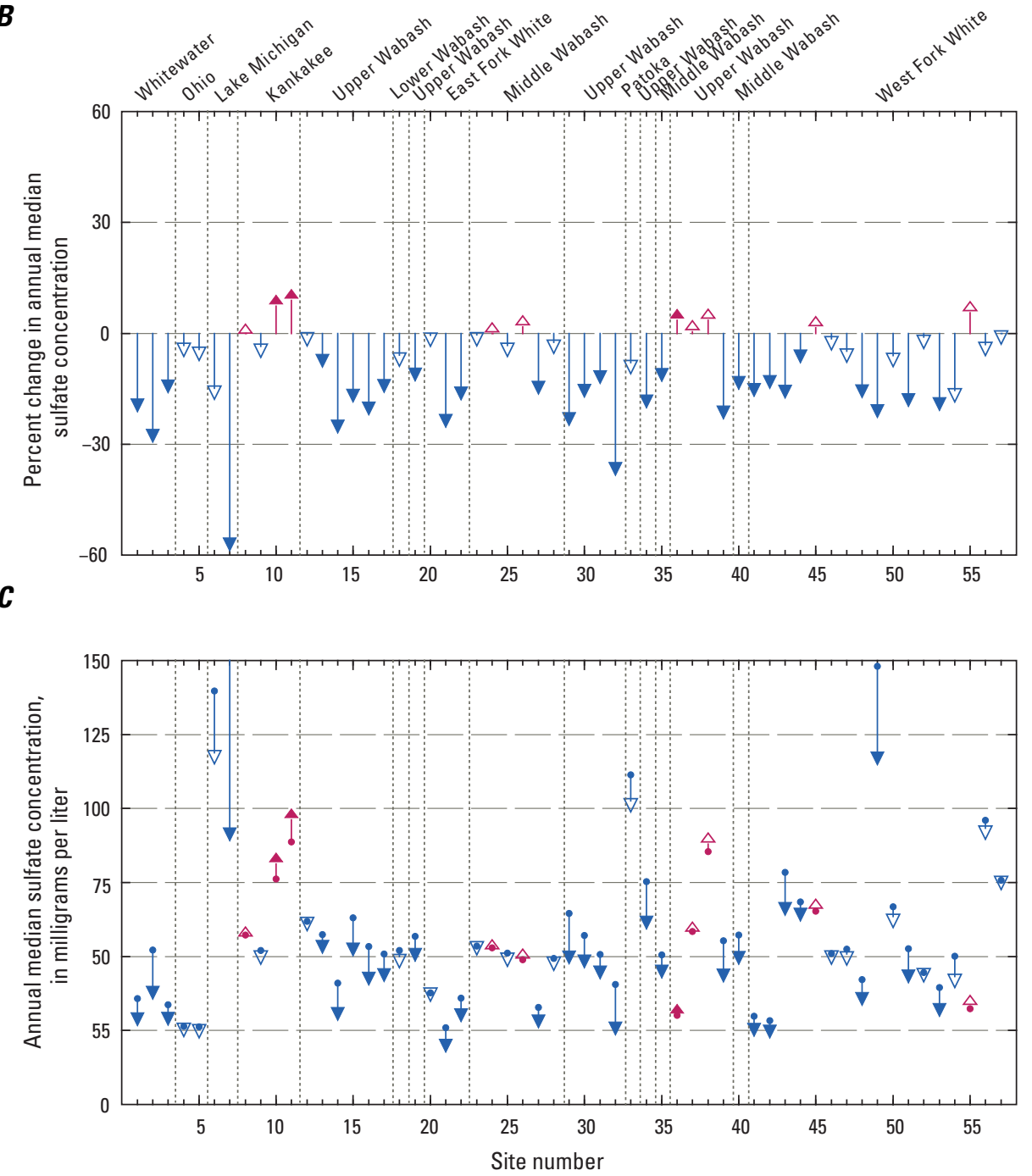

EXPLANATION

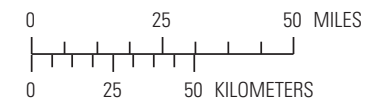

\begin{tabular}{|c|c|}
\hline \multicolumn{2}{|c|}{ EXPLANATION } \\
$\square$ Drainage basin $\quad$ Urban areas & Reservoirs $\quad$ Rivers and streams \\
$\Delta$ Significant $(\mathrm{p}<0.05)$ uptrend & $\nabla$ Significant $(\mathrm{p}<0.05)$ downtrend \\
$\triangle$ Uptrend $(\mathrm{p}>0.05)$ not significant & $\nabla$ Downtrend $(\mathrm{p}>0.05)$ not significant \\
\hline
\end{tabular}

Figure 1-10. Significant and non-significant trends in sulfate at 57 stream sites in Indiana, 2000-10. 
$\boldsymbol{A}$

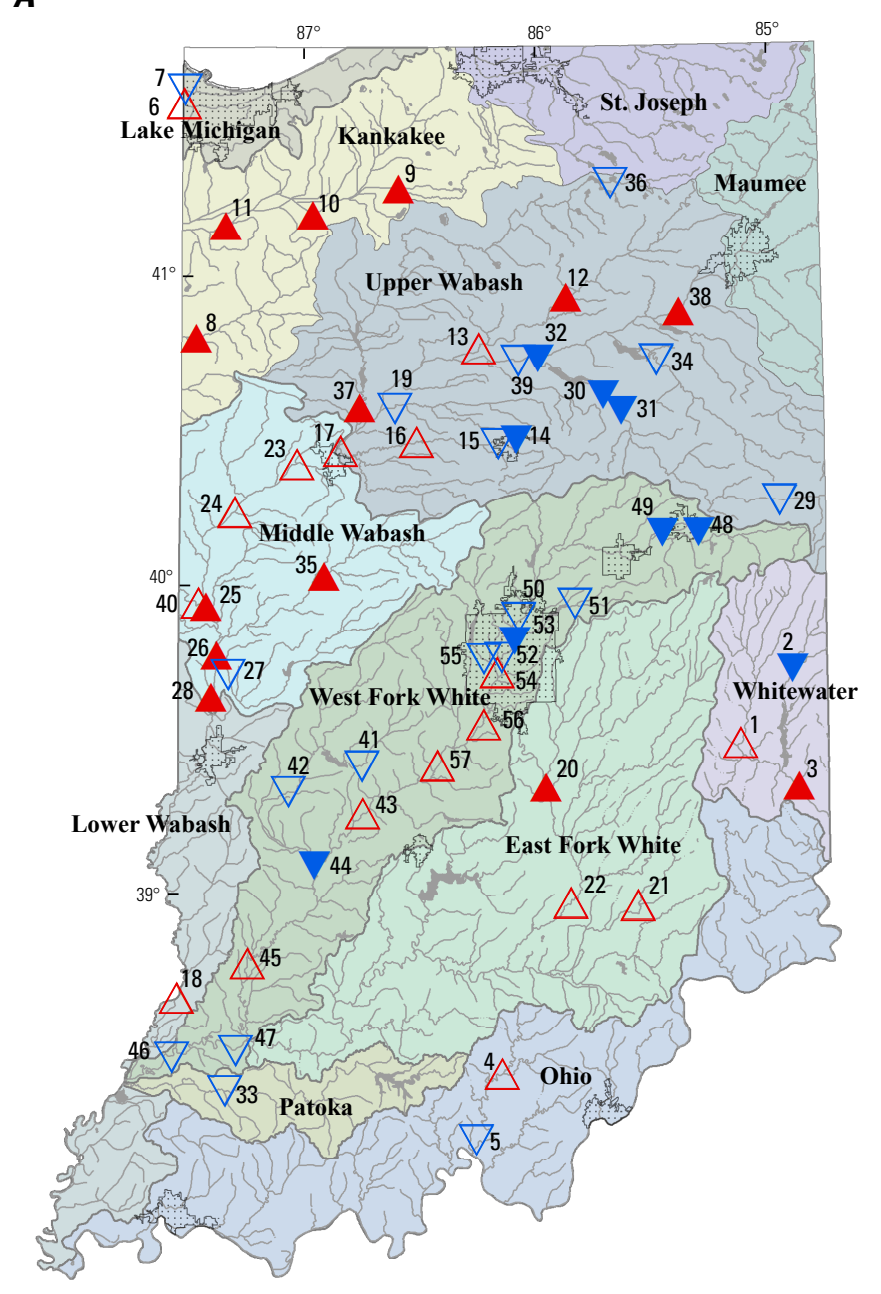

$\boldsymbol{B}$

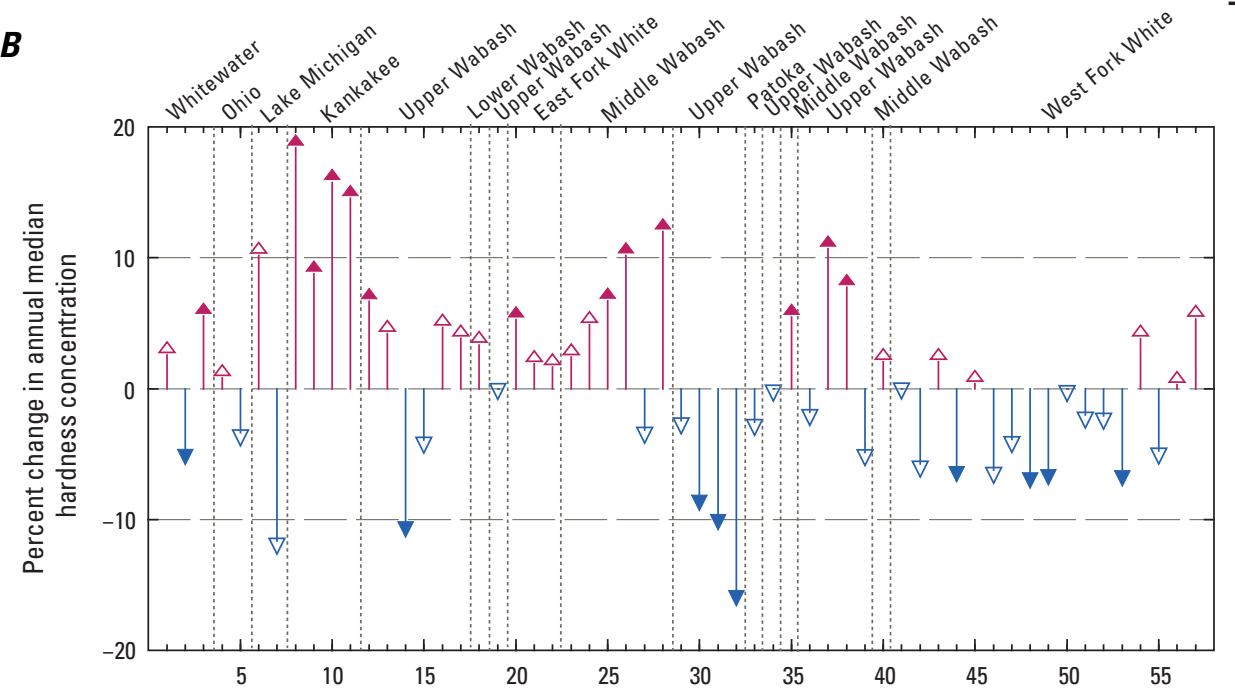

C

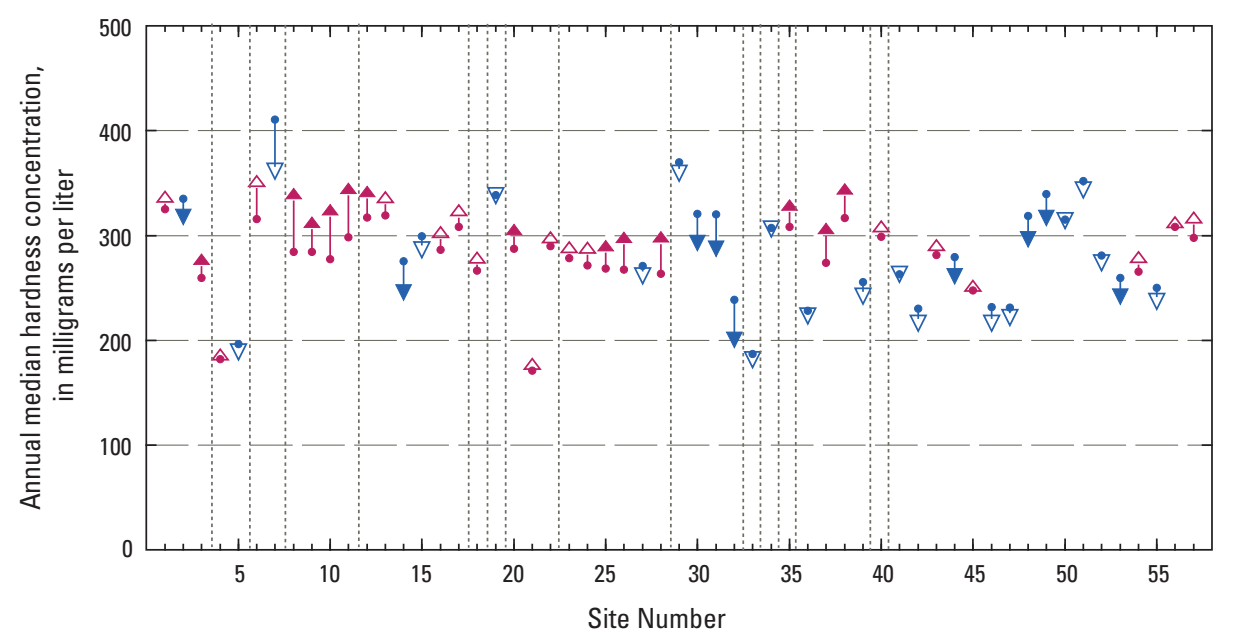

\section{EXPLANATION}

Significant $(p<0.05)$ downtrend

$\triangle$ Uptrend $(\mathrm{p}>0.05)$ not significant $\quad \nabla$ Downtrend $(\mathrm{p}>0.05)$ not significant

Figure 1-11. Significant and non-significant trends in hardness at 57 stream sites in Indiana, 2000-10. 
$\boldsymbol{A}$

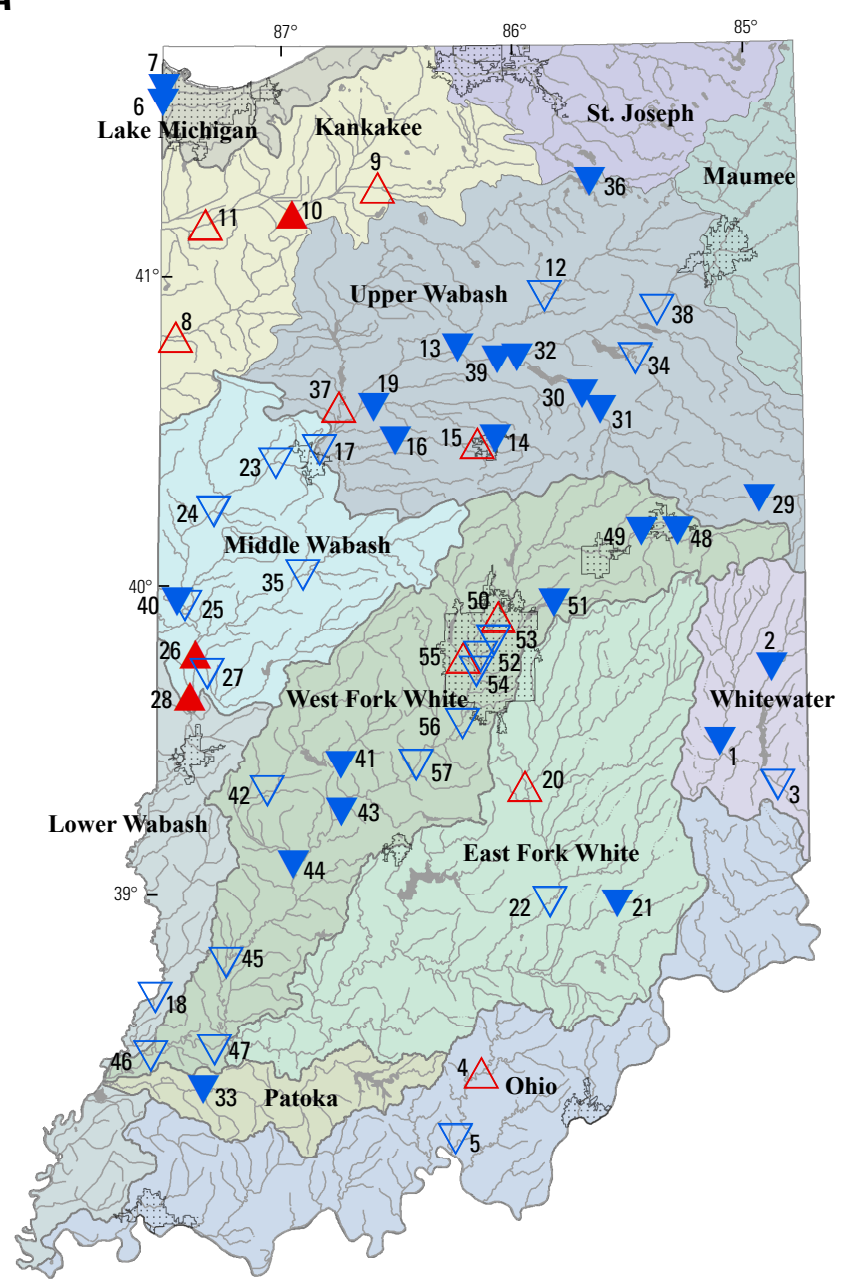

B

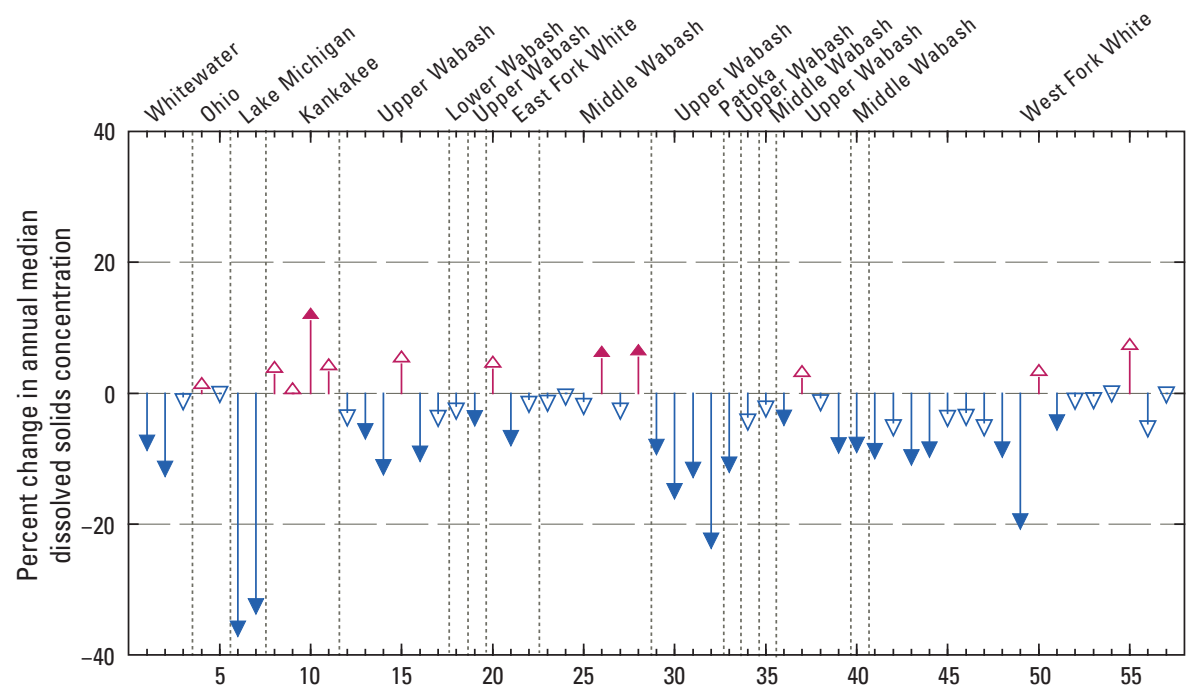

c

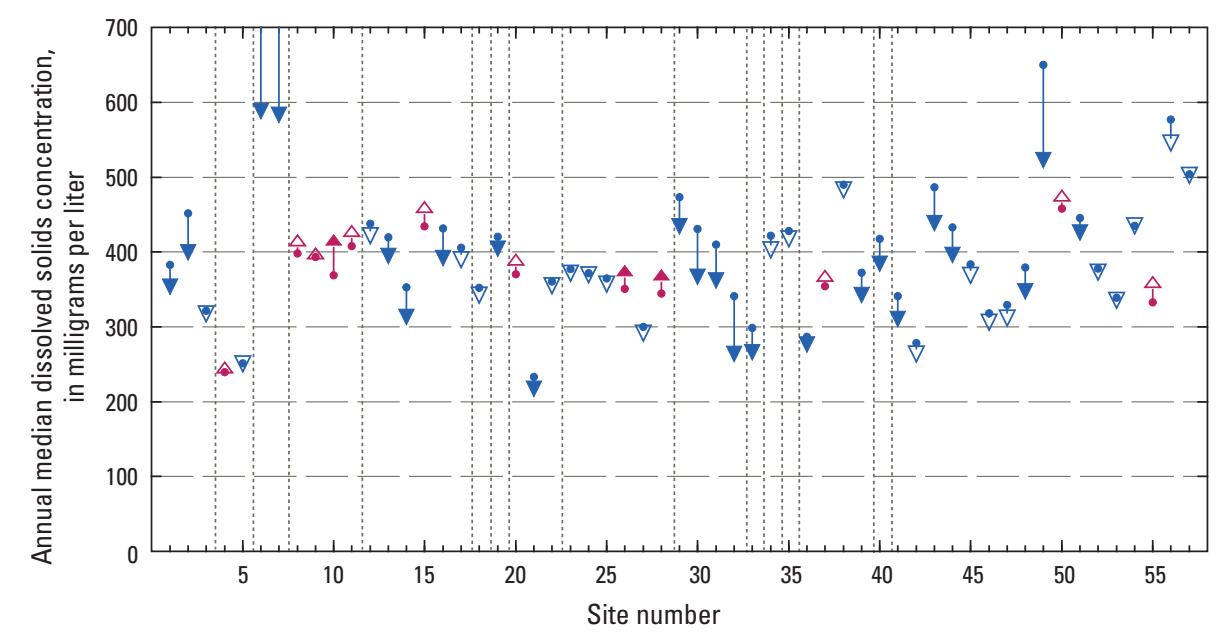

EXPLANATION

Figure 1-12. Significant and non-significant trends in dissolved solids at 57 stream sites in Indiana, 2000-10. 

Publication services provided by the U.S. Geological Survey Science Publishing Network Columbus Publishing Service Center

For more information concerning the research in this report contact the

Director, Indiana Water Science Center

U.S. Geological Survey

5957 Lakeside Boulevard

Indianapolis, IN 46278-0000

http://in.water.usgs.gov/ 
